\title{
BIOLOGIA, NUTRIÇÃO QUANTITATIVA E DANOS CAUSADOS POR Spodoptera frugiperda (J. E. SMITH, 1797) (LEPIDOPTERA: NOCTUIDAE) EM MILHO CULTIVADO EM SOLO CORRIGIDO PARA TRÊS NIVEIS DE ALUMÍNIO
}

\author{
LENITA JACOB OLIVEIRA \\ Engenheira Agrônoma
}

Orientador: Prof. Dr. JOSÉ ROBERTO POSTALI PARRA

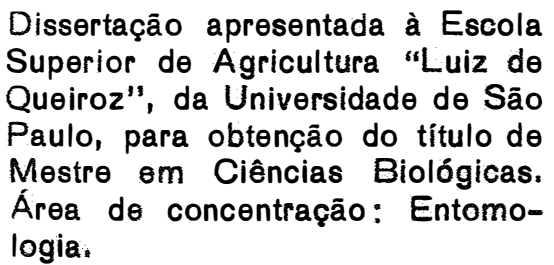

PIRACICABA

Estado de São Paulo - Brasil

Fovereiro - 1987 


\section{AGRADECIMENTOS}

A. Empresa Brasileira de Pesquisa Agropecuária (EMBRAPA) e ao Centro Nacional de P'esquisa de Mitho e Sorgo (CNPMS), por terem cedido toda infraestrutura ne necessāria à realização deste trabalho.

A Divisão de Defensivos Agrícolas e aos pesquisadores da Seção de Praguicidas do Instituto Biológico de São Paulo, pela oportunidade dada para frequentar o curso de Pós-Graduação e pelo apoio recebido.

Ao Departamento de Entomologia da Escola Superior de Agricultura "Luiz de Queiroz", incluindo professores e funcionärios, pela assistência durante o Curso de Pós-Graduação.

Aos colegas e amigos do Curso de Pós-Gráduaça, pele convívio e oportunidade de intercâmbio de Tderlas.

A todos os funcionários e amigos do CNPMS, nes pessoas do técnico de laboratório Gilberto Geraldo Sil va e do técnico agrícola Mauro Paulinelli, pelas colaborafões prestadas.

A Engạ Agrícola Rosimēri G. Gonçalves, pela ajuda na condução dos ensaios de laboratório.

Ao Dr. Carlos Alberto Vasconcellos, pesquisador do CNPMS, pela indispensável colaboraçäo nos assuntos relacionados à fertilidade do solo.

Agradecimentos especiais são devidos ao Prof. Dr. José R. Postali Parra do Departamento de Entomologia da ESALQ/USP, pela valiosa orientação e pela assistência e apoio durante o curso e ao Dr. Ivan Cruz, pes quisador do CNPMS, pela colaboraçãoem todas as fases deste estudo.

Enfim, agradecimentos a todos que direta ou indiretamente contribuíram para a realização deste trabalho. 
i i i.

\section{TNDICE}

Pàgina

LISTA DE FIGURAS ................ vi i

LISTA DE TABELAS ................. viii

RESUMO $\ldots \ldots \ldots \ldots \ldots \ldots \ldots \ldots \ldots \ldots \ldots \ldots \ldots \ldots \ldots \ldots \ldots \ldots \ldots \ldots$

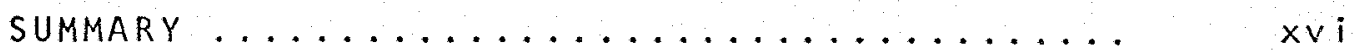

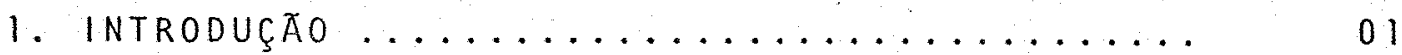

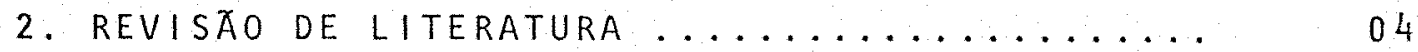

2.1. Biologia de spodoptera frugiperda (J.E. Smith, 1797) ................. 04

2.2. Wutrigao Quantitativa ........... 08

2.2.1. Influência de fatores bioecológ cos sobre a alimentação dos inse tos ................. 10

2.2.2. Consumo e utilização de alimento por spodoptera spp. ........

2.3. Efeito do Estado Nutricional da Plan-

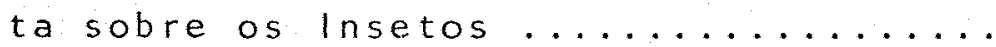

2.3.1. Efeito da fertilidade do solo e fertilizantes sobre insetos .... 2.3.1.1. Efeito da nutrição da plansobre os insetos sugadores.

2.3.1.2. Efeito da nutrição da planta sobre insetos mastigado-

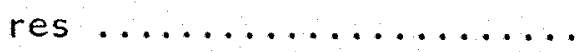

2.3.1.3. Efeito da nutrição da planta sobre Spodoptera spp...

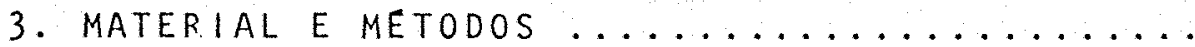

3.1. Efeito do Teor de Aluminio do Solo sobre os Danos Causados por $S$. frugiperda em Milho em Condiçōes de Campo ...... 3.1.1. Análise e obtenção dos diferentes teores de alumínio do solo ..... 
Pàgina

3.1.2. obtenção dos niveis de infestação da cultura por $S$. frugiperda ....

3.1.3. Delineamento experimental e condu

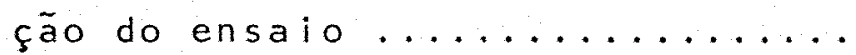

3.1.4. Avaliação da interação entre teor de alumínio do solo e danos causa dos por $S$. frugiperda .........

3.2. Efeito do Teor de aluminio do Solo sobre a Seleção do Milho como Hospedeiro por S. frugiperda $\ldots \ldots \ldots \ldots \ldots \ldots \ldots$

3.3. Efeito do Teor de Alumínio do Solo sobre a Biologia e Nutrição Quantitativa de $S$. frugiperda em Milho em Condições de Labo

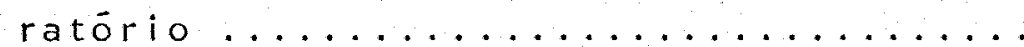
44

3.3.1. Biologia comparada ...........

3.3.2. Tabela de vida de fertilidade ... 45

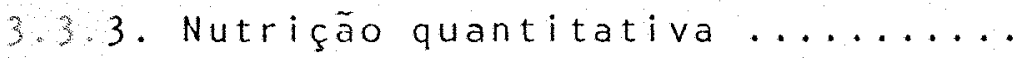

3.3 .3 .2 . Tndices nutricionais ...

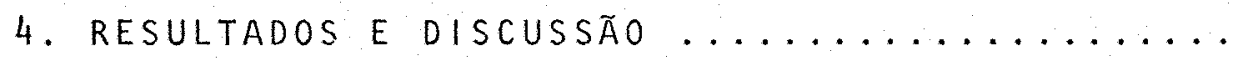

4.1. Efeito do Teor de Aluminio do Solo sobre os Danos Causados por Spodoptera frugiper da (J.E. Smith, 1797) em Milho em Con-

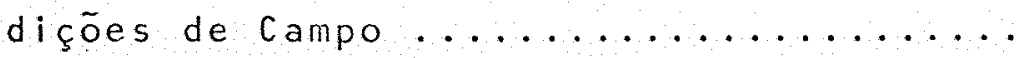

4.1.1. Niveis de infestação da cultura por s. frugiperda ............

4.1.2. Efeito de $S$. frugiperda sobreplan tas de milho em solo corrigido pa ra três niveis de alumínio ......

4.1.2.1. Altura da planta ......

4.1.2.2. Comprimento das espigas.

4.1.2.3. Peso de 100 grãos ......

4.1.2.4. Produção de grãos ..... 
4.1.3. Considerações gerais sobre o efei to da interação "danos causados pelo inseto - teor de alumínio do solo" sobre a planta ..........

4.2. Efeito do Teor de Alumínio do Solo sobre a Seleção do Milho como Hospedeiro por

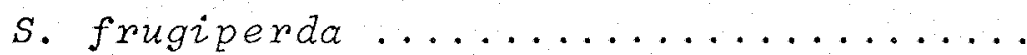

4.3. Efeito do Teor de Alumínio do Solo sobre a Biologia e Nutrição Quantitativa de $S$. frugiperda em Milho em Condições de Labo ratoorio .....................

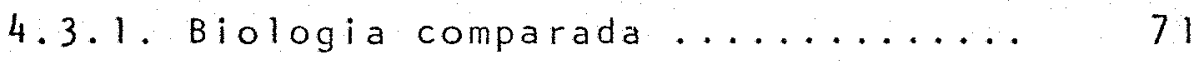

4.3.1.1. Fase de ovo......... 71

4.3 .1 .2 . Fase de lagarta ...... 71

4.3.1.3. Fase de pré-pupa ...... 7 ]

4.3.1.4. Fase de pupa........ 74

4.3 .1 .5 . Fase de adulto ...... 82

4.3 .1 .6 . Ciclo ovo-adulto....... 90

4.3.1.7. Tabela de vida de fertilidade ............. 90

4.3.1.8. Consideraçōes gerais sobre o efeito do teor de a lumínio no desenvolvimen to do inseto .........

4.3.2. Nutrição quantitativa ................... 93

4.3.2.1. Alimento ingerido ....99 95

4.3.2.2. Alimento assimilado.... 94

4.3.2.3. Alimento metabolizado(M) 98

4.3.2.4. Ganho de biomassa (B) .. 98

4.3.2.5. Indices nutricionais .... 98

4.3.2.5.1. Taxa de consumo rela tivo $(R C R) \ldots \ldots \ldots \ldots .98$

4.3.2.5.2. Taxa metabölica rela tiva (RMR) .........

4.3.2.5.3. Taxa de crescimento relativo (RGR)... 
Pägina

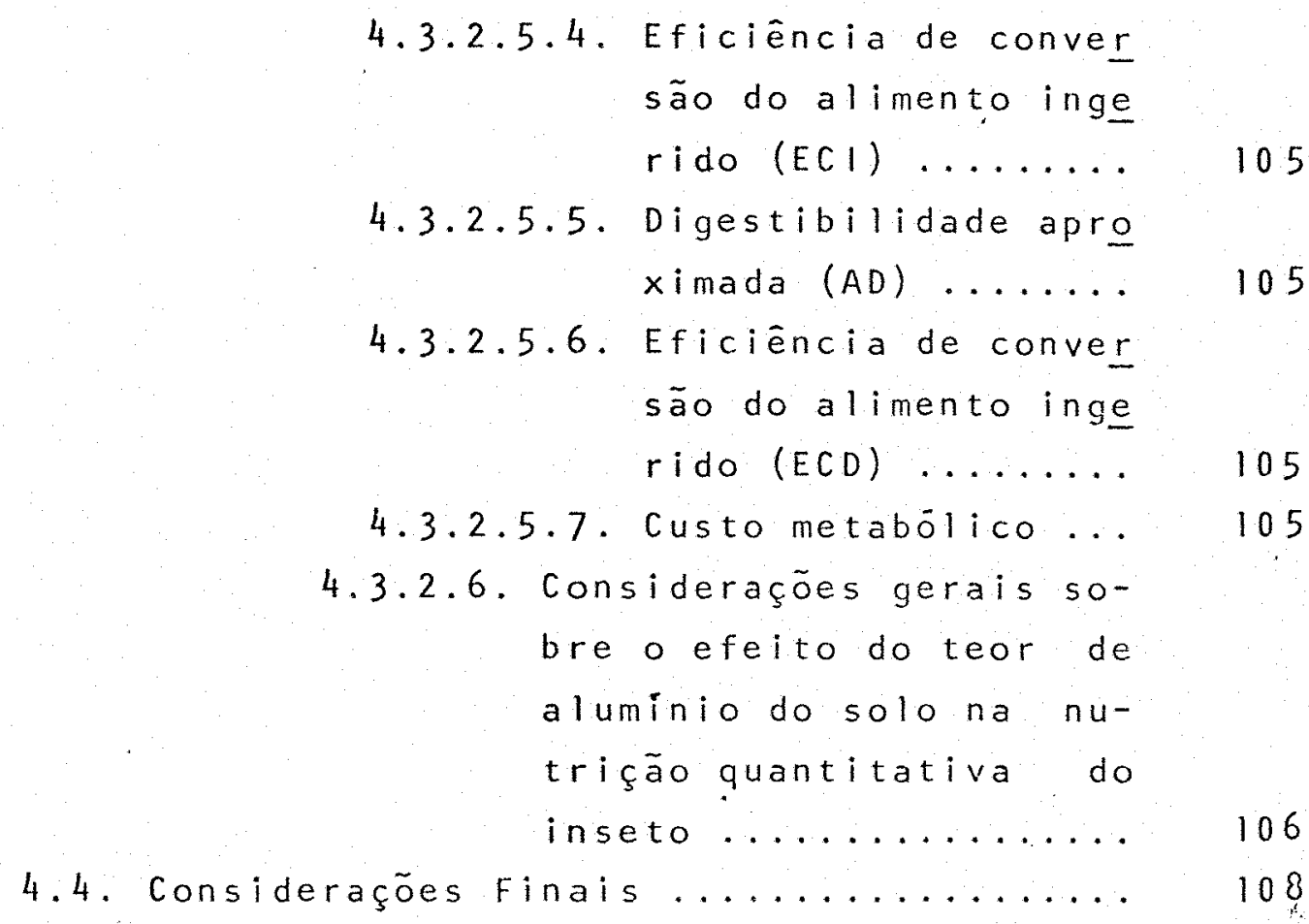

5. CONCLUSOES ..................... 111

REFERENCIAS BIBLIOGRÁFICAS .......... 113 
vii.

\section{LISTA DE FIGURAS}

FIGURA N?

Pägina

1

Curva de sobrevivencia e de longevidade média de adultos de $S$. frugiper da não alimentados, segundo o mode10 de distribuição de Weibull ......

2

Curva de sobrevivéncia de adultos de S. frugiperda alimentados com solução de sacarose $10 \%$ e ácido ascörbico $1 \% \quad \ldots \ldots \ldots \ldots \ldots \ldots \ldots \ldots$

Nümero e viabilidade de ovos por fêmeas, sobrevivência e porcentagem de fémeas que realizaram posturas de uma população de quinze fêmeas por

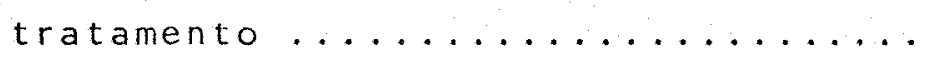




\section{LISTA DE TABELAS}

TABELA N?

Pàgina

1 Influência da nutrição da planta sobre

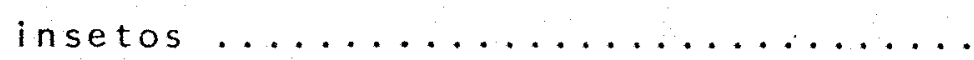

2. Composição da dieta artificial utiliza da para criação de $S$. frugiperda ....

3. Análise química do solo da área experimental antes da semeadura do se gundo ano (safra $84 / 85 \ldots \ldots \ldots$.

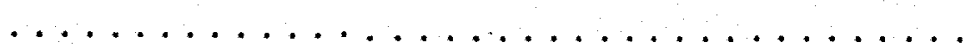

4 Anālise química do solo da ärea experimental na época de infestação artificial do segundo ano (Safra 84/

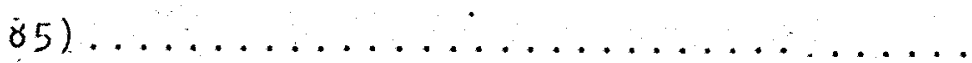

5 Adubação utilizada na semeadura do mi-

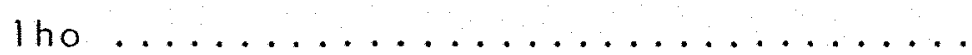

6 Porcentagem de plantas de milho infestadas por $S$. frugiperda em solo corrigido para três níveis de alumínio ....

7 Altura de plantas de milho $(\mathrm{cm})$ em solo corrigido para três niveis de alumi nio, s ob diversos niveis de infestação por $S$. frugiperda. Safra $83 / 84 \ldots \ldots$.

8 Comprimento médio $(\mathrm{mm})$ de espigas de milho produzidas em solo corrigido par ra três niveis de alumínio, sob diversos niveis de infestação por $S$. frugiperda. Safra $83 / 84 \ldots \ldots \ldots \ldots$. 
Comprimento médio $(\mathrm{mm})$ de espigas de mi tho produzidas em solo corrigido para três niveis de alumínio sob diversos ni veis de infestação por $S$. frugiperda. Safra $84 / 85 \ldots \ldots \ldots \ldots \ldots$

10 Peso de 100 grãos (g) de milho produzido em solo corrigido para três níveis de alumínio, sob diversos niveis de infestação por $S$. frugiperda. Safra $84 /$

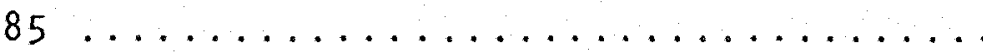

11. Peso de 100 grãos $(g)$ de milho produzido em solo corrigido para três niveis de alumínio, sob diversos niveis de infestação por $S$. frugiperda. Safra $84 /$ $85 \ldots \ldots \ldots \ldots \ldots \ldots \ldots \ldots \ldots \ldots \ldots \ldots \ldots \ldots \ldots \ldots$

Produção de grãos $(\mathrm{g})$ de milho em solo corrigido para trés niveis de aluminio, sob diferentes porcentagens de infesta ção por $S$. frugiperda. Safra. $83 / 84 \ldots$.

13 Produção de grãos $(g)$ de milho por plan tas infestadas e não infestadas por $S$. frugiperda em solo corrigido para três niveis de aluminio. Safra $83 / 84 \ldots \ldots$

14 Condições mëdias de temperatura, umidade relativa do ar e precipitação pluvial no local da pesquisa. Sete La-

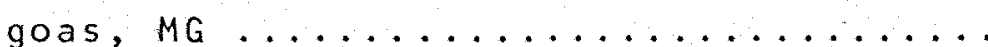

15 Produção de grãos ( $g$ ) de milho em solo corrigido para três niveis de alumínio, sob diferentes porcentagens de infestação por S. frugiperda. Safra $84 / 85 \ldots \ldots \ldots$. 
16 Produção (g) de grãos de milho por plan tas infestadas e não infestadas, por $S$. frugiperda em solo corrigido para três niveis de alumínio. Safra $84 / 85 \ldots .$.

17 Preferência de lagartas de $S$. frugiperda por folhas de mi tho produzidas em so 10 corrigido para três níveis de aluminio através da área foliar consumida 12 ?

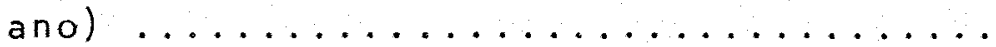

18 Duração e viabilidade da fase de ovo de S. frugiperda criada em milho cultivado em solo corrigido para trés niveis de aluminio, em condiçōes de laboratório ( 2 ?

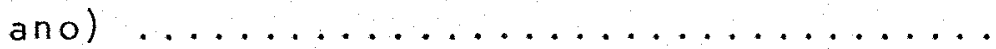

19 Duração e viabilidade da fase de lagarta de $S$. frugiperda criada em milho cul tivado em solo corrigido para três niveis de alumínio, em condições de labo-

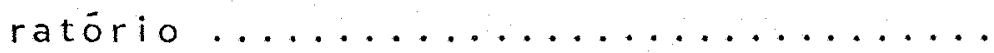

20 Razão de crescimento e duração média dos instares de $S$. frugiperda criada em milho cultivado em solo corrigido para très níveis de aluminio, em condições

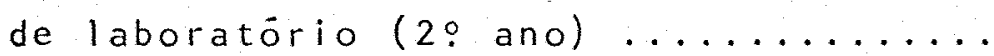

21 Duração e viabilidade da fase de pré-pu pa de $S$. frugiperda criada em milho cul tivado em solo corrigido para três níveis de aluminio, em condições de labo-

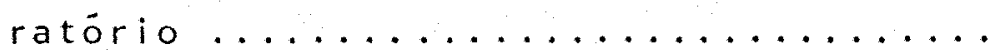


Duração da fase de pupa de $S$. frugiper da criada em milho cultivado em, solo corrigido para três niveis de alumí nio, em condiçōes de laboratörio....

23 Peso de pupas de $S$. frugiperda criada em milho cultivado em solo corrigido para três níveis de alumínio, em condi ções de laboratörio ..............

24 Razão sexual e viabilidade da fase de pupa de $S$. frugiperda criada em milho cultivado em solo corrigido para três niveis de alumínio, em condições de lą

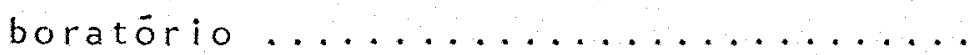

25 Longevidade de adultos não alimentados de $S$. frugiperda criada em milho cult vado em solo com três níveis de alumínio, em condiçōes de laboratório (1)

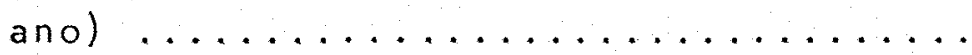

26 Longevidade média de adultos alimentados (com solução de sacarose $10 \%$ e àcido arcórbico $1 \%$ enão alimentados de S. frugiperda criada em milho cultivado em solo corrigido para três níveis de alumínio, em condições de laborató rio $(2$ a ano $) \ldots \ldots \ldots \ldots \ldots \ldots \ldots \ldots \ldots \ldots \ldots$

27 Porcentagem de adultos anormais de $S$. frugiperda em milho cultivado em solo corrigido para três níveis de aluminio, em condições de laboratório.... 
$x i i$.

TABELA N :

28 Duração dos períodos de pré-oviposição, oviposição e pós-oviposição de $S$. frugiperda criada em milho cultivado em solo corrigido para três niveis de aluminio, em condições de laboratörio ....

29. Nümero de dias de postura e número de ovos por fêmea de $S$. frugiperda criada em milho cultivado em solo corrigido para très níveis de aluminio, en condi ções de laboratório (2o ano) ..........

30 Duração do ciclo ovo-adulto de $S$. frugiperda criada em milho cultivado em so 10 corrigido para três niveis de aluminio, em condiçóes de laboratörio .......

31 Tabela de vida de fertilidade de $S$. fru giperda criada em milho cultivado em so lo corrigido para três niveis de aluminio, em condições de laboratörio

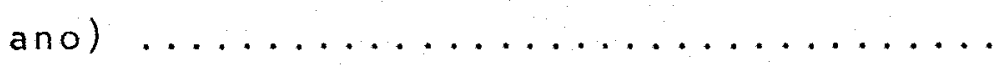

32 Relação peso seco/área foliar de milho e consumo em àrea foliar e peso seco por lagartas de $S$. frugiperda em solo corr gido para três níveis de alumínio (10

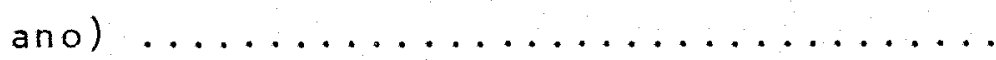

33 Relação peso secolärea foliar de milho e consumo em àrea foliar e peso seco por lagartas de $S$. frugiperda em solo corri gido para três niveis de alumínio (2?

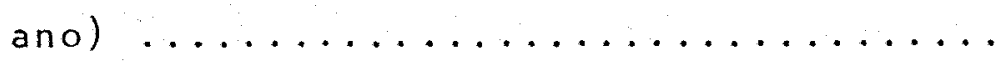


xiil.

TABELA N?

Página

34 Alimento assimilado por lagartas de $S$. frugiperda criadas em milho cultivado em solo corrigido para trés níveis de

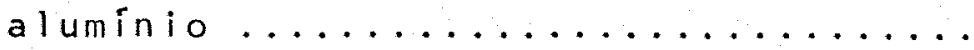

35 Alimento metabolizado por lagartas de S. frugiperda criadasem milho cultivado em solo corrigido para trēs níveis

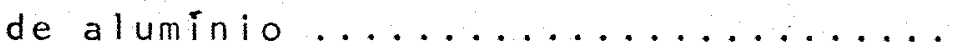

36 Ganho de biomassa (em mg de matéria se ca) por lagarta de $S$. frugiperda en $\mathrm{m} i$ tho cultivado em solo corrigido para

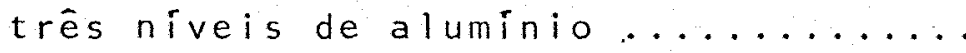

37 Tndices nutricionais (RCR, RMR, RGR, ECI, AD e ECD) para a fase larval de S. frugiperda, em milho cultivado em solo corrigido para três níveis de alu minio $(1$ i ano $) \ldots \ldots \ldots \ldots \ldots \ldots$

38 Indices nutricionais ( $R C R$, RMR, RGR, ECI, $A D$ e ECD) para a fase larval de S. frugiperda, em milho cultivado em solo corrigido para três niveis de alu mínio $(20$ ano $\ldots \ldots \ldots \ldots \ldots \ldots \ldots \ldots \ldots \ldots \ldots \ldots \ldots \ldots$

39 Custo metabólico (100 - ECD) para lagartas de $S$. frugiperda criadas em miTho cultivado em solo corrigido para

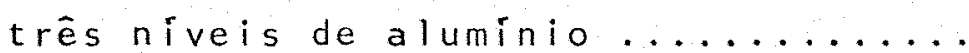


Biologia, Nutrigão Quant it at iva e Danos Causados por spodoptera frugiperda (J.E. SMITH, 1797) (LEPIDOPTERA: Noctuidae) em Milho Cultivado em Solo Corrigido para Três Niveis de Aluminio

Autora: LENITA JACOB OLIVEIRA

Orientador: Prof. Dr. JOSE ROBERTO POSTALI PARRA

\section{RESUMO}

o objetivo do trabalho foi estudar a influéncia do teor de alumínio do solo na biologia e nutrição quantitativa de spodoptera frugiperda (J.E. Smith, 1797) e no dano causado pela lagarta em plantas de milho.

0s experimentos de campo e laboratörio foram conduzidos, durante duas safras $(83 / 84$ e $84 / 85)$, no Centro Nacional de Pesquisa de Milho e Sorgo, da Empresa. Brasileira de Pesquisa Agropecuäria (EMBRAPA) em sete Lagoas, $M G$.

Para onsaio de campo foi escolhida uma faixa de solo uniforme, onde foram aplicadas diferentes doses de calcário, obtendo-se três níveis de alumínio. Também o teor de cálcio + magnésio foi variável, uma vez que se utilizou calcärio dolomitico. Dentro de cada nível de aluminio do solo estudaram-se seis niveis de infestação da cultura $(0 \%, 20 \%, 40 \%, 60 \%, 80 \%$ e $100 \%)$ por S. frugiperda, utilizando-se um delineamento experimental de blocos ao acaso com parcelas subdivididas. A infestação foi 
feita artificialmente, colocando-se trinta lagartas de se gundo e terceiro instares diretamente no cartucho da plan ta. Por ocasião da colhei ta avaliaram-se a altura da planta, comprimento das espigas, produção total de grãos e pe so de 100 grãos.

No ensaio de laboratório, o delineamento experimental foi inteiramente casualizado e as lagartas, provenientes de uma criação com dieta artificial, alimentadas com discos de folhas de milho procedentes de cada nivel de alumínio do ensaio de campo. Foram observados os seguintes parâmetros: duração e viabilidade de cada fase de desenvolvimento do inseto, nümero de duração dos ínstares, razão sexual, período de prē-oviposição, oviposição e pósoviposição, número de ovos colocados diariamente por fémea e peso de pupas. Foi elaborada uma tabela de vida de fertilidade e calculados indices nutricionais.

o teor de alumínio do solo afetou a biologia e nutrição quantitativa de $S$. frugiperda, sendo as folhas de milho produzidas em solo com baixo teor de aluminio as mais adequadas ao inseto. o quarto instar larval foi o mais sensível às variaçöes do teor de alumínio do solo, podendo ser utilizado como padrão para este tipo de estudo. os parámetros nutricionais foram mais adequados que os biológicos para avaliar a influencia do teor de alumínio e dentre os biológicos, a tabela de vida de fertilidade, foi o melhor parámetro para deteç̧ão destas diferenças. Deve-se realizar o controle de $S$. frugiperda em solos de cerrado, apenas quando o teor de alumínio não for alto. 
$x \vee i$

Biology, Quantitative Nutrition, and Damages Caused by Spodoptera frugiperda (J.E. SMITH, 1797) (LEPIDOPTERA: Noctuidae) in Corn Cultivated in Soil Corrected for Three Levels of Aluminium

Author: LENITA JACOB OLIVEIRA

Adviser: Prof. Dr. JOSE ROBERTO POSTALI PARRA

\section{SUMMARY}

The objective of this research was to study the influence of aluminium contents in the soil on the biology and quantitative nutrition of spodoptera frugiper da (J.E. Smith, 1797) as well as the level of damage caused by this larva on corn plants.

The field and laboratory experiments were conducted during two seasons $(83 / 84$ and $84 / 85)$ at the National Corn and Sorghum Research Center of EMBRAPA (Brazilian Agricultural Research Enterprise), in Sete Lagoas, $M G$.

A strip of uniform soil was selected for the trial, where different rates of lime were applied to obtain three levels of aluminium in the soil.

The calcium + magnesium contentswas variable, since dolomitic lime was utilized. Within each range of aluminium contents in the soil, six levels of crop infestation by $s$. frugiperda were studied: $0 \%, 20 \%, 40 \%, 60 \%, 30 \%$ and $100 \%$. The experimental design utilized was that of randomized blocks with split plots. Infestation was obtained artificially 
xvi i .

by placing thirty $2^{\text {nd }}$ and $3^{\text {rd }}$ instar larvae directly into the plant whorl. At harvest, plant height, length of corn ears, total kernel production and weight of 100 kernels were determined.

In the laboratory trial, the experimental design was entirely randomized and the larvae, originated from artificial diet rearing, were fed on corn leaf discs originated from each level of aluminum in the field trial. The following parameters were observed: duration and viability of each phase of development of the insect, number and duration of instar, pre-oviposition and postoviposition periods, number of éggs laid daily per female and weight of pupae. A fertility life table was prepared and nutritional indices were calculated.

The aluminium. contents of the soil affected the biology and quantitative nutrition of $S$. frugiperda; corn leaves produced in soil of low aluminium content were the most suitable to the insect. The fourth larval instar was the most sensitive to variations in aluminium contents of the soil; therefore, it may be used as a standard for this type of study. The nutricional parameters were more adequate than the biological ones for evaluating the influence of aluminium contents of the soil and, among the biological parameters, the fertility life table was the best for detecting these differences. The control of S. frugiperda in "cerrado" soils should be considered only when aluminium soil contents were not high. 


\section{INTRODUCÃO}

A lagarta-do-cartucho, spodoptera frugiperda (J.E. Smith, 1797), é originäria das zonas tropicais e ocorre em toda América (METCALF et alii, 1962; LABRADOR, 1967), tendo sido referida em treze Estados brasi leiros por LUCCHINI (1977).

E um inseto polifago que se alimenta de um grande nümero de plantas cultivadas, mas tem preferéncia por gramineas (METCALF et ali i, 1962; LABRADOR, 1967), sendo considerada uma das principais pragas do milho nas Américas (WISEMAN et alii, 1966).

No Brasil, o controle dessa praga tem sido feito basicamente com inseticidas químicos e embora existam produtos eficientes, o häbito da praga de se alo jar no interior do cartucho do milho, faz com que sejam necessärias formulações e métodos de aplicação especiais (NAKANO \& ZUCCHI, 1970; WAQUIL et alii, 1982; CRUZ et a)ii, 1983 e CRUZ \& SANTOS, 1984) que aumentam o custo do controle. Alguns pesquisadores brasileiros têm se preocupado com o problema, estudando a possibilidade de utiliza ção de variedades resistentes (CARVALHO, 1970 e CRUZ, 
1986) e o potencial de inimigos naturais (PATEL \& HABIB 1982; LUCCHINI, 1977; GARCIA \& HABIB, 1978; REIS et alii 1984 ; PEDRASI E PARRA, 1986; PEREYRA, 1986; VALICENTE, 1986a; VALICENTE, 1986b; VALICENTE et alii, 1986) visando ao seu controle.

Porém, dentro do conceito demanejo de pragas é importante estudar outros aspectos, além do controle propriamente dito, tais como fatores que influenciam o nível de dano elou biologia e comportamento do inseto e que devem ser considerados num programa global de controle da praga.

A literatura relata que os danos podem va riar em função do estádio da planta atacada e das condições ambientais no momento do ataque, sendo agravados quar do o ano é seco e o solo não é fértil o suficiente para permitir a recuperação da planta. Nestes casos, os prejui. zos podem ser totais se a população da praga for elevada, (LEIDERMAN \& SAUER, 1953; MENSCHOY, 1956; LABRADOR, 1967 ; CARVALHO, 1970 e CRUZ \& TURPIN, 1982).

o efeito dos danos na produção, entretanto, pode não ser função unicamente da capacidade de recuperação da planta, quando é atacada em determinados estádios ou condições ambientais, mas tambēm do efeito desses fatores sobre o próprio inseto.

Assim, muitos fatores biöticos e abióti cos podem afetar o desenvolvimento e comportamento dos insetos, e entre estes fatores, ofeito da qualidade do alimento sobre a fisiologia, desenvolvimento e niveis po- 
pulacionais de insetos é frequentemente negligenciado (SCRI BER \& SLANSKY JR., 1981 ).

Segundo PRATT et ali i (1972), há muitos exemplos na literatura nos quais compostos quimicos agricolas, como fertilizantes e inseticidas mudaram a proporção dos nutrientes nos tecidos da planta e consequentemen te, seu valor nutricional para as pragas, às vezes seleti vamente. Para esses autores, os métodos de controle baseados nesses fatores nutricionais podem ser promissores num pro grama de manejo de pragas.

No Brasil, hä poucos trabalhos nessa ärea e sendo a lagarta-do-cartucho uma das principais pragas do milho, tornam-se necessários estudos sobre o sistemá so lo-milho-lagarta, como mais um subsídio para o controle desse inseto. Assim, o objetivo do presente trabalho foi estudar a influência do teor de aluminio do solo na biolo gia e nutrição quantitativa de $S$. frugiperda e no dano causado pela lagarta em plantas de milho desdeque este elemento é muito importante em solo de cerrado, pois frequentemente ocorre em altos teores, prejudicando o desenvolvimento das plantas. 


\section{REVISÃO DE LITERATURA}

\subsection{BIOLOGIA DE spodoptera frugiperda (J,E, SMITH, 1797)}

A biologia de $S$. frugiperda tem sido muito estudada por diversos autores em diferentes países e condições.

A referência mais antiga desse inseto na literatura é de SMITH (1797) que relatou que a pupação ocorre no solo e a mariposa emerge cerca de 12 dias após a lagarta ter se dirigido ao solo, coincidindo com o periodo em que o milho ainda estä no campo, tornando a aração, como uma alternativa de controle, impraticável.

$$
\text { Estudos de campo e laboratório, feitos }
$$

por DEW (1913), mostraram que as mariposas ovipositam durante a noite, colocando cerca de 160 a 170 ovos sobre folhas de gramineas e algodoeiro entre outros vegetais. o período de incubação foi em mêdia de três dias; as lagartas apresentaram seis ínstares, durando a fase larval cerca de 14 dias. Fọ verificado que a pupação ocor 
re no solo, havendo a emergência dez dias depois. Segundo este autor, o ciclo total, à temperatura média de 250 C, foi de 30 dias.

SMITH (1921) relatou que sobre aveia, tri go e alfafa, o período de oviposição é de três dias e as posturas são feitas em massas na pägina inferior das foIhas. O período larval foi de 23 dias e o pupal de sete dias, em média.

LUGINBILL (1928) verificou que em milho a oviposição ocorre geralmente três a quatro noites após a emergência da fêmea, mesmo que não haja fertillização. o perío do de incubação foi mais influenciado pela temperatura do que pela umidade, sendo que a 26,790 as lagartas eclodiram em dois dias e a 20,69 C foram necessārios quatro dias para o desenvolvimento embrionário. o periodo larval foi de 12,1 a 29,7 dias e o pupal de 9 a 27 dias, dependendo das condições ambientais. A longevidade dos adultos, segundo esse autor, é influenciada pela alimentação e tempe ratura, e as mariposas viveram cerca de 13,3 dias, quando al imentadas, e 3,35 dias quando não al imentadas, róo havendo diferenças entre macho e fémea.

Segundo VICKERY (1929) a duração da fase larval de S. frugiperda em milho, foi de 12 dias a $26,7-27,49 \mathrm{C}$ e de 26 dias a $23 \% \mathrm{C}$.

ETCHEVERRY (1957) observou um encurtamento dos períodos de prē-oviposição, larval e pupal, quando elevou a temperatura de 15 para $229 \mathrm{C}$.

BOWLING (1967) constatou que a duração da fase larval foi de 31,2 dias, quando as lagartas foram 
criadas em dieta artificial à base de feijão a $25-280$, umidade relativa de $85-90 \%$ e fotofase de 14 horas. Nessas condições, as pupas pesavam em média $432 \mathrm{mg}$ e cada fêmea colocou, em mëdia, 696 ovos.

VELEZ \& SIFUENTES (1967) estudaram este inseto a $279 \mathrm{C}$ e $77 \%$ UR, sobre milho e constataram um período de incubação de quatro dias e fase larval de 21 a 22 dias, ocorren do apenas quatro instares. A longevidade do adulto foi de 15. dias e o período de pré-oviposição de cinco dias.

BURTON \& PERKINS (1972) observaram um periodo larval de 13,45 dias e cerca de 1901 ovos por fêmea, em dieta artificial à base de trigo e soja.

A biologia de S. frugiperda foi revisada por SPARKS (1979) e seu trabalho fornece dados sobre cada fase do ciclo biológico desta praga.

No Brasil, também foram realizados estudos sobre a biologia desse inseto.

Assim, BERTELS \& ROCHA (1950) verificaram que, em função da temperatura, o período de incubação durou até dez dias e o período larval foi de três a quatro semanas. observaram que a pupação ocorre no solo quandoes te ê arenoso ou, na própria planta de milho quando é argi loso, durando esta fase até duas semanas.

LEIDERMAN \& SAUER (1953) observaram em la boratório uma duração de até 25 dias para a fase larval e 19 dias para a pupal, quando o inseto foi criado em milho.

MENSCHOY (1956) verificou que, em milho, cada fêmea coloca até 1000 ovos e a população è maior nos anos se$\cos$ 
LUCCHINI (1977) estudou a biologia de $S$. frugiperda em milho dando ênfase ao efeito da luminosida de no desenvolvimento larval. A duração mẹdia do período de incubação foi de três dias. A lagarta apresentou sete instares e a duração dessa fase foi em média 14,67 dias. A duração do estägio de pupa foi significativamente diferente para o macho $(11,8$ dias) e fèmea $(10,17$ dias) o ci clo evolutivo também variou com o sexo, sendo de 31,2 ? dias para os machos e 30,17 dias para fêmeas. A longevida de dos machos foi de 21,1 dias e das fêmeas 12,4 dias. As posturas tinham em média 205,8 ovos com viabilidade de $91,22 \%$. Segundo esse autor, quando as lagartas foram cria das sem possibilidade de se protegerem da luz, o estáglo larval foi aumentado $(16,2$ dias $)$ e a mortalidade foi al ta $(64,3 \%)$.

KASTEN Jr. et alii(1978) realizaram estudos comparativos de biologia de $S$. frugiperda em duas dietas artificiais e substrato natural e observaram que embora a dieta à base de feijão possibilitasse a substituição do alimento natural, em criações de laboratōrios, em dieta natural o ciclo do inseto foi mais curto.

Estudos de FERRAZ (1982), em dieta artificial, mostraram que a temperatura influi marcadamente em todas as fases do ciclo biológico de $S$. frugiperda, sendo a temperatura de $25:$ C considerada a ma is favorál ao inseto. Este autor avaliou ainda o efeito da idade da planta de milho no desenvolvimento do inseto, observando que não houve influência na duração de nenhuma das fases imaturas. 
porém as maiores viabilidades ocorreram quando os insetos se alimentaram de folhas com 45 dias de idade.

PARRA \& CARVALHO (1984) desenvolveram estudos sobre $S$. frugiperda a $25: C, 70 \%$ UR e fotofase de 14 horas, em dieta artificial testando sete variedades de feijão e verificaram que a variedade Carioca se mostrou mais adequada, proporcionando um encurtamento do ciclo to tal $(31,53$ dias), uma maior viabilidade total $(63,65 \%)$ em relação às demaís, e pupas (fêmeas) $30 \%$ mais pesadas que a testemunha.

\subsection{Nutrição Quant ITATIVA}

A nutrição quantitativa consiste na ava liação das quantidades de alimento consumido, digerido, as similado, excretado, metabolizado e convertido em biomassa. A anälise desses parâmetros revela como o organismo responde a diferentes alimentos e quais componentes do alimento exercem maior efeito sobre o crescimento. Estudos de nutrição quantitativa de insetos têm auxiliado no conhecimento dos processos envolvidos na seleção hospedeira como preferência e antibiose, dando informações para elaboração de estratēgias de manejo de pragas, como por exem plo medidas de consumo e taxas de crescimento no desenvol vimento de modelos de simulação para determinação de níveis de dano económico de pragas (PARRA, 1980).

A adequação de um determinado alimento pa ra o inseto pode ser avaliada através de indices de consu 
mo e utilização, os quais foram padronizados por WALDBAUER (1968). Segundo esse autor, esses indices podem ser deter minados em função de algumas medidas básiças como peso se co ou fresco do alimento consumido, fezes produzidas e ga nho de peso pelo inseto durante o período experimental. SCR IBER \& SLANSKY JR. (1981) revisaram o assunto e propuseram algumas alterações nos indices estabelecidos por WALDBAUER (1968).

Segundo PARRA (1979), embora as exigências nutricionals dos insetos sejam bem conhecidas do pon to de vista qualitativo, o aspecto quantitativo tem sido pouco estudado devido às dificuldades técnicas na medição dos parâmetros necessários à avaliação do consumo e ut 111 zação do alimento.

KOGAN \& PARRA (1981) relataram que essés parâmetros podem ser avaliados por métodos diretos e ind retos, mas destacam que o método gravimétrico, no qual to dos os parâmetros são medidos diretamente usando uma balança, apresenta vantagens de ser mais simples, ter maior. acuidade e maior viabilidade para a maioria dos insetos, uma vez que os métodos indiretos exigem equipamentos sofisticados.

Segundo CROCOMO E PARRA (1985), a maior parte dos trabalhos encontrados na literatura mostra que os indices de consumo e utilização de alimento têm sido empregados como indicadores da adequabilidade de dietas a insetos, mas também têm sido utilizados no estudo das relações entre quantidade de alimento e conversão em substância corpörea; em trabal hos sobre comunidades ecologi - 
cas para avaliar a aptidão de complexos de espécies fitófagas em relação às plantas hospedeiras e em estudos visando investigar os mecanismos de resistencia de plantas a insetos e classificar os níveis dessa resistência.

\subsubsection{INFLUENCIA DE FATORES BIOECOLOGICOS SOBRE} A ALIMENTAÇÃO DOS INSETOS

A importancia da qualidade do alimento re lacionada a fatores ambientais e adaptações dos organismos que influenciam na utilização do alimento ingerido, desenvolvimento, fisiologia e niveis populacionais de artrópodos foi ressaltada por SCRIBER \& SLANSKY JR. (1981).

SLANSKY JR. (1982) descreveu a alimentação como um processo dinâmico e ativo, com numerosas inte. rações e consequências para o inseto, afetando sua sobrevivência, crescimento, reprodução e movimentação. Segundo esse autor, o paradigma da ecologia nutricional é baseado no princípio de que dentro de determinado ambiente há um estado ótimo de equilíbrio (tamanho do corpo, sincronização de eventos vitais, etc..) que resulta na máxima apti dão para o individuo. Segundo este autor, os estudos nessa ärea são baseados nos seguintes pontos: a) identificar como o estado de equilibrio ótimo difere entre espëcies e populações e dentro das populações através do tempo; b) como o individuo pode alterar, em resposta à mudança ambiental, seus processos fisiológicos e comporta mentais (taxa de consumo, metabolismo, etc.) para atingir e manter o estado de equilibrio ótimo; c) identificar as 
consequéncias ecolōgicas das alteraçöes destes processos;

ed) identificar como as respostas à mudança ambiental va riam entre populações e espécies. A partir destes parâmetros é possível compreender a evolução dos diferentes hä bitos alimentares dos insetos

Segundo SLANSKY JR. E SCRIBER (1985) os alimentos diferem quanto a composição química (nutrientes e aleloquímicos), facilidade de localização, tomada de alimento, abundância e persistência e essa variação exerce pressões seletivas que determinam adaptações envolvendo consumo e utilização do alimento. A determinação dessas pressões e adaptações resultantes constitui o âmago da ecologia nutricional. Esses autores observaram que, em condiçóes naturais, o inseto avalia o ambiente e "to ma" uma decisão expressa em respostas fisiolögicas, genēticas e comportamentais que podem ser de manutenção, compensação ou indução. A manutenção está associada com condições ambientais favoráveis. A resposta compensatória po de ocorrer, por exemplo, quando hã queda na concentração, de um nutriente no alimento, levando ao aumento no consumo, o que gera maior custo ecológico, uma vez que o maior tempo de alimentação pode aumentar a exposição a agentes de mortalidade. A indução pode ocorrer com mudança no fotoperíodo ou qualidade do al imento, levando à diapausa, mu dança de cor, alteração no tamanho ou na atividade de vôo.

A qualidade e quantidade do alimento ingerido pelo inseto podem influenciar não só a fase que o ingere como a fase subsequente. 0 alimento ingerido pela 
larva pode afetar sua taxa e tempo de desenvolvimento, pe so final do corpo, capacidade de dispersão e probabilidade de sobrevivencia, influenciando, às vezes, a performan ce do adulto subsequente (ex: a larva sofre redução no crescimento e produz adulto pequeno com baixa fertilida de). No caso do adulto, o alimento ingerido pode influenciar a habilidade de dispersão e acasalamento, tempo e ex tensão da reprodução e probabilidade de sobrevivência, afetando em muitos casos, também a larva de segunda geração (SLANSKY JR. \& SCRIBER, 1985).

\subsubsection{CONSUMO E UTILIZAÇÄO DE ALIMENTO POR} Spodoptera spp.

SOO HOO \& FRAENKEL (1966) estudarama taxa de ingestão, porcentagem de digestibilidade e eficiência de conversão do alimento ingerido e digerido durante - quinto instar de Prodenia eridania em 18 espécies e verificaram que algumas plantas não proporcionaram o crescimento larval devido a um ou mais dos seguintes fatores: baixa digestibilidade, baixa eficiencia de conver são e baixa taxa de consumo.

\section{BHAT \& BHATTACHARYA (1978) estudaram o} consumo e utilização de soja por S. Litura a diferentes temperaturas e observaram que o indice de consumo (C1) e a razão de crescimento (GR) cresceram com a temperatura. A eficiência de conversão do alimento ingerido (ECI) caiu com o aumento da temperatura e a eficiencia de conversão 
do alimento digerido (ECD) não foi correlacionada com a temperatura.

Estudos realizados por SCRIBER (1981) com S. eridania criada em diferentes hospedeiros, mostraram que a taxa de consumo, eficiência de alimentação e cresci mento larval não são características específicas, populacionais ou mesmo individuais, dependendo muito da variação de aleloquímicos e qualidade nutricional da planta. Posteriormente, SCRIBER (1982) estudou o efeito da alimen tação dos primeiros instares de $S$. exidania sobre o consu mo, assimilação e conversão de biomassa vegetal nos instares subsequentes, em três hospedeiros com diferentes graus de preferência e observou que não houve diferenças significativas na digestibilidade, mas a eficiência de as similação de biomassa e utilização de nitrogênio variou conforme o alimento dos primeiros instares.

PARRA \& CARVALHO (1984) estudaram o crescimento e nutrição de $S$. frugiperda em dietas artificiais à base de feijão, comparando sete variedades desta legum nosa e concluíram que houve diferença nos indices nutricionais em função da variedade de feijão utilizada.

CROCOMO \& PARRA (1985) estudaram o consumo e utilização de milho, trigo e sorgo por $S$. frugiperda. Foi verificado que as lagartas apresentaram capacidade de compensar as dificuldades de utilização encontradas nos diferentes hospedeiros e manter a performance de desenvol vimento. As lagartas mantidas em trigo apresentaram as me nores taxas de consumo e custo metabólico e as maiores efi ciências de conversão do alimento ingerido e do digerido. 
o ganho de biomassa foi semelhante nos três hospedeiros, sendo o custo metabólico maior quando se alimentaram de milho. Assim, o trigo foi o alimento que apresentou melho res caracteristicas nutricionais e o milho foi o hospedei ro que mais afetou a fisiologia e comportamento alimentar das lagartas.

\subsection{Efeito do Estado Nutricional da Planta sobre os INSETOS}

As substâncias químicas originārias das plantas, incluindo aquelas liberadas no ar e no solo, afe tam o inseto antes ou no momento em que entram em contato com a planta. Outras substáncias contidas no tecido vegetal agem somente após a destruição dos tecídos (KOGAN, 1976). Muitas dessas substâncias não têm função nutritiva e foram denominadas aleloquimicos por WHITTAKER \& FEENEY (1971)

As substâncias secundārias, sem valor nutritivo, são comumente apontadas como responsáveis pela seleção hospedeira, porém, SCHOONHOVEN (1972) chamou a atenção para o fato de que as espécies de plantas diferem também quantitativamente no seu conteüdo de nutrien tes, o que pode afetar o comportamento elou biologia do inseto que dela se alimenta, e EDWARDS \& WRATTEN (1980) re lataram que pequenas mudanças no material que a plantafor nece ao herbivoro podem afetar fundamentalmente sua performance. 
Embora a maior parte dos trabalhos ressal tem que a qualidade nutricional de uma planta seja ineren te à prōpria espécie, esse valor pode ser afetado por fatores não genéticos.

PRATT et alii (1972) citaram muitos exemplos na literatura, nos quais produtos quimicos agricolas (fertilizantes, inseticidas, herbicidas, etc.) mudaram a proporção dos nutrientes nos tecidos da planta e, conse quentemente, seu valor nutricional para as pragas, às vezes seletivamente. A mudança na composição nutricional da planta pode resultar em indisponibilidade, falta ou inade quação da quantidade ou proporção de nutrientes para o in seto.

Os nutrientes podem afetar a manifestação da resistência de plantas a insetos quer agindo sobre o inseto, quer sobre a própria planta (LEUCK, 1972).

De acordo com WISEMAN et alii (1973b) e LEUCK \& HAMMONS (1974a) anutrição mineral da planta pode ter importante influência na expressão da resistência da planta ao ataque de insetos.

Segundo FOX \& MAGAULEY (1977) tanto a qua lidade do alimento quanto o nitrogénio são elementos críticos na ecologia de muitos insetos, parecendo que as lar vas ajustam suas taxas de alimentação com o propósito de proporcionar uma máxima acumulação de nitrogênio. WHITE (1978) relatou que se o nitrogènio for indisponivel ou es tiver em baixo nivel, larvas novas de muitos insetos podem sofrer alta mortalidade.

MCNEILL \& SOUTHWOOD (1978) relatam que 
muitos insetos alimentam-se sobre diferentes partes da planta nas diferentes estações do ano e isto parece estar relacionado com os locais de máxima disponjbilidade de ni trogênio.

Segundo LARA (1979), nem todas as plantas possuem os mesmos elementos em sua composição e quando apresentam, estes não se encontram nas mesmas proporções, fazendo com que os insetos prefiram as que lhes fornecem um alimento nutricionalmente favorável, evitando aqueles que possuem carência, deficiência ou balanceamento nutricional desfavorável a seu desenvolvimento.

De acordo com ARCHER et alii (1982), peque nas diferenças nutricionais na planta são capazes de cásar variações na densidade populacional de insetos, associação essa que ajuda a compreensão da relação plantalinse to visando ao planejamento de programas de manejo de pragas.

MATTSON JR. (1983) observou que o conteü do de nitrogênio de uma planta é apenas uma de suas carac terísticas que são vitalmente importantes para os insetos, uma vez que desempenha função essencial em todos os processos metabólicos dos mesmos.

2.3.1. EFEITO DA FERTILIDADE DO SOLO E FERTILIZANTES SOBRE INSETOS

o efeito da adubação no solo sobre o teor de nutrientes da planta e consequentemente sobre os insetos que dela se alimentam tem sido estudado por värios pesquisadores. 
Uma revisão feita por SHARMA (1970) mostrou que várias ordens de Insetos podem ser afetadas pela ação de adubação com potássio, nitrogênio e fósforo, concluindo que o efeito desses nutrientes é variāvel. Esse autor salientou que na pesquisa relativa à utilização de fertilizantes para um melhor crescimento da planta, devese considerar também a influência desse crescimento no de senvolvimento de insetos fitófagos. Assim, ainda que certos resultados mostrem que a aplicação de adubos reduz a população de pragas, para a maioria dos insetos sugadores e alguns mastigadores, a fertilização do solo tem efeito benëfico, aumentando sua população.

Segundo MAXWELL (1972), não se pode chegar a conclusões generalizadas sobre o efeito de fertilizantes sobre insetos, porque a importancia de cada nutriente varia com a espécie, planta hospedeira e tipo de so1o. Esse autor ressalta que certas espécies ou variedades de plantas têm maior habilidade que outras para extrair produtos quimicos do solo e essa maior absorção e uso dos elementos contribuem para a resistência a insetos. TANDON (1973) relatou que trabalhos realizados na India mostraram que o efeito dos fertilizantes sobre os insetos varia com o nutriente e a espécie.

2.3.1.1. Efeito da nutrição da planta sobre insetos sugadores

A literatura mostra diversos trabalhos so 
bre o efeito da nutrição da planta sobre insetos sugadores, principalmente em relação ao nitrogênio.

EVANS (1938) observou que a reprobução de Brevicoryne brassicae está positivamente correlacionada com o conteüdo de nitrogênio da planta, em particular com o tear de proteínas. A produção de alados está negativamente correlacionada com os mesmos fatores.

BAKER \& TAUBER (1954) observaram que a fe cundidade de Macrosiphum pisi em plantas de ervilha diminulu à medida em que foram reduzidos os niveis de nitrogênio aplicados à planta.

SHARHA (1970) revisou vários trabalthos que tratam desse assunto e verificou que, em relação aos af deos, as informações são abundantes e contraditórias, pois embora a maioria dos trabalhos evidencie que altos teores de nitrogênio aumentam a reprodução de pulgōes, há casos em que ocorre o oposto.

HARREWIJN (1970) observou que a fecundida de e reproduçäo de Myzus persicae em batata mantida em solução nutritiva, estão positivamente correlacionadas con o teor de nitrogênio na solução.

MAXWELL (1972) citou um trabalho no qual foi estudado o efeito de quantidades médias, excessivas e deficientes de cálcio, nitrogênio, potássio, fósforo e en xofre sobre o afideo, Therioaphis maculata, em variedades resistentes e suscetiveis de alfafa. Verificou-se que nenhum tratamento tornou as variedades suscetiveis mais resistentes, mas a resistência foi significativamente diminuída, porém não eli ininada, quando as variedades resisten 
tes foram tratadas com níveis deficientes de cálcio ou po tássio e excesso de magnēsio ou nitrogênio. Níveis deficientes de fösforos aumentaram a resistência, que näo foi afetada pelo enxofre.

Trabalhos revistos por PRATT et alil (1972) mostraram que o nitrogênio solüvel nas foltias se aumenta do, resulta em maior fecundidade de M. persicae. Variações na quantidade de $N-P-K$ em fumo, podem alterar o conteúdo destes elementos nas folhas e a taxa de aumento da população de $M$. persicae.

Segundo TINGEY \& SINGH (1980), muitos afideos dependem da nutrição de seu hospedeiro. Trabalhos re vistos por esses autores mostraram que deficiência de nitrogènio no solo acentuou a performance de Schizaphis gre minum e de Aphis fabae em värias espécies de leguminosas. A deficiência de fósforo em milho prejudicou s. graminum. e niveis baixos de potássio aumentaram a fecundidade de B. brassicae.

Em trabalho relacionando a densidade de S. graminum em sorgo com värios niveis de nitrogênio, ARCHER et alii (1982) verificaram que este elemento não alterou a tolerância natural dessa planta ao inseto.

$$
\text { JANSSON \& SMILOWITZ (1986) estudaram a }
$$

influência do nitrogénio sobre $M$. persicae em batata e observaram que a taxa de crescimento da população do afídeo aumentou com o nivel de nitrogênio aplicado; entretanto, o maior nivel de nitrogênio $(224 \mathrm{~kg} \mathrm{~N} / \mathrm{ha})$ reduziu essa taxa. 
Embora o volume maior de trabalhos seja com afídeos, outros insetos sugadores têm sido estudados.

Uma revisão realizada por SHARMA (1970)

mostrou que o teor de nitrogênio está positivamente relacionado.com a performance de Heliothrips haemorrhoidalis em espinafre e Empoasca devastans em algodão, mas seu efeito é prejudicial para Blissus leucopterus em sorgo; entretanto os ataques desse percevejo eram aumentados com ouso. de superfosfato.

PFEIFFER \& BURTS (1983) estudaram o efeito do nitrogênio sobre Psyzza pyricola em pera e verificaram que a taxa de desenvolvimento dos psilídeos aumentou nas ārvores tratadas com esse nutriente.

Ensaios realizados por LUBUS et alii (1984), mostraram que adubação com enxofre e molibdénio em amendoim năo teve influência sobre tripes (Caliothrips brasiziensis e Enneothrips flavens).

\subsubsection{Efeito da nutrição da planta sobre insetos mastigadores}

Entre os mastigadores, os lepidōpteros têm sido os mais estudados.

TAYLOR et alii (1952) realizaram ensaios de campo e em casa de vegetação com ostrinia nubizalis em milho e, em ambos os casos, o crescimento e sobrevivencia do inseto foram melhores nas plantas vigorosas do que aque las com deficiência de nitrogênio, potássio ou potássio e fösforo. 
ISHII (1967) e ISRAEL (1967) verificaram que o nivel de dano causado por brocas-do-colmo enarroz elevou-se com o aumento das doses de nitrogênio na cultura.

Trabalhos revistos por SHARMA (1970) mostraram que o nitrogénio aumentou a mortalidade da lagarta do microlepidóptero Evetria briolina e vários microlepidó pteros, entre os quais Lymantria monacha e L. dispar.

SELL \& BODZNICK (1971) observaram que $\mathrm{ZnSO}_{4}$ $.7 \mathrm{H}_{2}$ ) a $0,2 \%$ ou mais concentrado adicionado a meio artif cial, causou severos prejuizos no desenvolvimento, levan do lagartas de Heliothis virescens à morte.

SHAW E LITTLE (1972) observaram o efeito da adubação de abeto balsămico com nitrogênio, fósforo potássio sobre Choristoneura. fumiferana e concluiram que lagartas criadas nas árvores adubadas tinham pupas e mariposas (fêmeas) mais pesadas e uma maior sobrevivência do que aquelas criadas em ärvores não adubadas. Notaram, a in da, que a folhagem das árvores adubadas, tinha maior teor de água, cinzas, eçúcares totais, nitrogênio e calor de combustão e menos carboidratos por taxa de nitrogénio.

WISEMAN et ali (1973b) observaram que $\#$. zea mostrou preferencia por folhas de milho tratadas com NP em relação a folhas com $P, K, P K$ ou não adubadas.

MARTINS et alii (1978), estudando a influéncia de vários níveis de nitrogênio em arroz irrigado, verificaram que o dano causado por Diatraea saccharalis está diretamente correlacionado com o aumento dos niveis de nitrogênio. 
Segundo AUERBACH \& STRONG (1983) alguns lepidópteros aumentam seu consumo total e sua taxa alimen tar sobre plantas que apresentam baixa concentração em ni trogênio, para manter a taxa de crescimento, visando obter teores de nitrogênio equivalentes àqueles em plantas com altas concentrações de nitrogênio. Consequentemente, os insetos passam mais tempo se alimentando e ficam mais expostos aos inimigos naturais.

BREWER et alii (1985) estudaram a influên cia dos niveis de nitrogénio na folhagem de duas espécies de abetos sobre Choristoneura occidentalis e verificaram. que a mortalidade larval e a tempo de desenvolvimento foram maiores no nivel mais baixo de nitrogênio $(1,29 \%)$.

Na literatura encontram-se também trabaIhos com outras ordens de insetos. A revisão feita por SHARMA (1970) mostra exemplos nos quais o nitrogênio afeta negativamente espécies de curculionidae e scolytidae, mas favorece o gafanhoto, Melanoplus mexicanus. Tratamento con potássio estimulou o ataque de gorgulhos em pinheiro branco.

JANSSON E SMILOWITZ (1985) observaram que a taxa de desenvolvimento da populaçăo de Lepitinotarsa de cemlineata (Chrysomelidae) no campo está negativamente cor relacionada com a concentração de nitrogênio nas folhas de batata e sugeriram que a adubação nitrogenada pode ser importante no manejo de pragas dessa cultura.

2.3.1.3. Efeito da nutrição da planta sobre spodoptera spp.

LEUCK (1972) estudou os efeitos da adubação de pennisetum typhoides sobre lagartas de $S$. frugi- 
perda e observou que os tratamentos com N, P, NK e PK apresentaram efeito antibiótico sobre as lagartas, reduzinco seus pesos em comparação com a testemunha não adubada. A combinação $N K$ e apenas $N$ causaram $10.0 \%$ de mortá lidade larval. Entretanto, os tratamentos NP e NPK proporcionaram melhor desenvolvimento e lagartas com maior ganho de peso. Foi observado tambem que follas de plantas adubadas com NP $O$ NPK foram altamente preferidas para alimentação em testes de livre escolha.

WISEMAN et alii (1973a) trabalhando com milho do Grupo Antiqua (de resistência moderada) tratado com combinações de NPK, observaram que folhas tratadas com NP foram preferidas por $S$. frugiperda quando comparadas com aquelas tratadas com $P, K, P K$ ou não adubadas. 0 nitrogênio reduziu a duração do periodo pupal e aumentou o peso das lagartas e sobrevivencia do inseto.

Folhas de milho tratadas com zinco produziram efeitos antibióticos em lagartas confinadas (WISEMAN et alii, 1973b).

$$
\text { A resistência de amendoim e } S \text {. }
$$

frugiperda tambèm fol afetada com o uso de fertilizantes inorgànicos e essa influência variou conforme o substrato utilizado. No solo, a aplicação de PK conferiu reslstência à planta, mas a aplicação de N, NP e NK aumentou a suscetibilidade do vegetal, que quando não adubado ou na presença de $N, K$, e NPK, apresentou um grau inter mediário de resistência. Em areia, somente a adubação com NPK e NK conferiu un nivel intermediärio de resistencia; as demais plantas, inclusive as não adubadas se mostraram re 
sistentes. Já em vermiculita, plantas adubadas com $N, N K$

e PK mostraram resistência intermediária e os outros tra tamentos foram resistentes (LEUCK \& HAMMONS, 1974a).

o efeito de sais inorgânicos diluídos e

aplicados em folhas de grama bermuda, milho e sorgo, sobre o comportamento de lagartas de primeiro instar de $S$. frugiperda foi estudado por LEUCK et alii (1974), que cons tataram que todos os compostos utilizados (à base de $S$, $\mathrm{Cu}, \mathrm{Mo}, \mathrm{Fe}, \mathrm{Mg}, \mathrm{B}, \mathrm{Na}, \mathrm{Zn}, \mathrm{Al}, \mathrm{Ca}, \mathrm{K}, \mathrm{Mn}, \mathrm{Co}, \mathrm{Cr}$ e l) tor naram a grama bermuda não preferida para alimentação. Para milho, o resultado foi semelhante com exceção do molib dato de sódio, que conferiu resistência intermedária. No caso do sorgo, folhas tratadas com molibdato de sódio, sulfato de aluminio e óxido de magnésio foram preferidas para alimentação e aquelas tratadas com quelato de ferro, borato de sódio ou sulfato de câlcio tiveram um grau de preferência intermediário; as demais (tratadas com sul fato cúprico, sulfato de zinco, permanganato de potássio, sulfato de amônia e cloreto de sódiol foram não preferidas.

LEUCK \& HAMMONS (1974b) testaram, em casa de vegetação, quinze compostos inorgânicos pulverizados so bre folhas de amendoim e verificaram que esses compostos afetaram a resistência dessa cultura a $S$. frugiperda.

o efeito da adubação de beterraba com diferentes niveis de nitrogênio sobre spodoptera exigua foi estudado por AL-ZUBAIDI \& CAPINERA (1983). Houve uma correlação inversa entre o conteüdo de nitrogênio na 
folha e a porcentagem de canibalismo, sendo a fecundida de aumentada pela atividade canibal.

CARVALHO et alii (1984) estudaram o efeito do potássio no solo e em solução nutritiva mais areia lavada, sobre S. frugiperda e observaram que resultados mais significativos foram obtidos no ensaio com solo. A falta de potássio induziu uma maior oviposição e as lagar tas ocorreram em maior nümero e foram maiores.

LYNCH (1984) testou três niveis de nitrogênio $(448,224$ e $0 \mathrm{~kg} / \mathrm{ha})$ em grama berm da visando avaliar seu efeito sobre $S$. frugiperda. observou que a sobrevivencia larval, peso, taxa de desenvolvimento e peso de pupas foram maiores nas plantas que receberam nitrogênio do que naquelas não adubadas. Notou tambēm que a população pode aumentar de 45 a 225 vezes nas pastagens adubadas com maior teor de nitrogênio em relação às não. adubadas.

CLAVIJo (1984) estudou o efeito da aduba ção nitrogenada e de värios níveis de infestação $10 \%$ a $80 \%$ ) por S. frugiperda sobre a produção sem nenhum efeito da porcentagem de infestação, pois as parcelas com diferen tes niveis de plantas infestadas não tiveram produções es tatisticamente diferentes.

Tendo em vista a escassez de trabalhos re lacionando nutrição de plantas a insetos, especialmente no Brasil, um resumo dos mesmos è apresentado na Tabela 1 . 


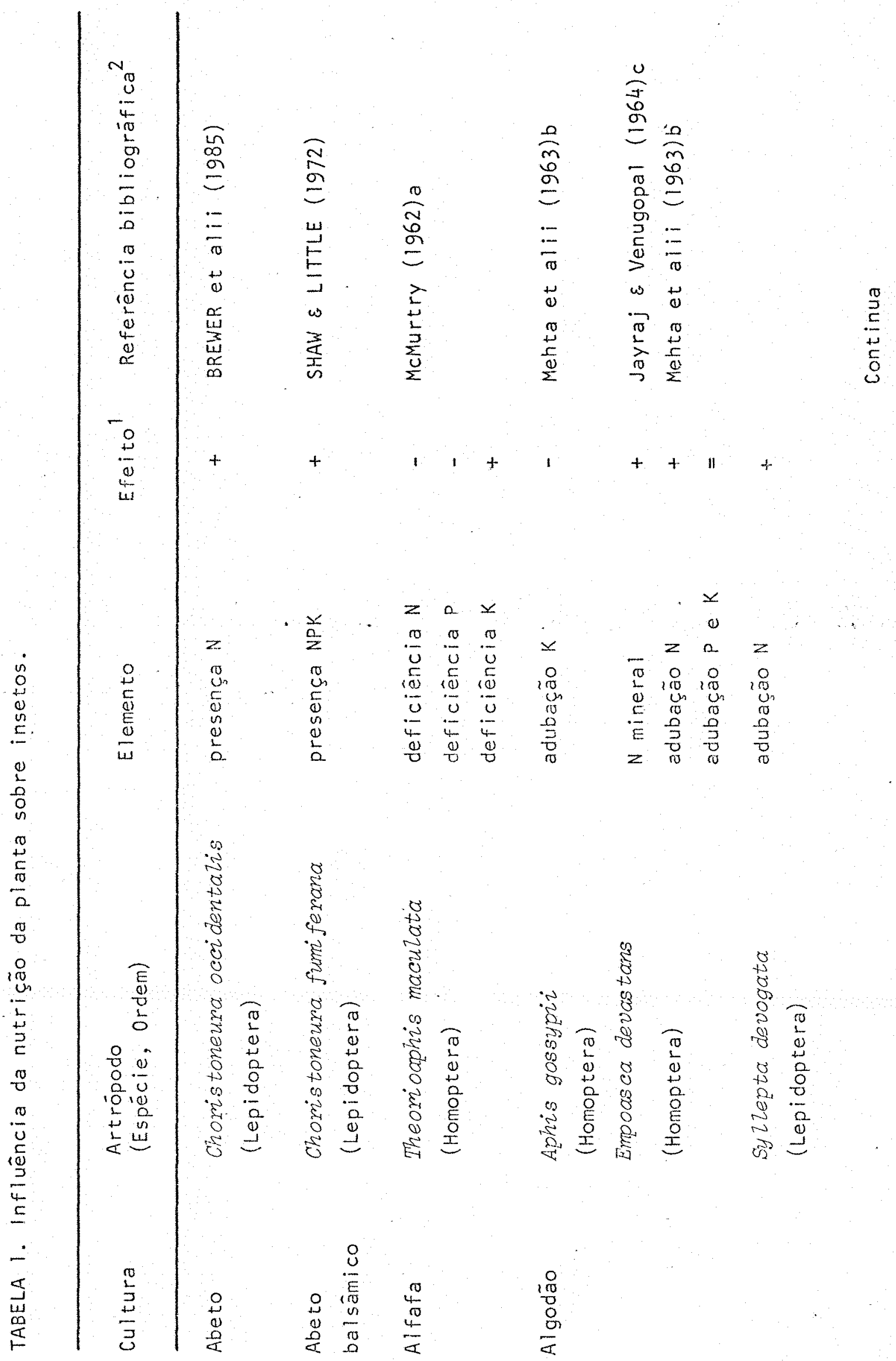




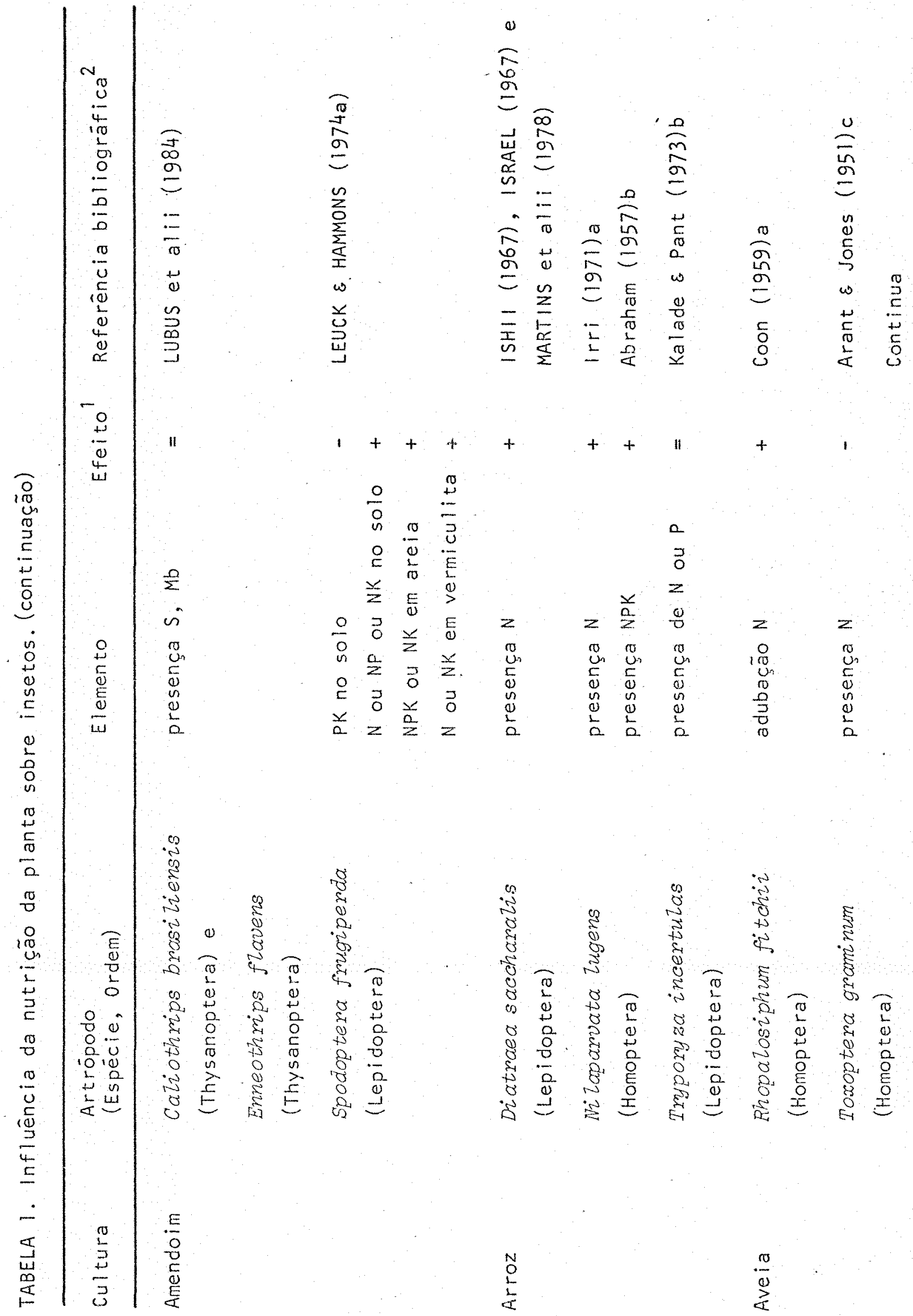




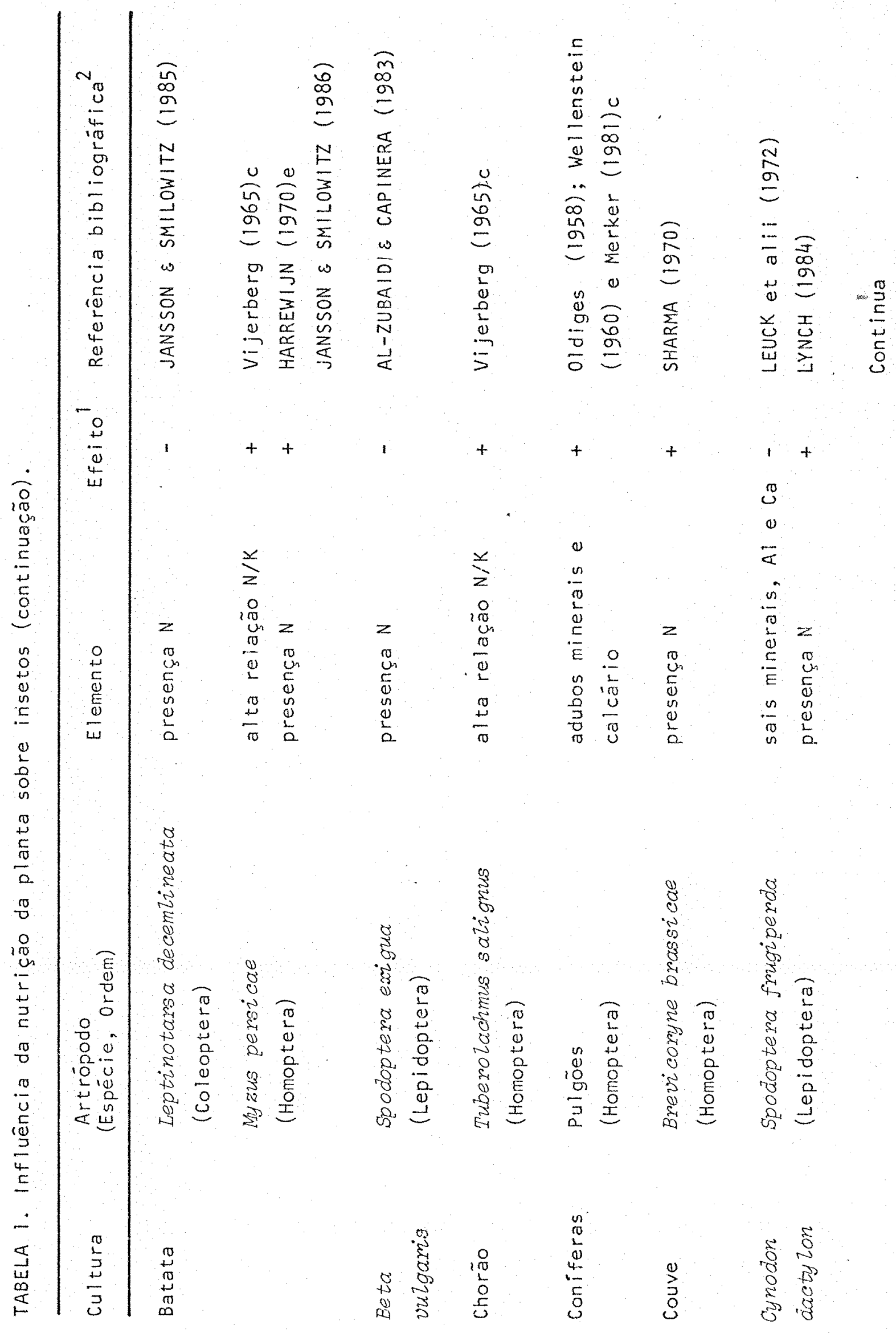




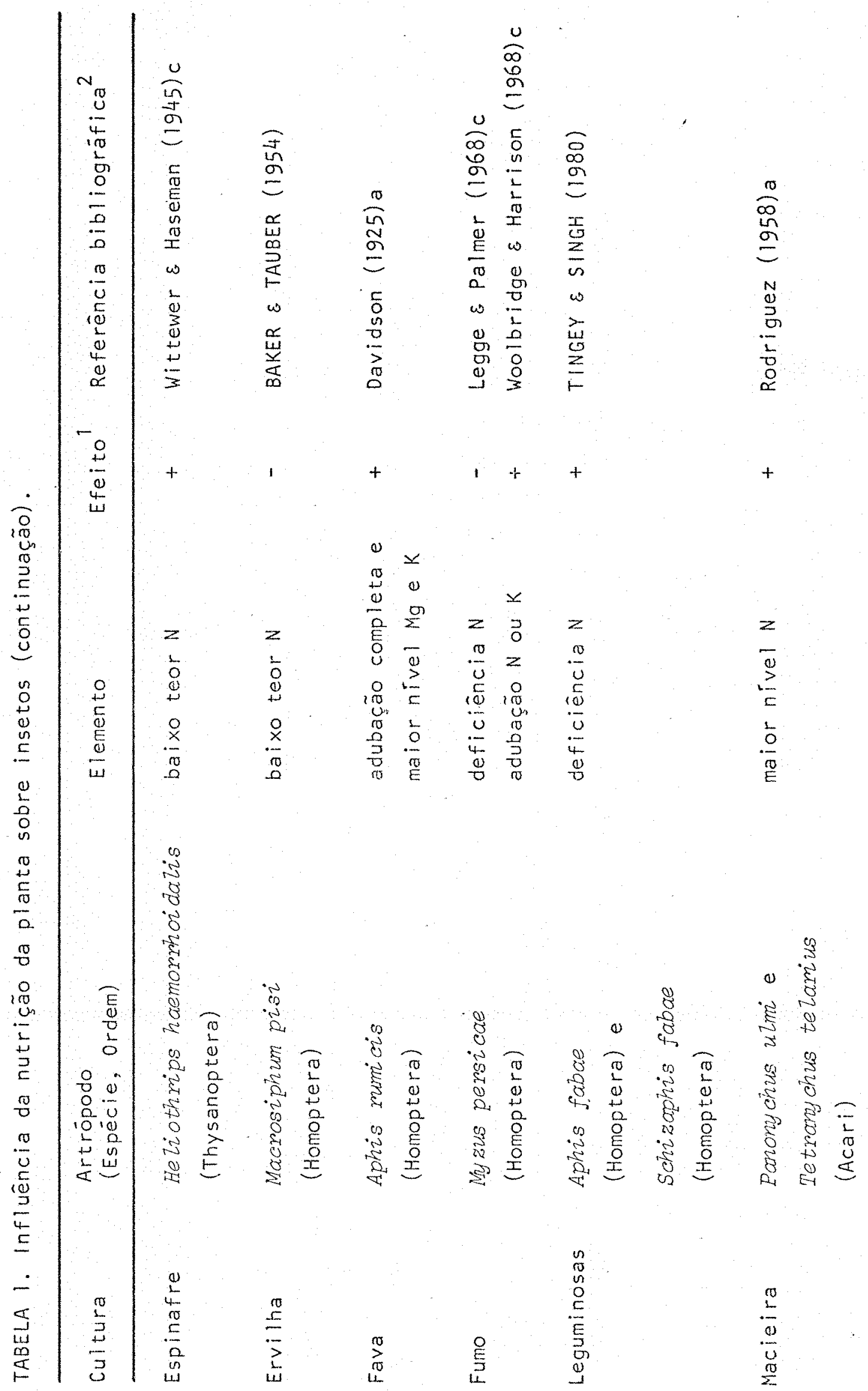




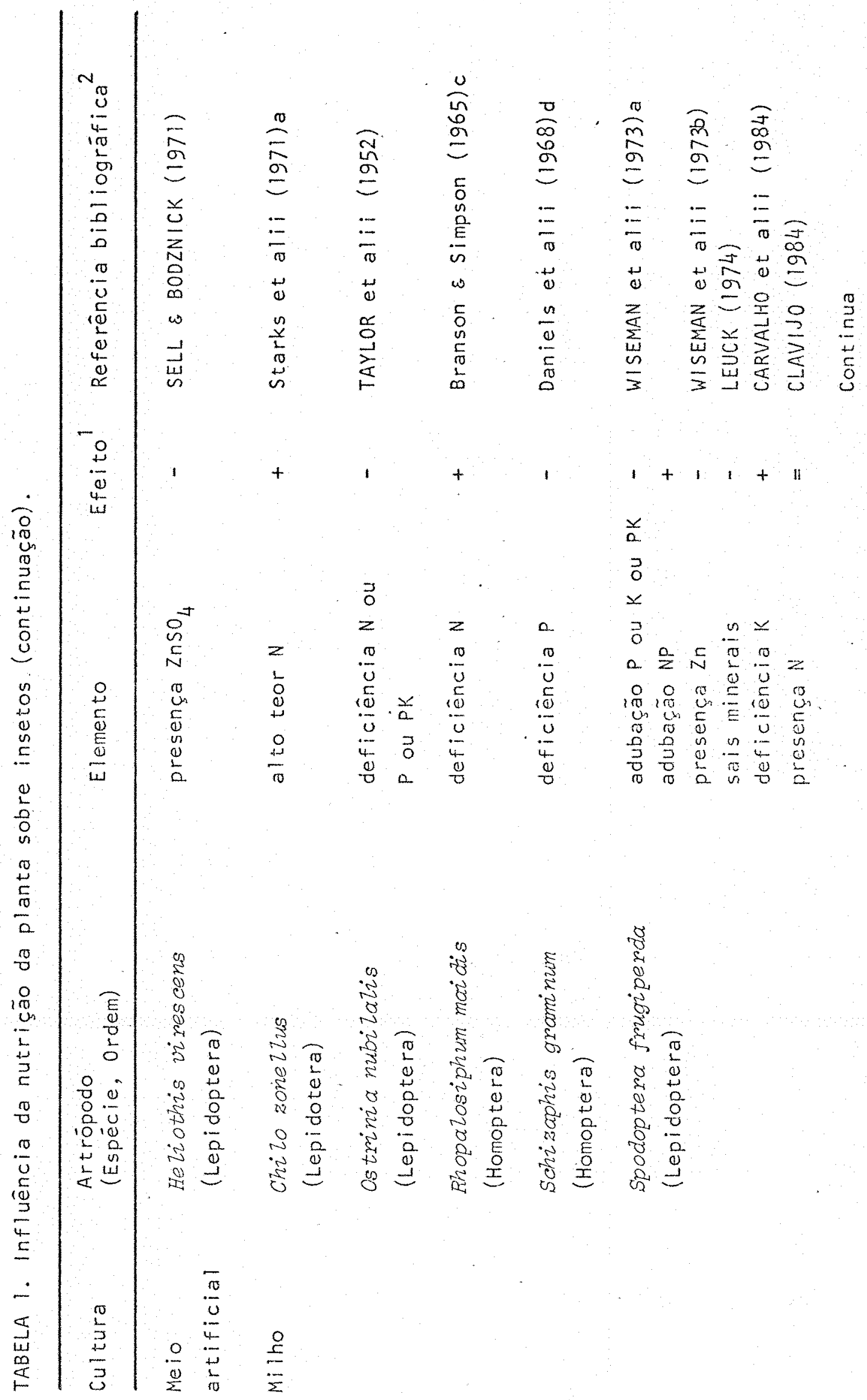




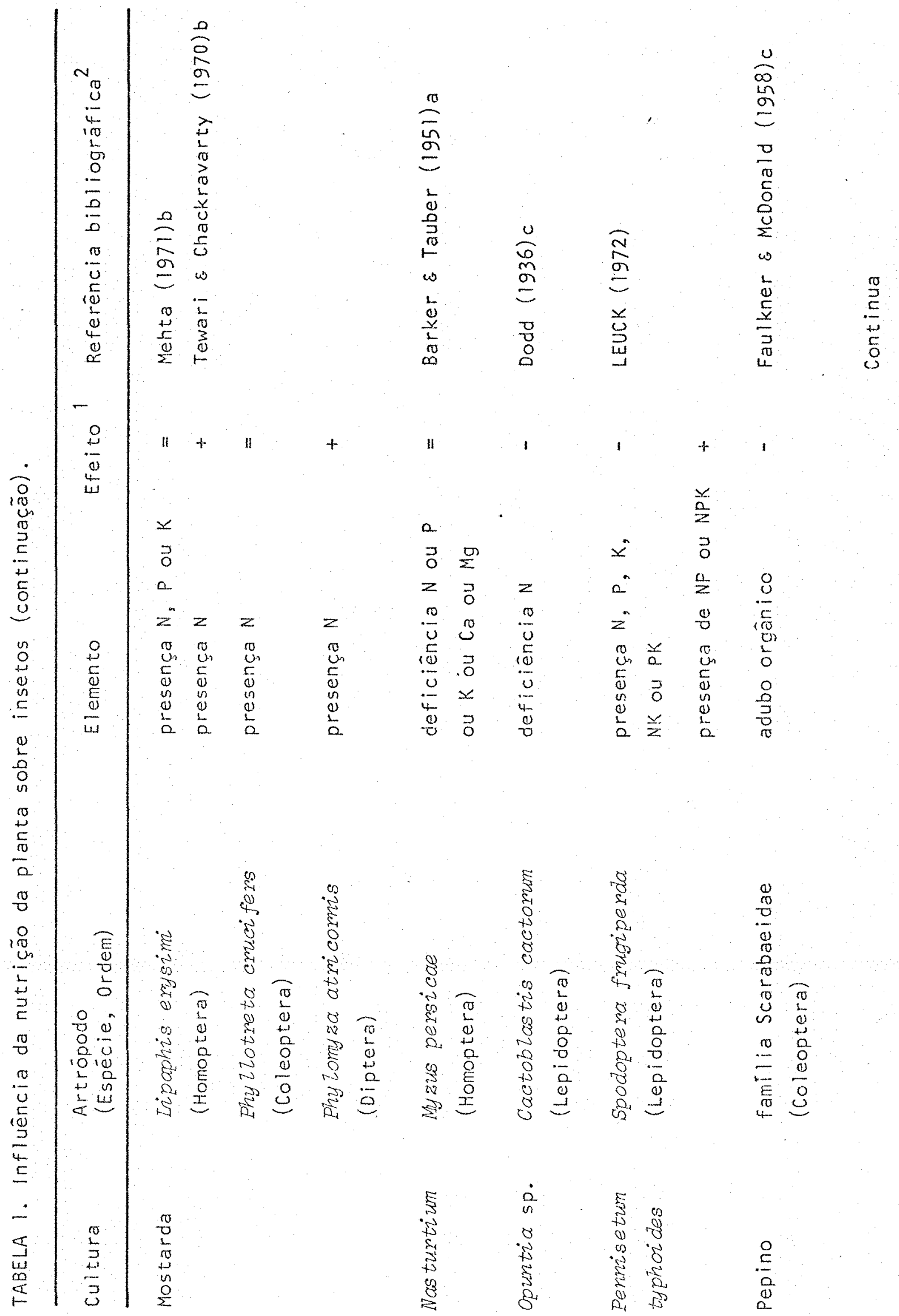




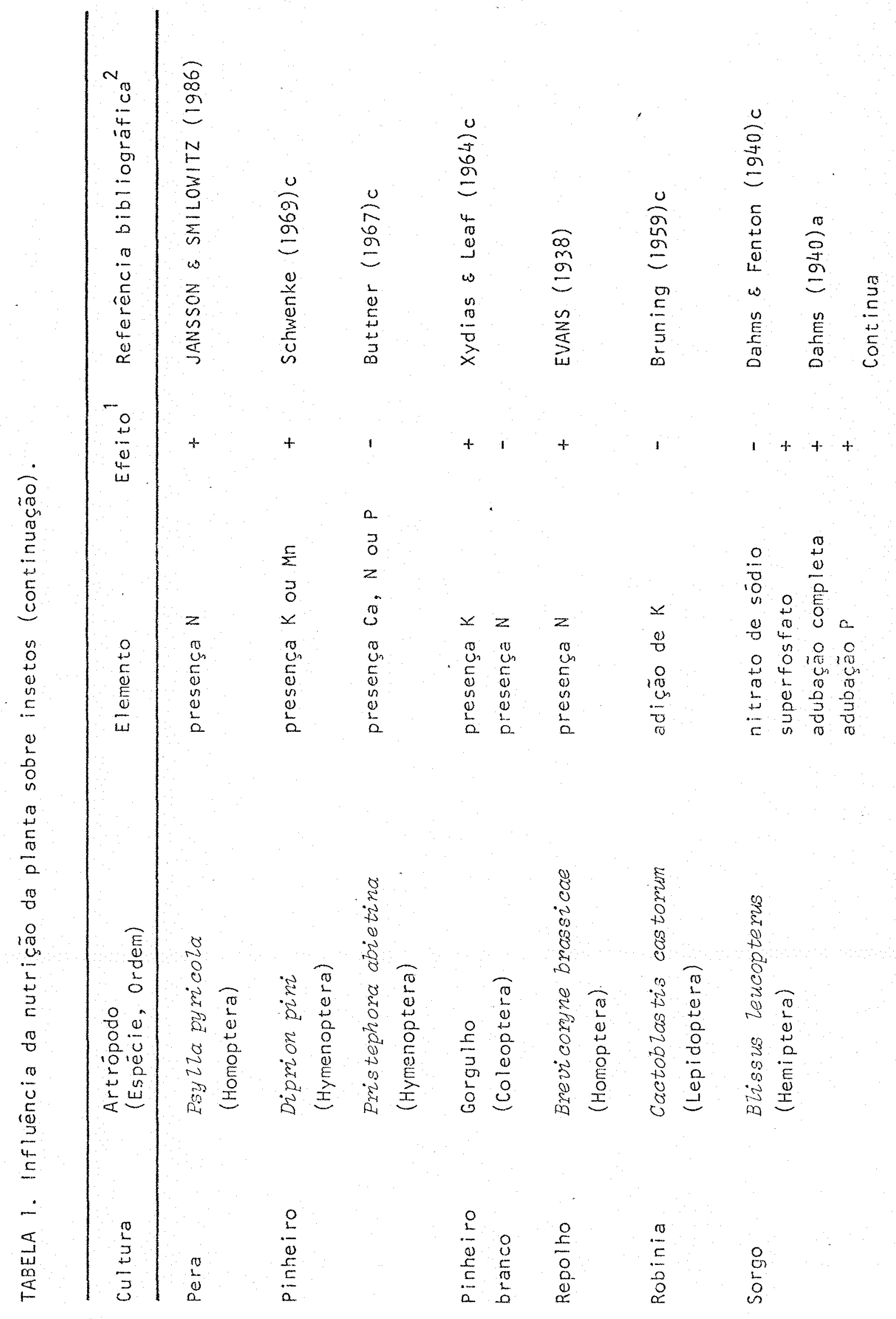




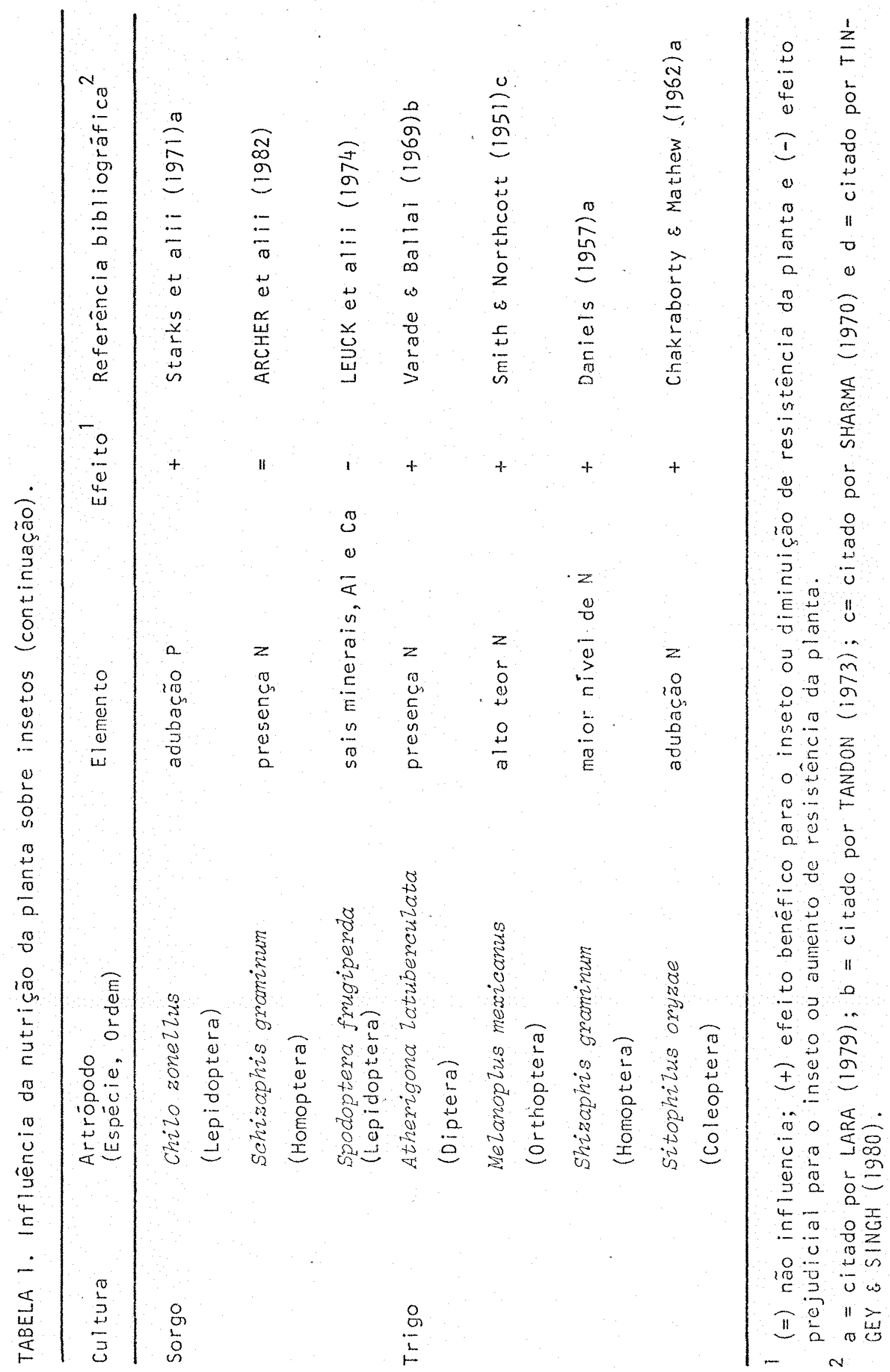




\section{MATERIAL E MÉTODOS}

o presente trabalho fol realizado com Spodoptera frugiperda (J.E. Smith, 1797) (Lepidoptera: Noc tuidae) em mitho (Zea mays L.), no Centro Nacional de Pes quisa de Milho e Sorgo (CNPMS) da Empresa Brasileira de Pesquisa Agropecuäria (EMBRAPA) em Setelagoas, MG (190 $28^{\prime} \mathrm{s}$ e $44^{\circ} 15^{\prime} \mathrm{W}$, altitude $732 \mathrm{~m}$ ) e constou de etapas de campo e laboratörio.

As lagartas utilizadas em ambas as etapas foram provenientes de uma criação mantida em dieta artifi cial (Tabela 2), no Laboratório de Criação de Insetos do Setor de Entomologia do CNPMS.

o estudo de campo fol conduzido em área de cerrado, durante duas safras sucessivas - 1983/1984 e $1984 / 1985$ - utilizando-se o milho híbrido duplo Cargill C111. Os dados de temperatura, unidade relativa do ar e precipitação pluvial, ocorrentes no periodo da pesquisa, foram coletados num posto meteorológico do CNPMS situado a aproximadamente $3 \mathrm{~km}$ do lote experimental.

A outra etapa da pesquisa foi realizada no Laboratörio de Criação de Insetos do CNPMS e embora as 
TABELA 2. Composição da dieta artificial utilizada para criação de S. frugiperda (modificada de PERKINS et ali i, 1973).

\begin{tabular}{lr}
\hline Componentes & Quantidade \\
\hline Feijão & $333,0 \mathrm{~g}$ \\
Levedura de cerveja & $101,4 \mathrm{~g}$ \\
Germe de trigo & $158,4 \mathrm{~g}$ \\
Acido ascórbico & $10,2 \mathrm{~g}$ \\
Metil puhidroxibenzoato & $6,3 \mathrm{~g}$ \\
Acido sórbico & $3,3 \mathrm{~g}$ \\
Agar & $41,0 \mathrm{~g}$ \\
Agua & $2390,0 \mathrm{ml}$ \\
Formaldéido $10 \%$ & $25,0 \mathrm{ml}$ \\
\hline
\end{tabular}

condições ambientais não fossem controladas, a temperatura e umidade relativa foram registradas diariamente através de um termohigrógrafo; a fotofase foi de 14 horas.

3.1. Efeito do Teor de Alumínio do Solo sobre os Danos CAUSADOS pOR S. frugiperda eM MILHO em CONDICÕES DE CAMPO

3.1.1. ANALISE E OBTENĢÃO DOS DIFERENTES TEORES DE ALUMTNIO DO SOLO

Para realização do experimento foi escoIhida uma faixa de solo uniforme quanto à fertilidade, den 
tro de um Latossolo Vermelho Escuro, diströfico, fase cer rado, do CNPMS, sete Lagoas, MG. Para avaliar a uniformidade, essa faixa foi dividida em três partes e cada qual por sua vez, foi novamente dividida em três secções. De cada seção foi retirada uma amostra de solo composta para anàlise em laboratörio.

Essa anälise mostrou haver as seguintes variaçôes: $\mathrm{pH}(4,5$ a 4,7$), \mathrm{Al}\left(1,3 \mathrm{a} 1,4 \mathrm{meq} / 100 \mathrm{~cm}^{3}\right), \mathrm{Ca}$ $\left(0,77\right.$ a $\left.1,09 \mathrm{meq} / 100 \mathrm{~cm}^{3}\right), \mathrm{Mg}\left(0,15\right.$ a $\left.0,24 \mathrm{meq} / 100 \mathrm{~cm}^{3}\right)$, K $(56$ a $63 \mathrm{ppm}), \mathrm{P}(10$ a $16 \mathrm{ppm})$ e matéria orgânica $(3,25$ a $3,45 \%)$. Segundo a COMISSÃO DE FERTILIDADE DO SOLO DO ES TADO DE MINAS GERAIS (1978), não houve diferença de classe de fertilidade para esses elementos e a área foi consi derada uniforme.

Procurou-se então, obter um gradiente de alumínio no solo através da calagem com calcário dolomít co, 20 dias antes do plantio do primeiro ano (safra 83/84) ut ilizando-se duas dosagens 6 t/ha e 2 tha indicadas pelo Setor de fertilidade de Solo do CNPMS e delxando-seuma área sem calcário $(0 \mathrm{t} / \mathrm{ha})$. A quantidade de calcário apli cado em cada parcela visou obter três condições de solo.

a) Solo onde principalmente os teores de a lumínio trocável, cálcio e magnésio estivessem dentro do ideal para cultura (6 t calcärio/ha);

b) solo onde esses teores estivessem aquëm do ideal, mas dentro do limite aceitāvel (2 t calcārio/ ha);

c) solo onde o teor de aluminio fosse to- 
xico para a planta e os de cálcio e magnésio deficientes, em relação às necessidades da cultura (sem calcário).

$$
\text { No decorrer do ensaio foram feitas duas }
$$

outras anālises de solo seguindo a mesma metodologia da primeira safra; assim em $84 / 85$, fol feita uma antes da se meadura e outra na época da infestação artificial pelo in seto.

A extração e determinação dos elementos foram efetuadas segundo VETTORI (1969). O fösforo e a potássio foram extraídos por solução duplo-ācida (mētodo caroIina do Norte) e determinada por colorimetria; o alumínio, cálcio e magnésio trocáveis foram extraídos em solução de KCl 1N. Ocálcio e magnésio, foram determinados por absorção atômica e o aluminio por titulação em $\mathrm{NaOH}$, tendo- se fenolftaleina como indicador.

Uma das premissas básicas do uso da anall se de solo e de sua interpretaçäo é a existência de corre lação entre resultados da anălise química e a resposta de culturas à adubação ou calagem, em condições de campo (RAlJ et alii, 1985). E interessance que a interpretação esteja relacionada com resultados obtidos através de experimentação agronômica na região; assim, neste trabalho, a interpretação dos resultados das anälises de solo feitas após a calagem (Tabelas 3 e 4 ) foi baseada na classificação de teores de nutrientes adotada para mi tho em Mi- nas Gerais pela COMISSÃO DE FERTILIDADE DO SOLO DO ESTADO DE MINAS GERAIS (1978). Segundo o critērio adotado, a ärea experimental mostrou as diferenças desejadas em rela ção a cälcio, magnèsio e a luminio, mantendo-se os teores 
TABELA 3. Análise química do solo da área experimental an tes da semeadura do segundo ano (safra 84/84).

\begin{tabular}{|c|c|c|c|c|c|c|c|c|}
\hline \multirow{2}{*}{$\begin{array}{l}\text { Teor de } \\
\text { alumi- } \\
\text { nio do } \\
\text { solo }\end{array}$} & \multirow{2}{*}{$\begin{array}{l}\text { Calcario } \\
\text { aplicado } \\
\text { na safra } \\
83 / 84\end{array}$} & \multirow{2}{*}{$\begin{array}{c}\mathrm{pH} \\
\mathrm{em} \\
\text { ägua. }\end{array}$} & \multicolumn{3}{|c|}{$\mathrm{meq} / 100 \mathrm{~cm}^{3}$} & \multicolumn{2}{|c|}{ ppm } & \multirow{2}{*}{$\begin{array}{l}\text { Matēria } \\
\text { orgâ- } \\
\text { nica \% }\end{array}$} \\
\hline & & & A 1 & $\mathrm{Ca}$ & $\mathrm{Mg}$ & $k$ & $\mathrm{P}$ & \\
\hline ba $\mathbf{i} \times 0$ & 6 t/ha & 5,1 & 0,2 & 2,75 & 1,20 & 73 & 16 & 3,63 \\
\hline méd io & $2 \mathrm{t} / \mathrm{ha}$ & 4,9 & 0,8 & 1,56 & 0,51 & 70 & 15 & 3,70 \\
\hline alto & $0 \mathrm{t} / \mathrm{ha}$ & 4,7 & 1,3 & 1,03 & 0,20 & 63 & 14 & 3,40 \\
\hline
\end{tabular}

TABELA 4. Anälise química do solo da ärea experimental na. época da interação artificial do segundo ano (safra $84 / 85$ ).

\begin{tabular}{|c|c|c|c|c|c|c|c|c|}
\hline \multirow{2}{*}{$\begin{array}{l}\text { Teor de } \\
\text { alumí } \\
\text { nio do } \\
\text { solo }\end{array}$} & \multirow{2}{*}{$\begin{array}{l}\text { calcário } \\
\text { aplicado } \\
\text { na safra } \\
83 / 84\end{array}$} & \multirow{2}{*}{$\begin{array}{c}\mathrm{pH} \\
\mathrm{em} \\
\text { ägua }\end{array}$} & \multicolumn{3}{|c|}{$\mathrm{meq} / 100 \mathrm{~cm}^{3}$} & \multicolumn{2}{|c|}{ ppm } & \multirow{2}{*}{$\begin{array}{l}\text { Matēria } \\
\text { orgâni- } \\
\text { ca \% }\end{array}$} \\
\hline & & & A 1 & $\mathrm{Ca}$ & $\mathrm{Mg}$ & $k$ & $P$ & \\
\hline ba $1 \times 0$ & $6 \mathrm{t} / \mathrm{ha}$ & 5,2 & 0,15 & 3,19 & 1,38 & 75 & 19 & 3,71 \\
\hline médio & $2 \mathrm{t} / \mathrm{ha}$ & 4,9 & 0,88 & 1,58 & 0,56 & 74 & 19 & 3,74 \\
\hline a) to & 0 t/ha & 4,6 & 1,40 & 1,07 & 0,22 & 79 & 19 & 3,60 \\
\hline
\end{tabular}

de fósforo e potássio mëdios e de matēria orgânica altos em toda a ärea experimental. o teor de nitrogénio não foi avaliado, mas, segundo RAIJ et alii (1985), no que concer 
ne a esse nutriente a anälise de solo não ë eficaz, utili zando-se outros critérios como histórico da gleba e produ tividade esperada. Também para enxofre e micronutrientes, utilizou-se o histörico da área, não sendo feita nenhuma anālise de solo especifica.

Assim, atingiu-se o objetivo, obtendo-se solos com três classes diferentes, no que se refere a cál cio, magnésio e aluminio, mantendo-se os teores de outros elementos uniformes em toda a àrea experimental. Para facilitar o entendimento, no decorrer do trabalho, os solos onde foram aplicados $6 t, 2$ t e onde näo se aplicou calcärio $(0 \mathrm{t})$ foram referidos em função do teor de alumí nio como baixo $\left.(A)=0,15-0,20 \mathrm{meq} / 100 \mathrm{~cm}^{3}\right)$, médio $(A)=$ $\left.0,8-0,88 \mathrm{meq} / 100 \mathrm{~cm}^{3}\right)$ e alto $\left(\mathrm{Al}=1,3-1,4 \mathrm{meq} / 100 \mathrm{~cm}^{3}\right)$ respectivamente, ressaltando-se entretanto, que havia diferença também no teor de cálcio t magnésio, que fol respec tivamente: $\mathrm{Ca}+\mathrm{Mg}=3,95-4,57 \mathrm{meq} / 100 \mathrm{~cm}^{3} ; \mathrm{Ca}+\mathrm{Mg}=$ $2,07-2,14 \mathrm{meq} / 100 \mathrm{~cm}^{3} \mathrm{e} \mathrm{Ca}+M g=1,23-1,29 \mathrm{meq} / 100$ $\mathrm{cm}^{3}$ para $01 \%, 2 \%$ e $3 \%$ tratamentos.

3.1.2. OBTENÇÃO DOS NTVEIS DE INFESTAÇÃO DA CULTURA POR S. frugiperda

Aproximadamente quarenta dias após a semeadura, quando as plantas tinha 8 - 10 folhas, estádio considerado mais suscetivel a $S$. frugiperda (CRUZ \& TURPIN, 1982), foi feita a infestação artificial, colocando- se 30 lagartas de segundo e terceiro instares (baseando-se em anälise visua! e na disponibilidade de la 
40.

gartas), diretamente no "cartucho" da planta com o auxilio de um pincel.

Foram consideradas 40 . plantas por sub-parcela, sendo infestados diferentes números de plantas em função do percentual desejado. Assim, no nível de $0 \%$ não foi infestada nenhuma planta, $20 \%-8$ plantas, $40 \%$ - 16 plantas, $60 \%$ - 24 plantas, $80 \%$ - 32 plantas e $100 \%-$ 40 plantas infestadas.

Das quarenta plantas consideradas, as não infestadas foram mantidas livres de danos através de apli cação periódica de inseticida granulado (Diazinon $14 \mathrm{G}$ ) di retamente no cartucho da planta, através de um dispositi vo tipo "matraca" (CRUz et alii, 1982). Parafacilitar a visualização no campo, essas plantas foram marcadas com uma fita de plástico colorido.

Dezoito dias após a infestação, foi feita uma avaliação contando-se o nümero de plantas com notas 4 (plantas com folhas rasgadas e algum dano no cartucho) e 5 (plantas com o cartucho destruído) segundo una escala visual proposta por CARVALHO (1970) e modificada por CRUZ $(1980)$.

3.1.3. DELINEAMENTO EXPERIMENTAL E CONDUÇÃO DO ENSAIO

o delienamento experimental foi o de blocos ao acaso com parcelas subdivididas com trés repeticöes. Os tratamentos foram os seguintes: 


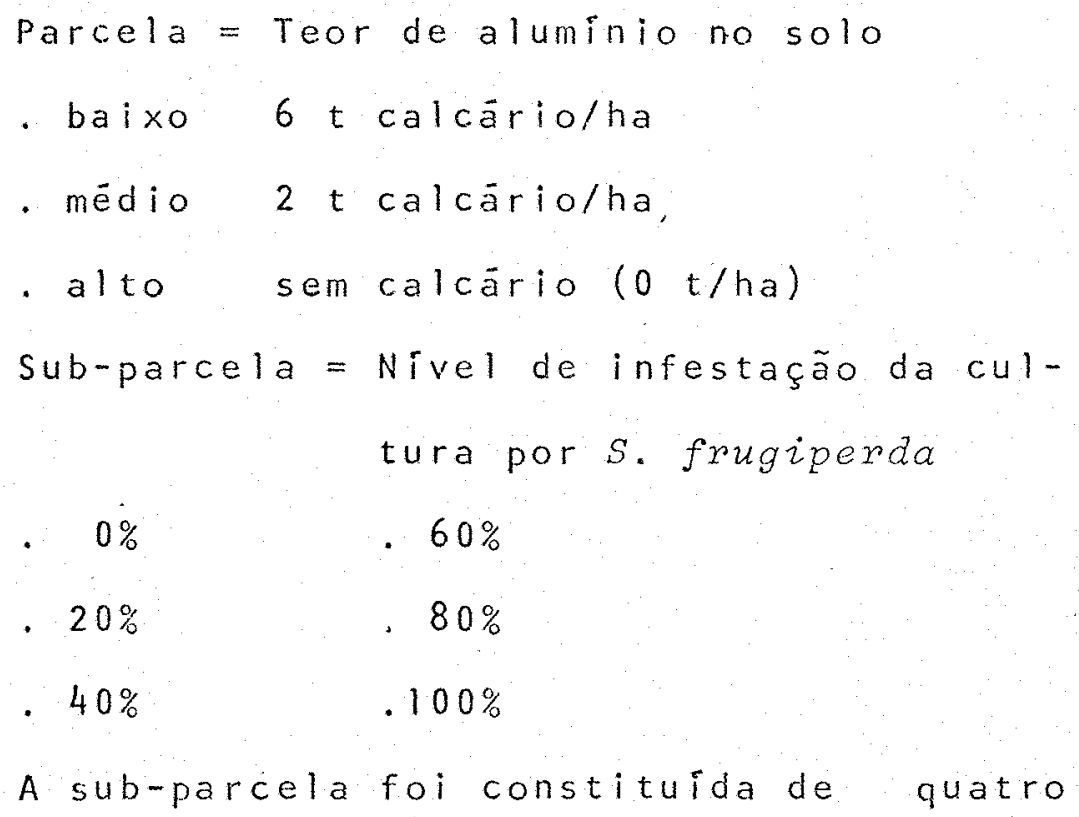

linhas de oito metros, sendo as duas linhas externas consideradas bordaduras. Nas linhas centrais, dois metros de cada extremidade tambem serviram de bordaduras. As 15 plantas consideradas para infestação, de cada subparcela foram identificadas através de etiquetas nu meradas.

o preparo do solo e a semeadura manual fo ram feitos de acordo com as recomendaçóes técnicas para a Região (EMBRAPA/CNPMS, 1982). Trinta dias após o plantio, foi realizado um desbaste, deixando-se cinco plantas por metro de sulco. o controle de plantas daninhas foi feito através de um cultivador com tração animal.

A adubação na semeadura fol feita no sulco (Tabela 5) e a adubação nitrogenada por cobertura $(200$ $\mathrm{kg} / \mathrm{ha}$ de sulfato de amônia) foi realizada 45 dias apōs. 0 experimento foi irrigado por aspersão sempre que necessärio. 
TABELA 5. Adubação utilizada na semeadura do milho

\begin{tabular}{lll} 
Fertilizante & $\mathrm{kg} / \mathrm{ha}$ & Nutriente fornecido \\
\hline sulfato de amónio & 100 & nitrogénio e enxofre \\
superfosfato triplo & 300 & fósforo \\
cloreto de potássio & 100 & potássio \\
sulfato de zinco & 20 & zinco e enxofre \\
\hline
\end{tabular}

\subsubsection{AVALIAÇĀO DA INTERAÇÃO ENTRE TEOR DE} ALUMINIO DO SOLO E DANOS CAUSADOS POR S. frugiperda EM MILHO

A fim de avaliar o efeito do alumínio do solo nos danos provocados por S. frugiperda em milho, observaram-se por ocasião da colheita, os seguintes parâmetros:
a) alturadas plantas;
b) comprimento das espigas;
c) produção em grãos;
d) peso de 100 grãos.

As espigas foram colhidas manualmente, co

locadas em sacos de papel e identificadas com o número da planta de origem. Após o despalhamento, mediu-se o compri mento de cada espiga através de uma régua.

Dentro de cada sub-parcela, as espigas fo ram divididas em dois grupos conforme eram provenientes de plantas infestadas artificialmente ou não infestadas (tra 
tadas com inseticida). Como nem todas as plantas sofreram danos no cartucho, esse grupo foi dividido em dois subgrupos: com e sem cartucho atacado. As espigas de cada grupo foram então debulhadas e pesadas em conjunto, retirando-se então amostras para determinação do teor de umidade, o qual foi realizado conforme normas do Laboratório de Sementes do CNPMS. Posteriormente, o peso foi corrigi do uniformizando-se o teor de umidade para $15,5 \%$. Fol determinado também o peso de 100 grãos para cada grupo.

\subsection{EFeito do TEOR de Aluminio do SOlo sobre A} SELEC,Áo do Millo COMO Hospedeiro por S. frugiperda

Paraverificar se o teor de aluminio do solo influenciava a escolha do al imento pela lagarta, rea lizou-se, na safra 84/85, um teste de livre escolha.

0 delineamento experimental foi intelra mente casualizado com 15 repetições, e cada parcela constou de uma "arena" constituida por uma placa de petri de $20 \mathrm{~cm}$ de diametro, com fundo parafinado e coberto por papel de filtro umedecido com ăgua destilada. En cada pla ca colocaram-se, equidistantes do centro e entre si, trés discos de $9 \mathrm{~cm}^{2}$ de cada tratamento (obtidos com auxilio de um vazador) e no centro uma lagarta de quarto ou quinto instar or iun da de dieta artificial (Tabela 2). os tratamentos foram representados por folhas de milho procedentes de cada nivel de aluminio do solo do ensaio anterior (item 3.1.).

o consumo do alimento, en função da ärea 
foliar, foi medido de 12 em 12 . horas, até a mudança de instar, com auxilio de um medidor de ärea foliar Ll co Rodelo LI-3000. As lagartas foram observadas a cada duas horas, por um periodo de 12 : horas, paraverificar a frequência de alimentação em cada tratamento, a fim de confirmar se as lagartas estavam se movimentando à procura do alimento.

Para corrigir a ärea foliar do alimento que sobrava ("sobras") em função da perda de água, foram utilizadas como testemunhas, placas nas mesmas condiçóes, mas sem a lagarta.

\subsection{Efeito do Teor de Aluminio do Solo sobre a} Biologia e Nutrição Quantitativa de s. frugiperáz em Milho em Condições de Laboratório

Para esse estudo foram utilizadas lagartas recém-eclodidas de $S$. frugiperda de uma mesma postura, que foram individualizadas em copos plásticos de $50 \mathrm{ml}$ (do tipo usado para café) acondicionados com tampa de acrilico transparente (segundo o método de criação normalmente utilizado no CNPMS), contendo pedaços de folla de milho.

As folhas de milho foram provenientes das parcelas do ensaio anterior (item 3.1.). As folhas eran retiradas de cartucho de plantas ao acaso, dentro das bor daduras (duas fileiras externas) das sub-parcelas. Cada nível de alumínio no solo (baixo - 6 t calcário/ha, médio - 2 t calcário/ha e alto - sem calcáriol constituiu um tratamento. 
As folhas que serviram de fonte de alimen to eram lavadas e secas, antes de serem cortadas e oferecidas às lagartas, sendo as extremidades de cada folha desprezadas. 0 alimento era substituido diariamente.

o delineamento experimental foi inteiramente casualizado com 50 e 100 lagartas por tratamento no primeiro ano (safra $83 / 84$ ) e segundo ano (safra 84/85), respectivamente.

\section{3 .1 . BIOLOGIA COMPARADA}

Para esse estudo observou-se a totalidade de insetos do ensaio.

o nümero e duração dos instares não foram avaliados no primeiro ano $(1983 / 84)$, mas no segundo ano $(1984 / 85)$, utilizaram-se 20 lagartas por tratamento pa. ra esse fim, medindo-se diariamente a largura da cápsula cefálica dessas lagartas, através de uma ocular graduada acoplada a um microscópio estereoscópico. o inicio da fase da pré-pupa fol considerado quando as lagartas paravam de se alimentar e as fezes se tornavam mais viscosas.

As pupas foram pesadas com 24 horas de idade. A "sexagem" foi feita visualmente baseando-se nas as as após a emergência do adulto; nos casos onde não havia emer gência, a separação de sexos foi feita na fase pupal (BUTT \& CANTU, 1962).

Após a emergência, foram separados

casais por tratamento, sendo os adultos restantes utilizados para observação da longevidade, permanecendo sem alimento. 
Cada casal (macho e fêmea da mesma idade) foi colocado numa gaiola cilindrica de PVC com $20 \mathrm{~cm}$ deal tura e $10 \mathrm{~cm}$ de diâmetro, com fundo e tampa constituídos, por placas de Petri. No interior de cada gaiola foi colocado um recipiente plästico contendo uma solução de sacarose a $10 \%$ e àcido ascórbico $1 \%$, que era fornecida aos adul tos por capilaridade através de um pavio de algodão que ficava embebido na solução e passava atravēs da tampa per furada do recipiente. Essa solução era trocada diariamente, tempo suficiente para não ocorrer contaminação por mi croorganismos.

Para postura foram colocadas folhas de pa pel sulfite nas paredes internas da gaiola, as quais erar renovadas diariamente.

Cada massa de ovos de cada postura, fo: individualizada em copos plàsticos iguais aos usados para a criação da lagarta. Apōs a eclosão, os copos eram armazenados efreezer (para evitar canibalismo e facilitar a contagem) e posterior mente era feita a contagemdelagartas e ovos restantes com auxilio de um contador manual e papel quadriculado colocado sob uma placa de petri de maneira a delimitar campos de contagem.

Quando não era possivel determinar o sexo dos adultos mortos na gaiola de oviposição apenas por observação externa, procedeu-se a um exame da genitália, sê parando-se os sexos de acordo com a descrição de TOOD \& POOLE $(1980)$.

os paràmetros biolögicos observados foram os seguintes: 
a) Fase de ovo

- duração

- viabilidade

b) Fase de iagarta

- duração

- viabilidade

- número e duração dos instares

c) Fase de prë-pupa

- duração

- viabilidade

d) Fase de pupa

- duração

- viabilidade

- $r a z a ̃ o$ sexual (rs $=\frac{q}{q+\delta}$ )

- peso de pupas

e) Fase de adulto

- longevidade

- período de pré-oviposição

- período de oviposição

- período de pós -ovíposição

- número de dias de postura por fémea

- nümero de ovos por dia por fêmea

- número total de ovos por fêmea

- porcentagem de adultos com defeitos

f) Duração do ciclo ovo-adulto

Como adultos deformados foram considerados aqueles com anormalidades na asa ou que não completavam a emergència. 
S. frugiperda foi feita aplicação do modelo de distribuif̧ão de Weibull, a fim de se obter a longevidade mëdia e o modelo de sobrevivência do inseto adulto (SGRILLo, 1982).

\subsubsection{TABELA DE VIDA DE FERTILIDADE}

A partir dos dados obtidos foi elaborada uma tabela de vida de fertilidade segundo SILVEIRA NETOet alii (1976). Foram calculados os seguintes indices:

a) Taxa liquida de reprodução (Ro)

$$
\text { Ro }=\sum m x \cdot \ell x
$$

b) Duração média de uma geração (T)

$$
T=\frac{\sum n x \cdot \ell x \cdot x}{R_{0}}
$$

c) Capacidade de aumentar em nümero ( $\mathrm{rm}$ )

$$
r m=\frac{\ln R O}{T}
$$

d) Razão finita de aumento ( $\lambda$ )

$$
\lambda=e^{r m}
$$

onde:

$$
x \text { = intervalo de tempo no qual foi tomada }
$$

a amostra;

$$
m x=\text { fertilidade especifica - nümero de }
$$

descendentes produzidos no estägio $x$ por fêmea e que darão fêmeas. Calculado em runção da razão sexual;

$\ell x=$ taxa de sobrevivência - probabilida-

de do inseto nascido estar vivo na idade $\underline{x}$. 


\subsubsection{NUTRIÇÃO QUANTITATIVA}

No primeiro ano da pesquisa $(1983 / 84)$ ut lizou-se a totalidade dos insetos do ensaio (50 lagartas/ tratamerito), mas no segundo ano (1984/85) apenas 40 lagar tas por tratamento foram estudadas do ponto de vista nutricional. o estudo do consumo e utilização de alimento foi feito para toda fase larva!.

As folhas de milho proveniente do solo com três teores de aluminio (baixo, médio e alto) do ensaio de campo, foram fornecidas na forma de discos obtidos com auxillo de um vazador com diâmetro de $3 \mathrm{~cm}$. Diariamente, os discos foliares eram trocados, obtendomse a àrea e o peso das sobras. Tambem foram avaliados o peso das lagar tas e das fezes produzidas.

Todas as pesagens foram realizadas com uma balança eletrónica com precisão de $0,0001 \mathrm{~g}$. A àrea foliar foi medida com um aparelho LI-COR (R) Modelo LI-3000.

\section{$3 \cdot 3 \cdot 3.1$. Anālise quantitativa}

A quantidade de al imento ingerido foi ava liada em função da área e peso de folhas consumidas, medindo-se o alimento fornecido e as sobras após o período de consumo.

Considerando que o peso fresco das sobras não pode ser calculado diretamente, devido à perda de água e acúmulo de outros resíduos durante o tempo que fica 
exposto às larvas (CROCOMO \& PARRA, 1979), optou-se pela obtenção dos dados em peso seco para reduzir os erros.

Para determinação do alimento fornecido ba seou-se no método usado por GARNER \& LYNCH (1981), utilizando-se, como testemunha, dez copos sem lagartas por tra tamento, contendo, porèm, o mesmo nümero de discos oferecidos às lagartas no período.

A àrea e o peso dos discos testemunha eram obtidos antes e depois do periodo de alimentação. Posteriormente, estes discos eram secos em estufa a $65^{\circ} \mathrm{C}$ e novamente pesados. Dessa maneira foi possivel obter a dife rença de àrea e peso devido à perda de ägua.

o peso e à àrea do alimento fornecido foram obtidos multiplicando-se o numero de discos foliares fornecidos pelo peso ou ärea médios dos discos da testemunha.

0 peso seco das sobras foi obtido diretamente, secando-se as mesmas em estufa. A área das sobras era obtida ao fim do periodo de consumo. 0 peso seco do alimento ingerido (1) foi determinado subtraindo-se o peso seco das sobras do peso seco fornecido.

A ärea foliar ingerida (Al) foi obtida pe la seguinte fórmula:

$$
A 1=[A F-(f \cdot A F)-S] \text { onde: }
$$

Al = área do alimento ingerido;

$A F=$ área do alimento fornecido;

$S=a ̈ r e a d a$ sobra de alimento; 
$f=$ fator de correção, calculado em função da variação percentual de ärea no tempo correspondente ao período de consumo em função da perda de àgua.

As fezes produzidas eram recolhidas em um recipiente correspondente a cada lagarta, secas em estufa e pesadas. O recolhimento diārio das fezes produzidas in ciou-se a partir do segundo instar, pois a quantidade pro duzida no primeiro era muito pequena e dificil de ser medida com os equipamentos utilizados na presente pesquisa.

Após a sexta ecdise as lagartas eram pesa das diariamente até atingirem a fase de pré-pupa, obtendo se assim o peso vivo da lagarta no mäximo desenvolvimento $(P \vee L)$.

0 peso seco das lagartas foi determinado através de uma criação paralela, nas mesmas condições, cu jos espécimes foram pesados diariamente após a sexta ecd! se (obtendo-se o peso fresco), mortos por congelamento e postos para secar em estufa até peso constante (peso da matéria seca). A partir desses dados foi obtido um fator de correção para peso fresco das lagartas (SOO HOO E FRAEN KEL, 1966).

o ganho de peso (B) foi obtido subtraindo - se o peso no periodo inicial (to) do peso no período desejado $(t x)$. O peso inicial fol obtido retirando-se una amostra de 50 lagartas recém eclodidas, e pesando-se em conjunto, após terem sido secas em estufa $\left(65^{\circ} \mathrm{C}\right)$. 
$3.3 \cdot 3 \cdot 2$. Indices nutricionais

os indices nutricionais foram calculados a partir dos dados obtidos, conforme WALDBAUER (1968), com alterações propostas por SCRIBER \& SLANSKY Jr. (1981):

- Taxa de consumo relativo (RCR)

$$
R C R=\frac{1}{\bar{B} \times T}
$$

- Taxa metabólica relativa (RMR)

$$
R M R=\frac{M}{\bar{B} \times T}
$$

- Taxa de crescimento relativo (RGR)

$$
R G R=\frac{B}{\bar{B} \times T}
$$

- Eficiência de conversão do alimento ingerido (ECI)

$$
E C I=\frac{B}{1-F} \times 100
$$

- Eficiência de conversão do al imento digerido (ECD)

$$
E C D=\frac{B}{1} \times 100
$$

- Digestibilidade aproximada (AD)

$$
A D=\frac{1-F}{1} \times 100
$$

onde: 
$T=$ tempo de duração do período de alimentação;

$1=$ peso do alimento ingerido $I$;

$B=$ alimento utilizado para o crescimento durante I lganho de peso pelas lagartas);

$\bar{B}=$ peso médio das lagartas durante $I$;

$F=$ alimento não digerido + produtos de excreção durante T:

$M=(1-F)-B=$ alimento metabolizado durante $I$;

$(1-F)=$ alimento assimilado durante $I$.

3.4. Analise Estatistica

os dados foram submetidos à anālise de va riância, sendo as mëdias comparadas pelo Teste de Tukey, ao nivel de $5 \%$ de probabilidade. Quando não havia repeti çôes, recorreu-se a anälise não paramëtrica, utilizando-se - teste de Qui-quadrado para comparação de médias. 


\title{
4. RESULTADOS E DISCUSSÃO
}

\subsection{Efeito do Teor de Alumínio do Solo sobre os Danos CAUSAdOS POR spodoptera frugiperda (J,E. SMITH, 1797) em Milho em Condisões de Campo}

\author{
4.1.1. NTVEIS DE INFESTAÇ̃OA DA CULTURA POR \\ S. frugiperda
}

No primeiro ano (safra $83 / 84$ ) não se conse guiu obter a testemunha sem dano $(0 \%$ de infestação), que mostraria o comportamento da cultura em relação ao teor de aluminio sem a interferência do inseto; optou-se então, por reduzir a subparcela de quarenta para trinta plantas (sen contudo arrancar as plantas) obtendo-se dessa maneira o gradiente de infestação necessário. No segundo ano (84/85), o gradiente obtido fol satisfatörio, sendo consideradas as quarenta plantas por subparcela (Tabela 6$)$.

Para verificar se as diferencas entre a infestação esperada e a obtida representavam alguma influência do teor de aluminio do solo, realizou-se uma anä 
TABELA 6. Porcentagem de plantas de mi tho infestadas por S. frugiperda em solo corrigido para três niveis de aluminio.

\begin{tabular}{|c|c|c|c|c|}
\hline \multirow{4}{*}{$\begin{array}{l}\text { Teor de } \\
\text { aluminio } \\
\text { do solo }\end{array}$} & \multicolumn{4}{|c|}{$\%$ plantas com notas 4 e $5^{1}$} \\
\hline & \multirow{3}{*}{ Esperada } & \multicolumn{3}{|c|}{ observada 2} \\
\hline & & \multicolumn{2}{|c|}{ Safra $83 / 84$} & Safra $84 / 85$ \\
\hline & & $\begin{array}{c}\text { em } 40 \\
\text { plantas }\end{array}$ & $\begin{array}{c}\text { em } 30 \\
\text { plantas }\end{array}$ & $\begin{array}{l}\text { em } 40 \\
\text { plantas }\end{array}$ \\
\hline \multirow[t]{6}{*}{ baixo } & 0 & 6,8 & 0 & 0,0 \\
\hline & 20 & 31,8 & 20 & 20,0 \\
\hline & $\cdot 40$ & 41,8 & 40 & 38,3 \\
\hline & 60 & 62,5 & $\because 60$ & 60,0 \\
\hline & 80 & 82,5 & 80 & 78,3 \\
\hline & 100 & 84,2 & 100 & 96,7 \\
\hline \multirow[t]{6}{*}{ médio } & 0 & 12,5 & 0 & 0,0 \\
\hline & 20 & 33,2 & 20 & 20,0 \\
\hline & 40 & 52,5 & 40 & 40,0 \\
\hline & 60 & 65,8 & 60 & 58,2 \\
\hline & 80 & 79,3 & 80 & 80,0 \\
\hline & 100 & 99,2 & 100 & 99,2 \\
\hline \multirow[t]{6}{*}{ alto } & 0 & 7,5 & 0 & 0,0 \\
\hline & 20 & 25,0 & 20 & 20,0 \\
\hline & 40 & 42,5 & 40 & 40,0 \\
\hline & 60 & 63,2 & 60 & 60,0 \\
\hline & 80 & 75,8 & 80 & 79,2 \\
\hline & 100 & 93,2 & 100 & 97,5 \\
\hline
\end{tabular}

Segundo escala de notas de CARVALHO (1970) modificada por CRUZ (1980).

${ }^{2}$ Não houve diferença significativa pelo teste Qui-quadrado ao nível de $5 \%$ de probabilidade. 
lise dos dados, que mostrou que em nenhum dos anos estudados, o estabelecimento da praga, em função da porcentagem de infestação efetiva da cultura ou intensidade de dano nas folhas, foi influenciada pelo teor de aluminio do solo (Tabela 6).

4.1.2. EFEITO DE S. frugiperda SOBRE PLANTAS DE MILHO EM SOLO CORRIGIDO PARA TRES NTVEIS DE ALUMTNIO

4.1.2.1. Altura da planta

Esse parâmetro só foi avaliado no primeiro ano e verificou-se que as. plantas eram nitidamentemais baixas no solo com maior teor de alumínio não havendo, en tretanto, nenhuma influência ou interação com a porcenta gem de infestação da cultura pelo inseto (Tabela 7 ).

4.1.2.2. Comprimento das espigas

No primeiro ano o comprimento médio das espigas não foi influenciado nem pelo teor de aluminio do solo, nem pela infestação da cultura por S. fmigiperda (Tabela 8 ), mas na safra seguinte as espigas foram menores no solo com alto teor de aluminio (Tabela 9 ).

\subsubsection{Peso de 100 grãos}

o peso dos grãos não foi influenciado pelo inseto em nenhum dos anos. O teor de aluminio do so- 


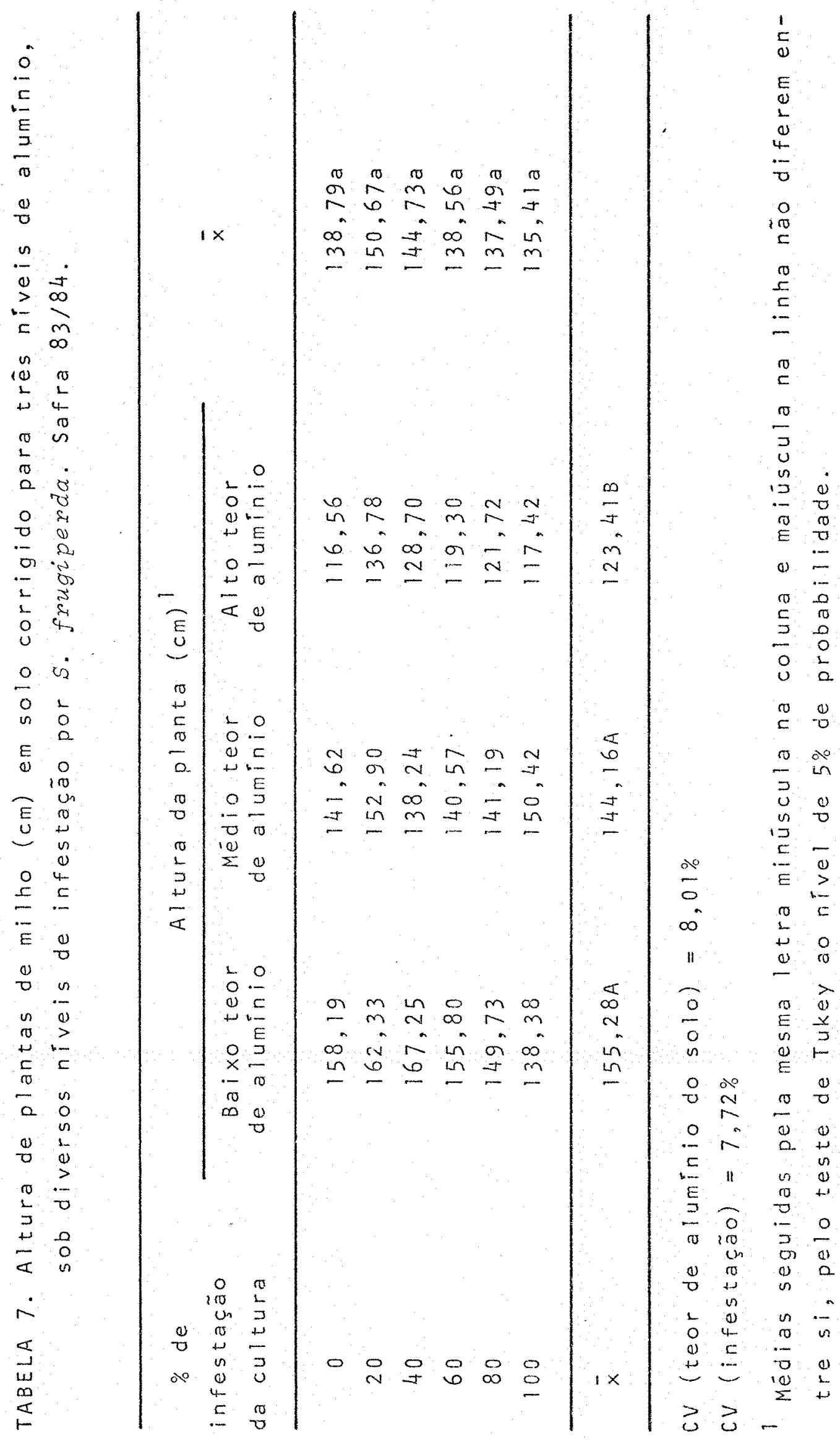


58.

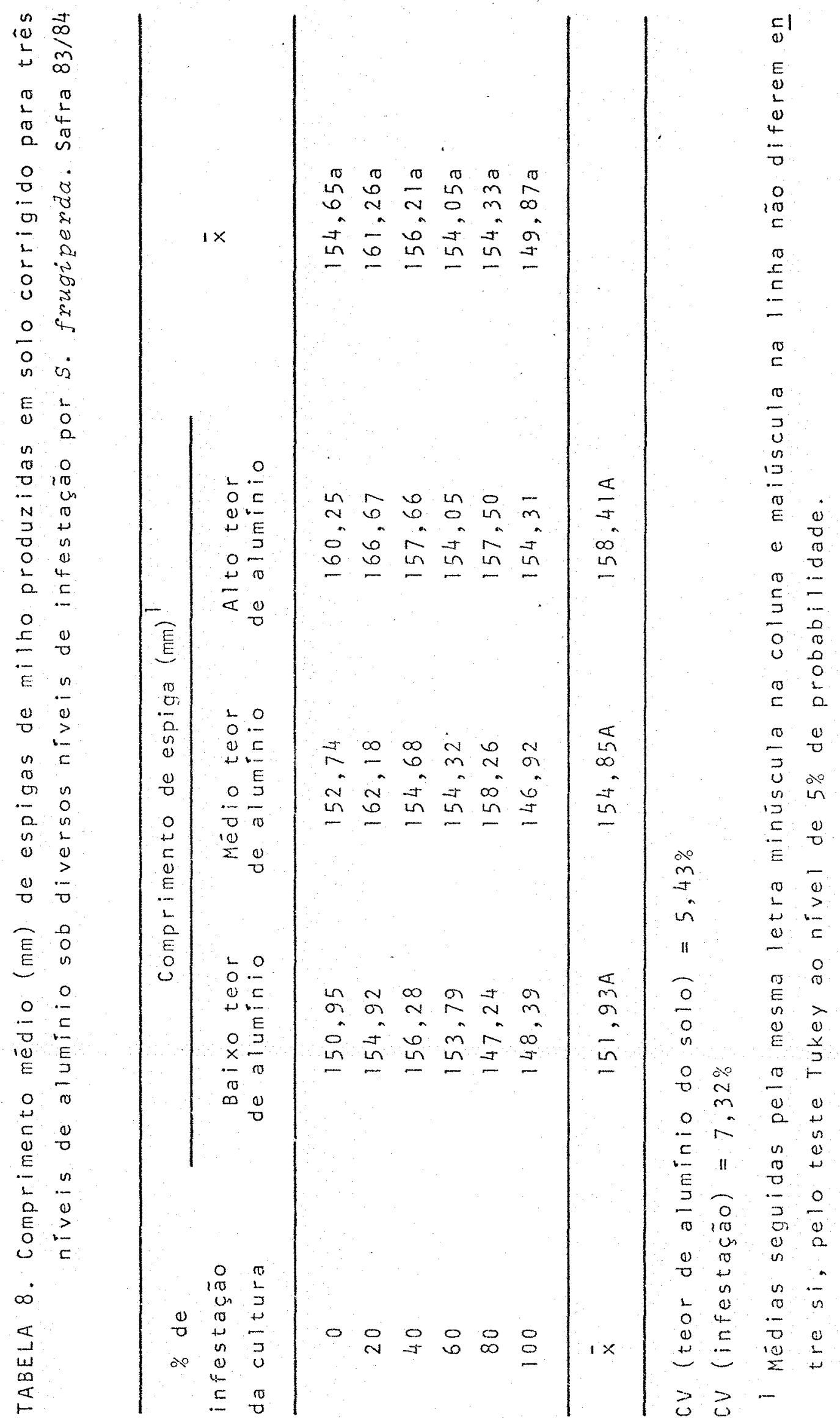


59.

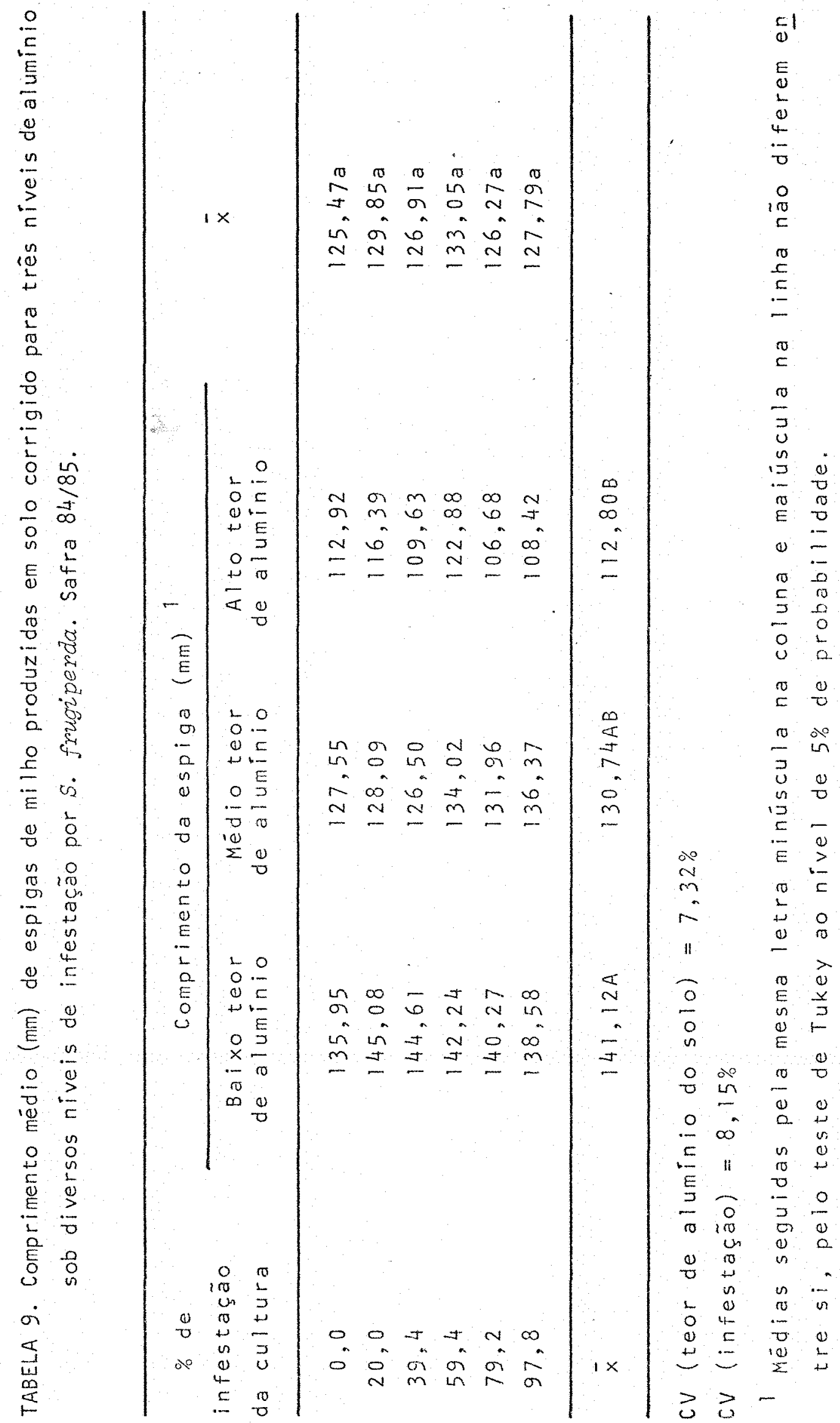


1o, entretanto, afetou significativamente o peso dos grãos. Na primeira safra $(83 / 84)$, o peso de 100 grãos, contrariando o esperado, diminuiu com o teor de alumínio do so10. Na safra $84 / 85$, o peso de 100 grãos esteve inversamente relacionado com teor de aluminio do solo, resul tados estes coincidentes com os de CICERO (1977), que verificou que as sementes de milho eram mais pesadas nas condições de solo ma is favoráveis à planta, embora os nutrientes estudados por esse autor não tentam sido os mesmos do presente trabalho (Tabelas 10 e 11 ).

\subsubsection{Produção de grãos}

No primeiro ano, a produção em grãos não foi afetada pelo teor de aluminio do solo ou pela porcentagem de infestação da cultura (Tabela 12).

Entretanto, quando a produção foi avaliada em termos globais por parcela, comparando-se plantas infestadas e plantas sem infestação, verificou-se que embora não houvesse influência do teor de aluminio do solo na produção, no solo com menor teor as plantas sem infestadas produziram cerca de $42,3 \%$ a menos do que aquela sem infestação pela praga. Nos outros niveis de alumínio, a di ferença de produção entre plantas infestadas e não infestadas, não foi significativa (Tabela 13). A interação en tre danos causados pelo inseto e teor de alumínio do solo não foi significativa.

Cabe ressaltar, que no primeiro ano (safra 83/84) a produção foi baixa em todos os niveis de alu 


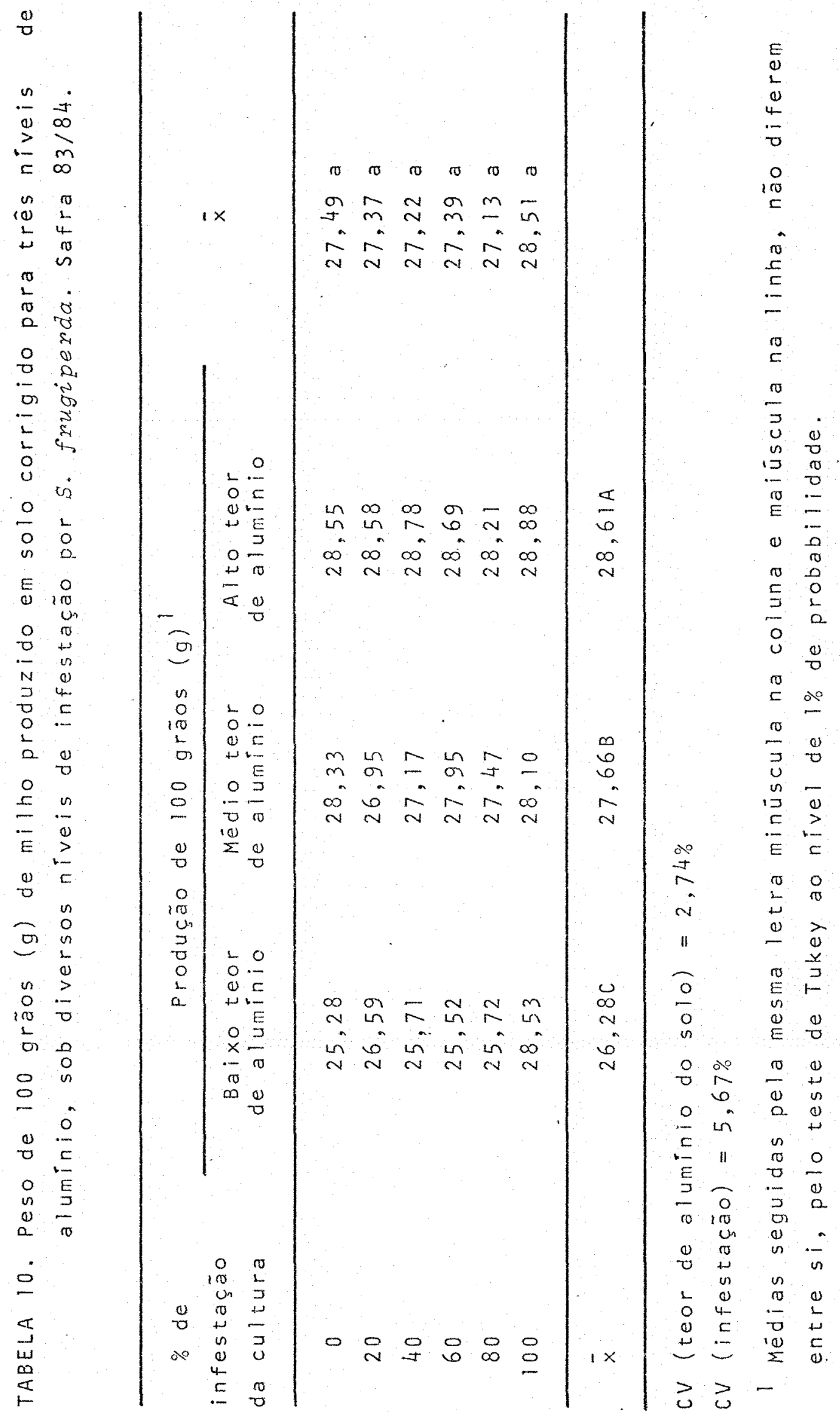


62.

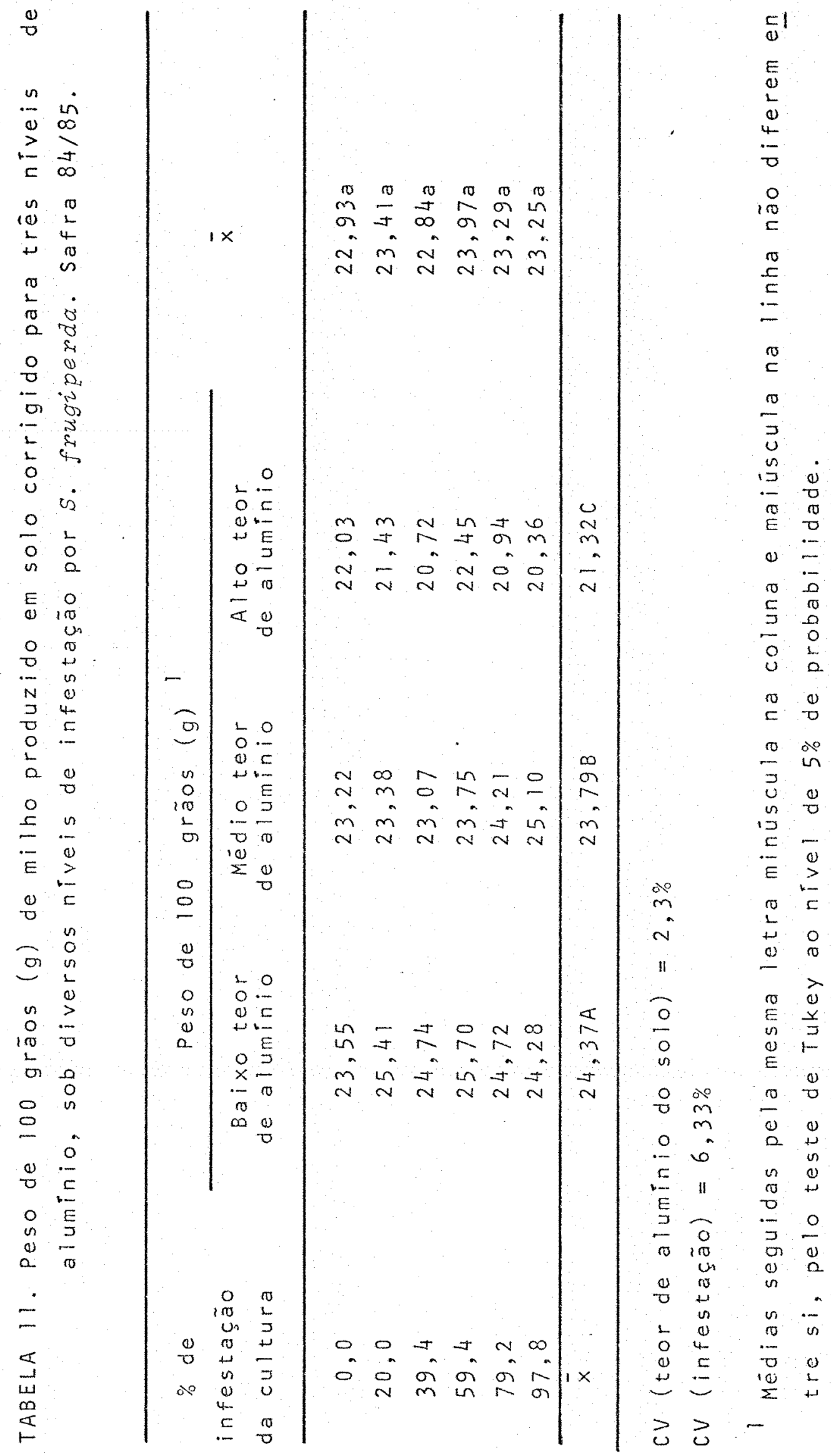


63.

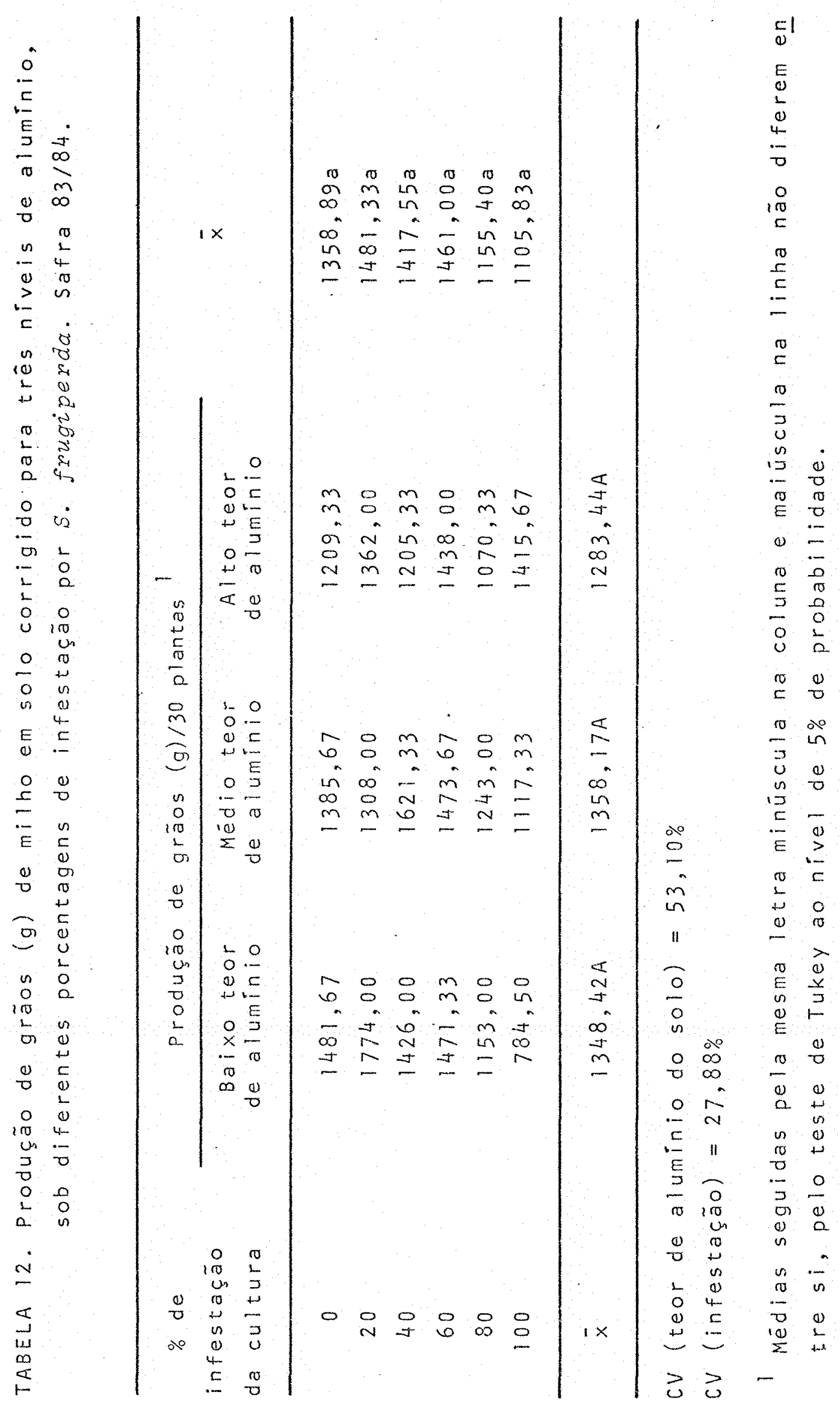


64.

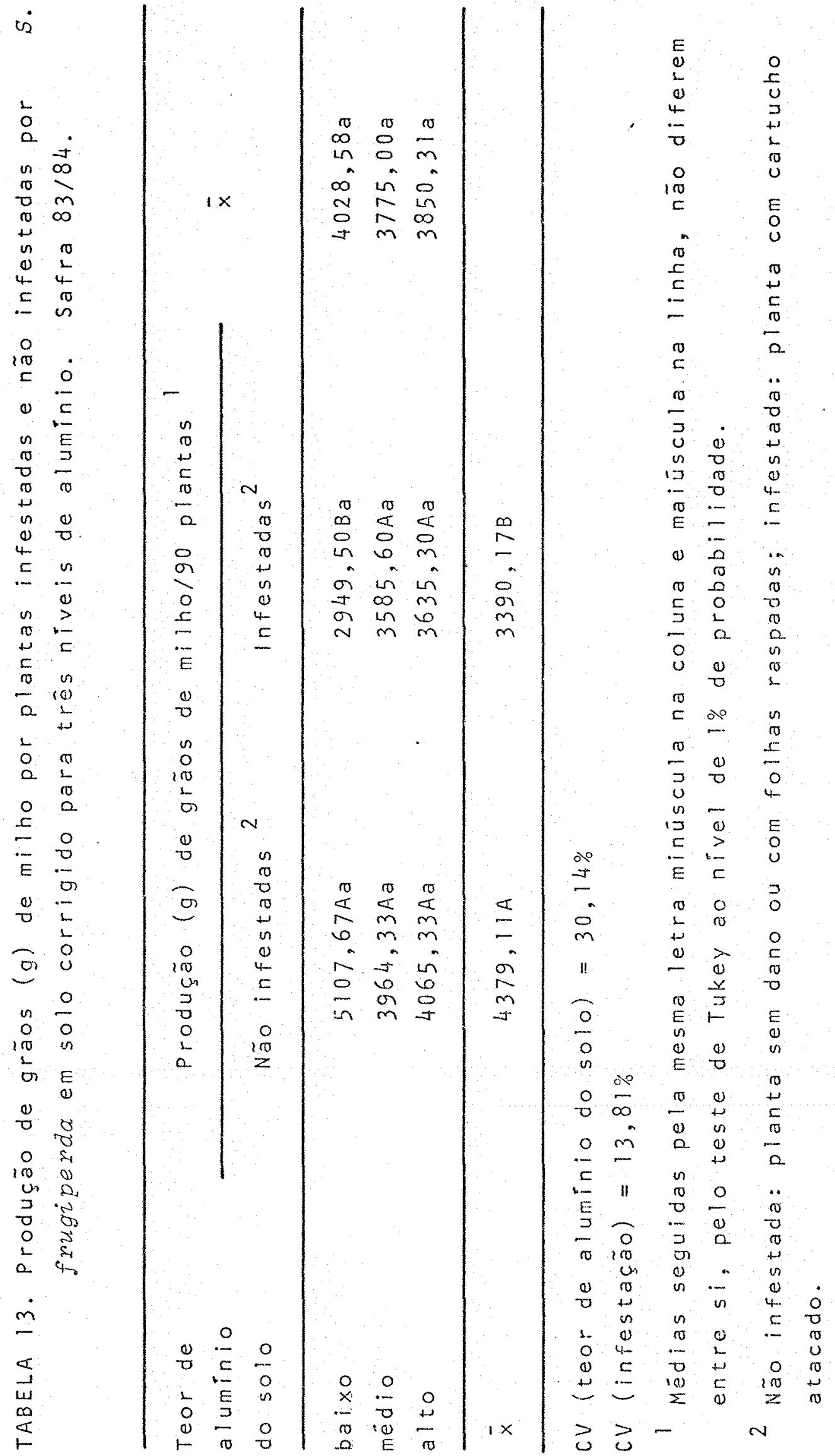


minio do solo, devido principalmente a um veranico ocorri do na época do florescimento (fevereiro de 1984) (Tabela 14), pois embora a cultura fosse irrigada, a àgua disponivel não foi suficiente para satisfazer as necessidades da planta.

No segundo ano, o nível de infestação da cultura não teve qualquer influência na produção total de grãos, que no entanto fol inversamente relacionada com o teor de aluminio do solo (Tabela 15).

Porēm, ocorreu interação entre teor de alumínio do solo e infestação da planta (significativa pe 10 teste de Tukey ao nivel de $6,64 \%$ ), quando a produção foi analisada em termos globais, comparando-se plantas in festadas e sem infestação.

Nos solos com teor de aluminio baixo e mé dio, a produção das plantas não infestadas foi significativamente superior que as infestadas; no solo com alto teor de alumínio, a produção das plantas com e sem infestação foi semelhante. Observou-se que a produção das plan tas sem infestação foi maior conforme se diminuía o teor de alumínio do solo; jä em relação às plantas infestadas, a produção nos solos com baixo e médio teor de aluminio foi semelhante, diferindo, entretanto, do solo com alto teor onde a produção foi significativamente menor (Tabela 16). 


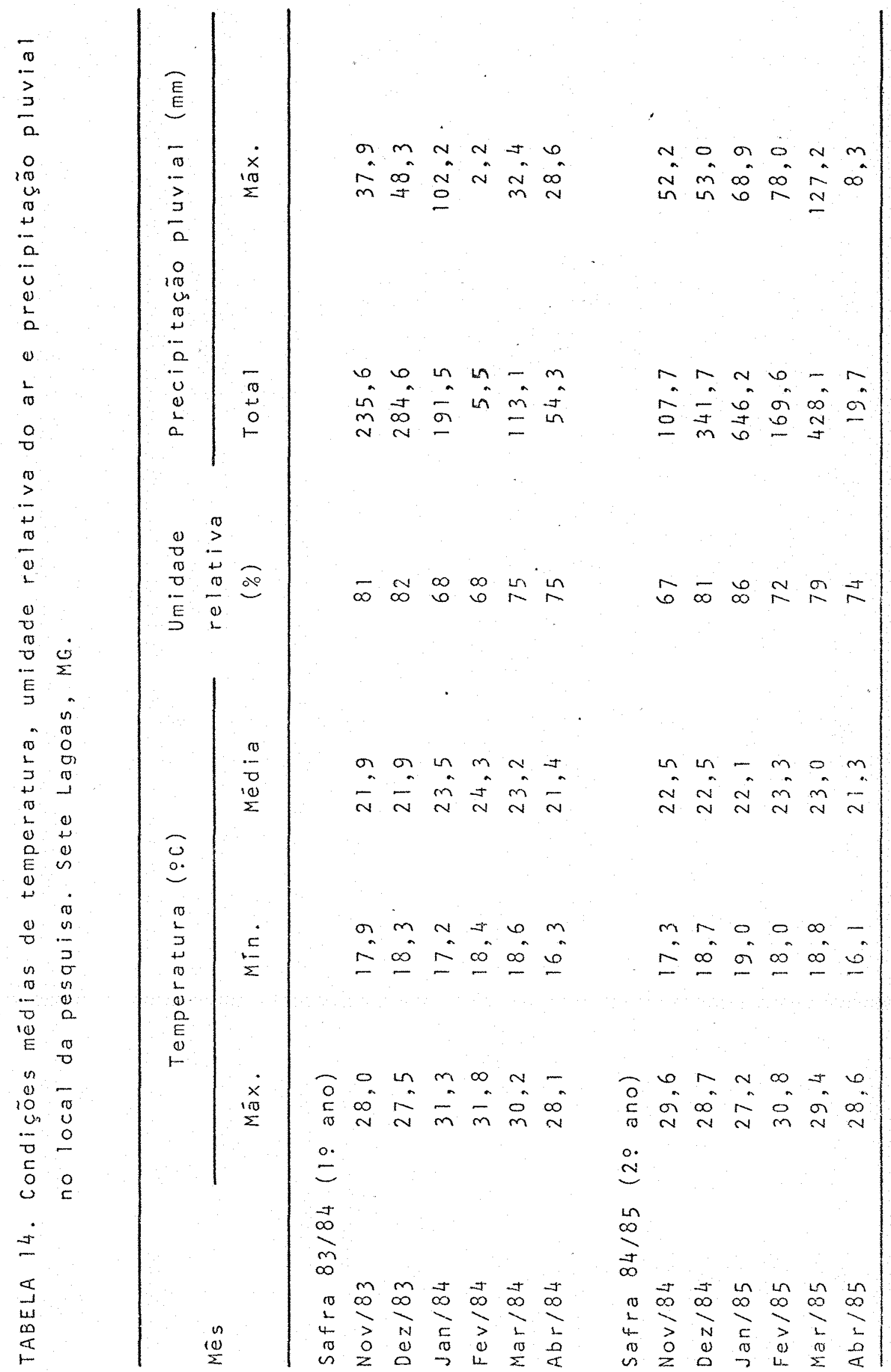




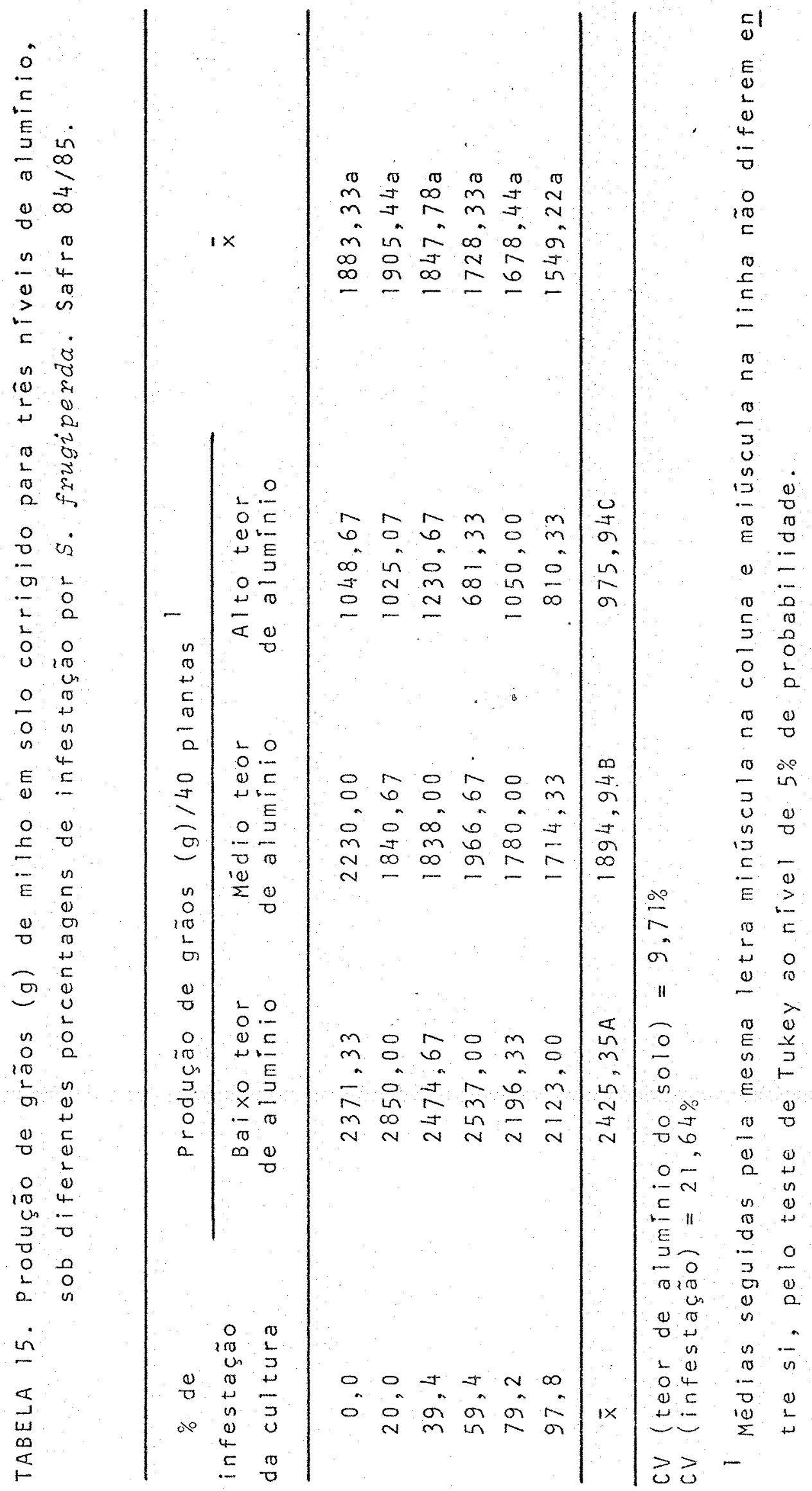




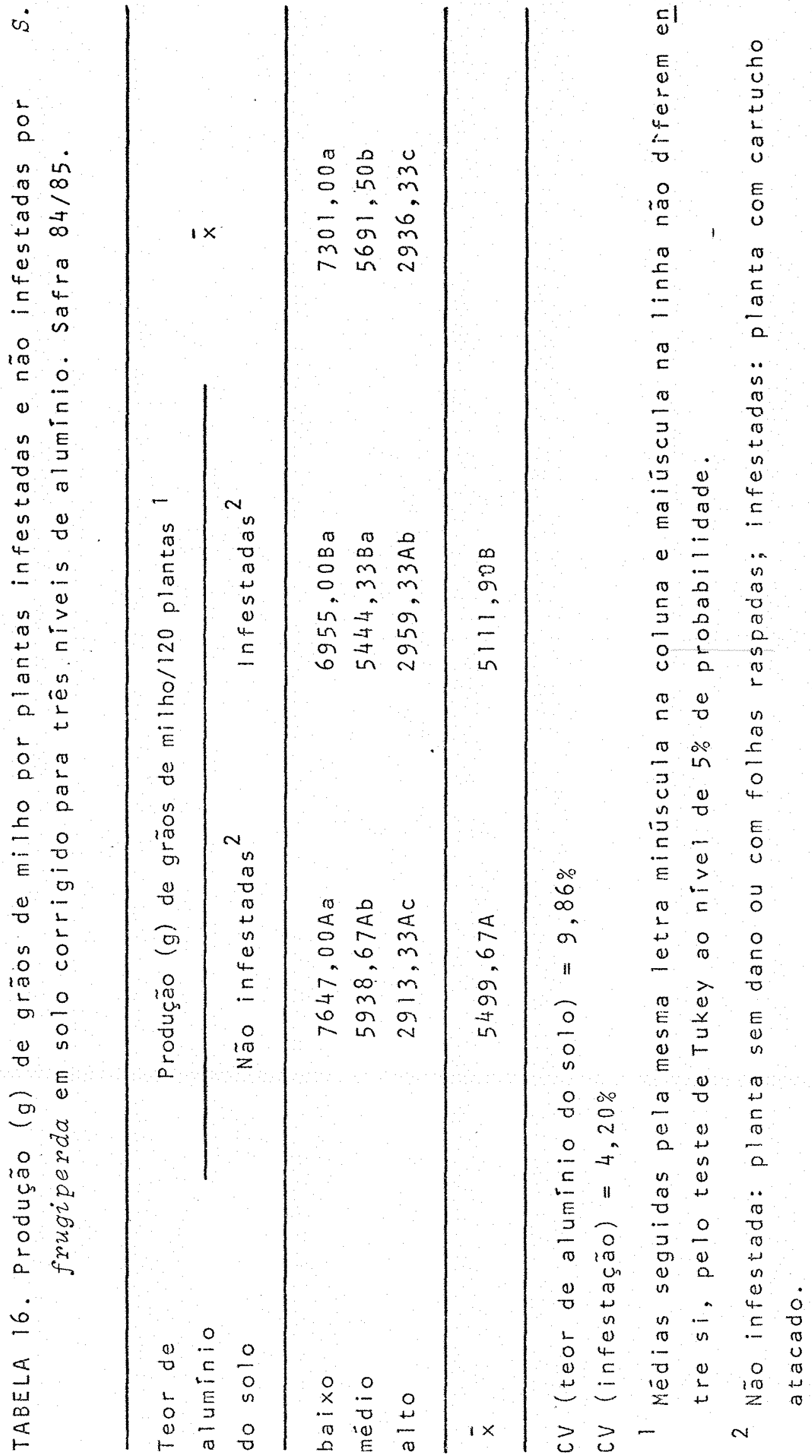


4.1.3. CONSIDERAÇÕES GERAIS SOBRE O EFEITO DA INTERAÇÃO "DANOS CAUSADOS PELO INSETO TEOR DE ALUMTNIO" SOBRE A PLANTA

Uma anälise geral dos dados, mostra que houve alguma influência do teor de alumínio do solo sobre os danos causados por $S$. frugiperda, mas esta só pôde ser avaliada quando se compararam plantas atacadas e não atacadas pelo inseto, não sendo a porcentagem de plantas infestadas na cultura um bom parâmetro de avaliaçäo para es se estudo.

CLAVIJO (1984) tambëm verificou que a por centagem de infestação não afetou a produção de millho em värios níveis de adubação nitrogenada.

A intensidade do efeito prejudicial de $S$. frugiperda sobre a produção de grãos de milho, tambëm não foi constante, sendo bem maior quando o ano foi seco, con firmando as observações de LEIDERMAN \& SAUER (1953) e MENS choy (1956), embora nesse caso, somente no solo com bai $x$ o teor de alumínio, a influência do inseto tenha sido constatada. No segundo ano, quando as condições climáticas foram mais favoráveis às plantas, somente no solo com alto teor de aluminio o ataque do inseto não afetou a produção.

Estes dados refletem apenas uma tendência, sendo necessärios novos estudos, onde outros parâmetros sejam incluidos com o objetivo de verificar a influêricia do inseto sobre a planta, isolando-se fatores ambientais, tais como temperatura e umidade, atravēs de ensaios em casa de vegetação. 


\subsection{Efeito do Teor de Aluminio do solo sobre}

a Selegão do Milho como Hospedeiro

POR S. frugiperda

Não houve influência do teor de alumínio do solo na seleção das folhas de milho pelas lagartas. En tretanto, o coeficiente de variação foi muito alto $(68,14 \%)$, - que pode ser atribuido à variação individual das lagartas. Com intuito de minimizar essa variação individual, calculou-se um indice de preferencia relativa (ärea foliar consumida em cada tratamento em relação ao total ingerido por placa), mas mesmo assim a variação foi alta $(65,66 \%)$ näo havendo diferenças entre os tratamentos (Tabela 17).

Devido à grande variação registrada, suge rem-se estudos com lagartas recém-eclodidas ou lagartas de diferentes instares para se calibrar a metodologia des te tipo de estudo. Desta forma, a tendencla observada das lagartas consumirem maior ärea foliar nos solos com altos teores de aluminio (Tabela 17) talvez possa ser detectada, desde que haja um menor coefictente de variação (cV).

4.3. Efeito do Teor de Alumínio do Solo sobre A Biologia e Nutrigão Ruantitativa de $S$. frugiperda em Milho e em Condigões de Laboratório

As condições ambientais médias durante es 
se estudo foram de $26,1 \pm 1,1^{\circ} \mathrm{C}$ e $70 \pm 5,4 \%$ de umidade re lativa no primeiro ano e de $27,5 \pm 1,4^{\circ} \mathrm{C}$ e $77 \pm 4,2 \%$ de umidade relativa no segundo ano. A fotofase foi de catorze horas em ambos os anos.

\subsubsection{BIOLOGIA COMPARADA}

4.3.1.1. Fase de ovo

A fase de ovo só foi observada na safra 84/85. Essa fase não foi afetada pelo teor de alumínio do solo, durando cerca de três dias em todos os niveis: A viabilidade foi sempre superior a $80 \%$, não sofrendo também influência do teor de aluminio do solo (Tabela 18).

\subsubsection{Fase de lagarta}

A fase larval durou em média 13,70

14,26 dias e foi afetada pelo teor de alumínio do solo. Assim, foi mais curta quando as lagartas foram al imentadas com folhas procedentes do solo commenor teor de aluminio. En tretanto, no primeiro ano, houve diferença significativa apenas entre os solos com teor de aluminio baixo $\epsilon$ médio e no segundo ano, essa diferença ocorreu entre os solos com baixo e alto teor de aluminio. A viabilidade larval 
72.

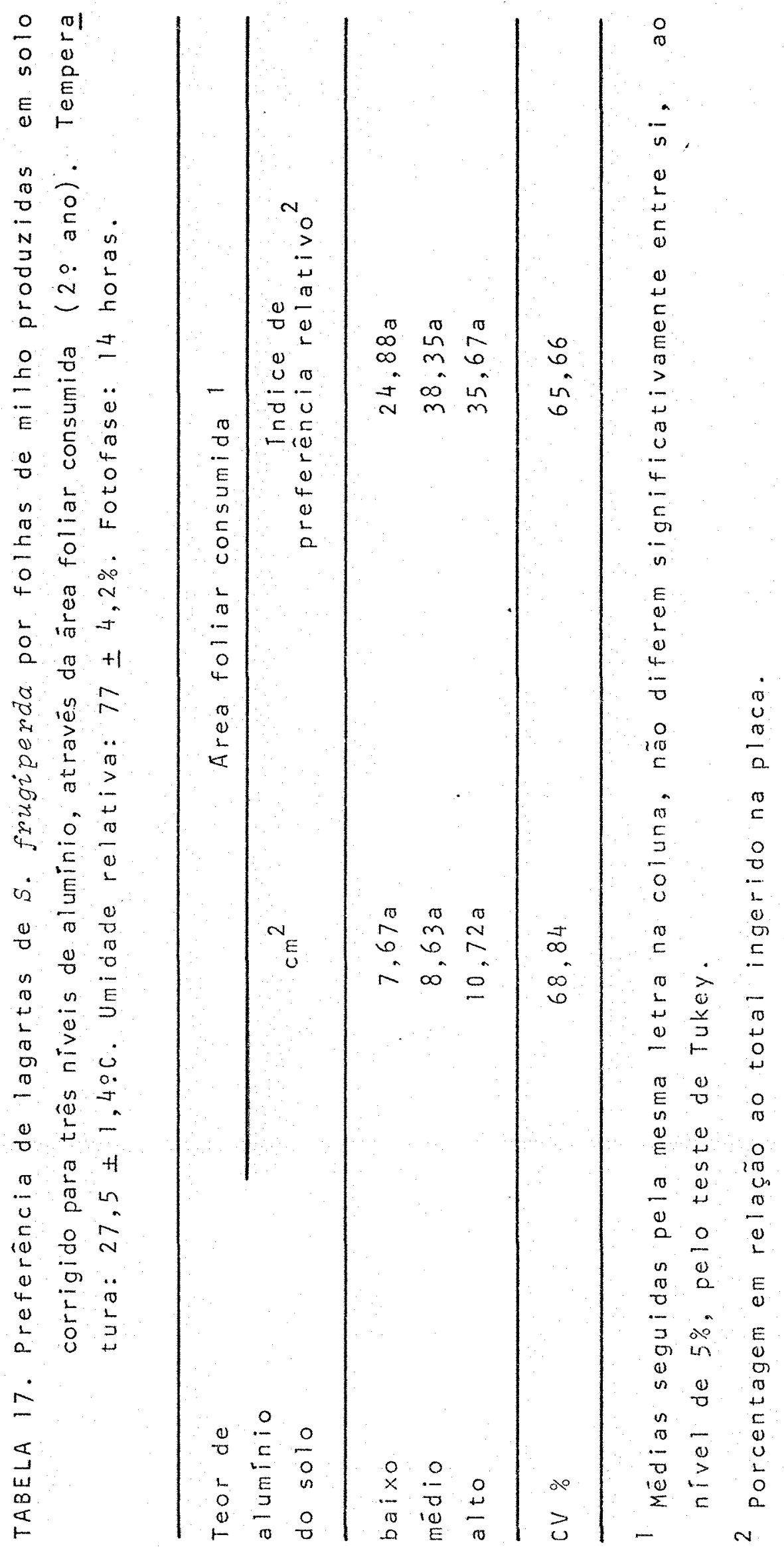




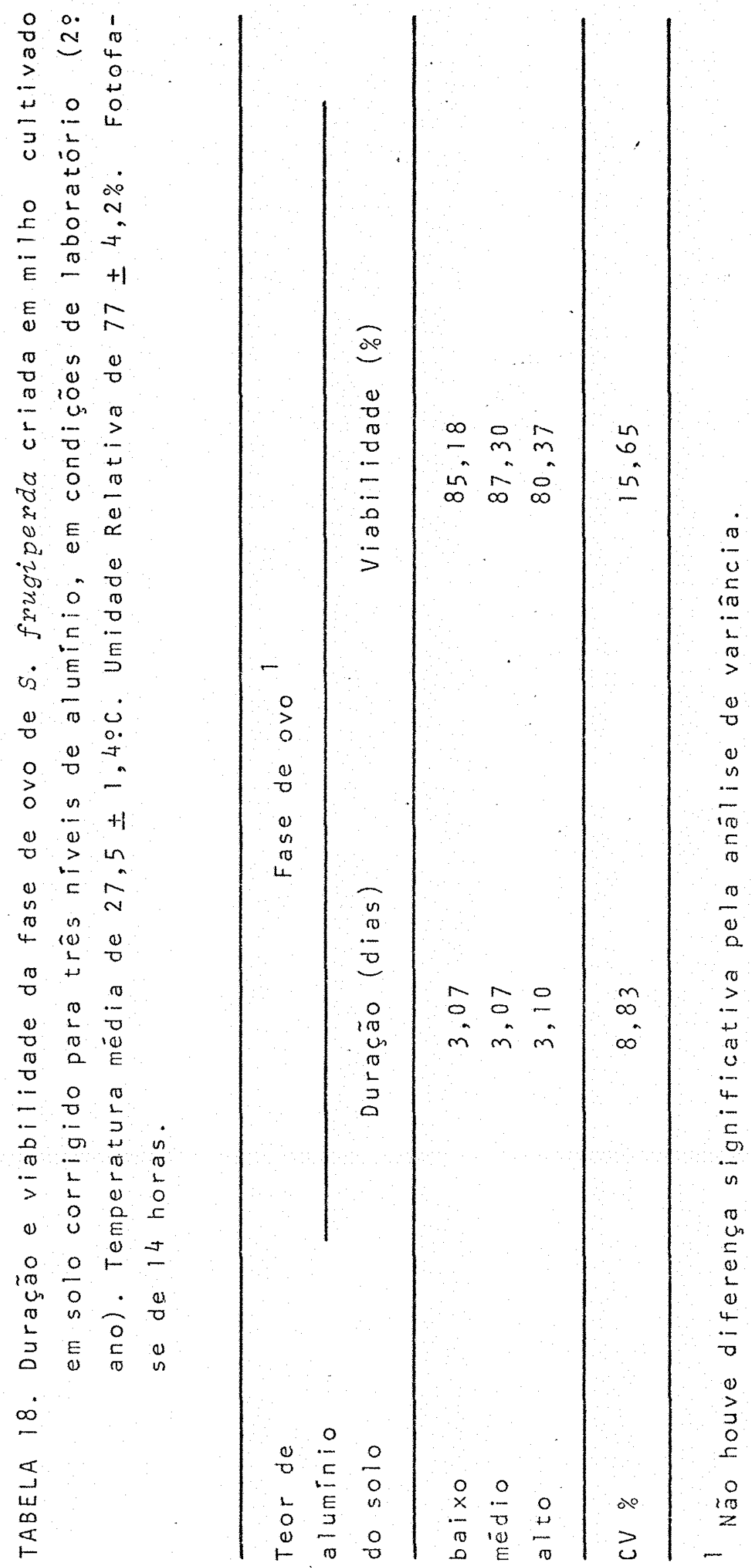


não foi afetada pelo teor de aluminio do solo, sen do sempre superior a $90 \%$ em todos os niveis de aluminio (Tabela 19).

o nümero de ínstares não foi afetado pelo teor de alumínio do solo. No solo com alto e baixo teor de aluminio, $100 \%$ das lagartas apresentaram sete instares e no solo com teor de aluminio médio, cerca de $85 \%$ apresentaram sete e $15 \%$ apresentaram seis instares, sendo nesse caso o ültimo instar mais longo. Em todos os trata mentos, a razão de crescimento obedeceu a regra de DYAR (1890), ou seja, foi em média 1,4 (Tabela 20 ).

o quarto instar foi significativamente mais longo nos solos com teor de aluminio médio e alto, sendo portanto, aparentemente o instar mais sensivel às variaf̧ões nos teores dos elementos minerais do solo analisados e que poderá servir, então, como padrão para esse tipo de estudo (Tabela 20).

4.3.1.3. Fase de pré-pupa

A duração e viabilidade da fase de prépupa não foram afetadas pelo teor de aluminio do solo. Essa fase durou em média de 1,27 a 2,00 dias. No primeiro ano, a viabilidade foi baixa (menor que $72 \%$ ) em relação ao segundo $(100 \%)$ em todos os niveis (Tabela 21 ). Todas as pré-pupas mortas apresentavam um sintoma caracterí tico de endurecimento e pigmentação castanha do tegumento; entretanto a causa dessa mortalidade não pôde ser de terminada. 


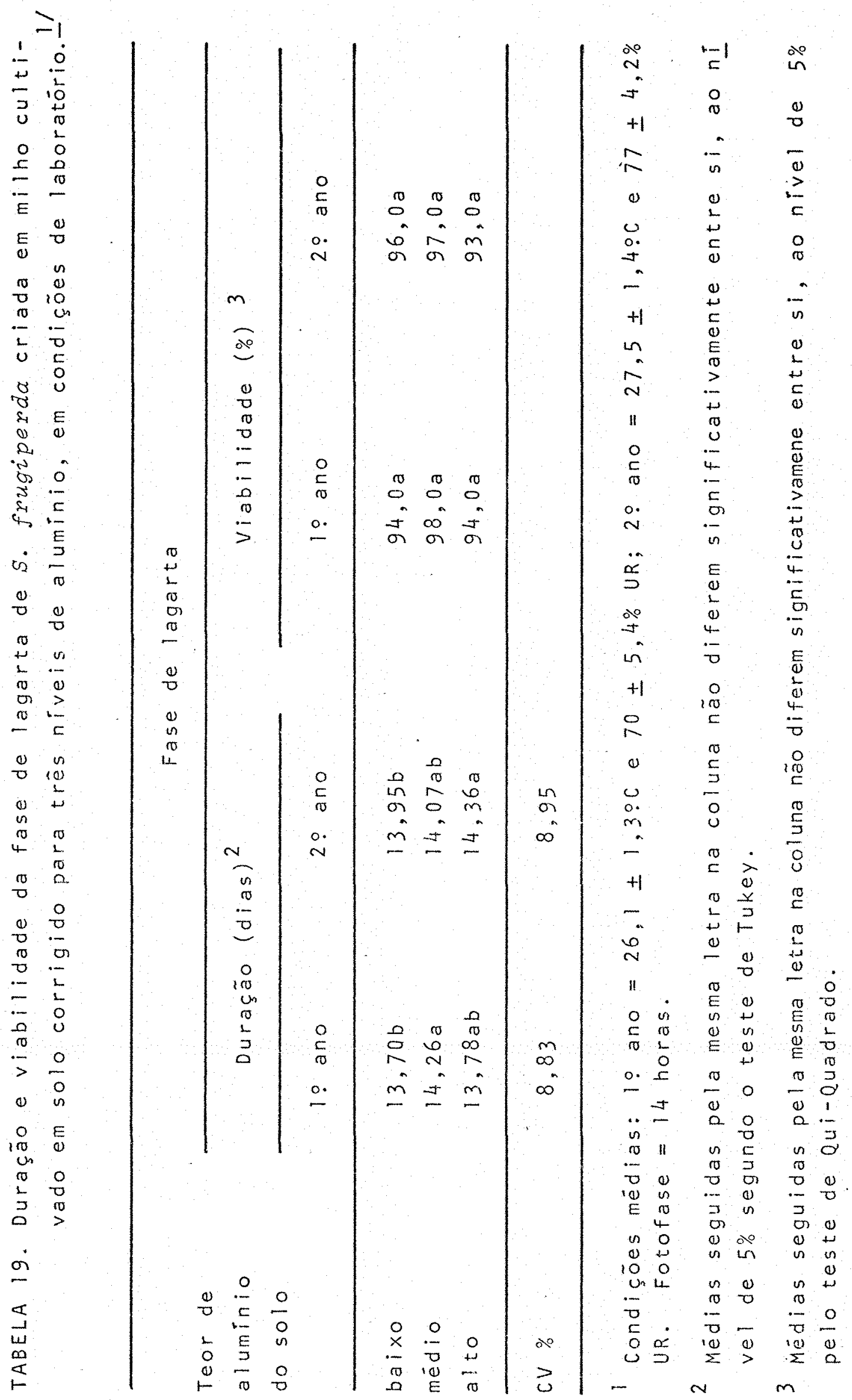




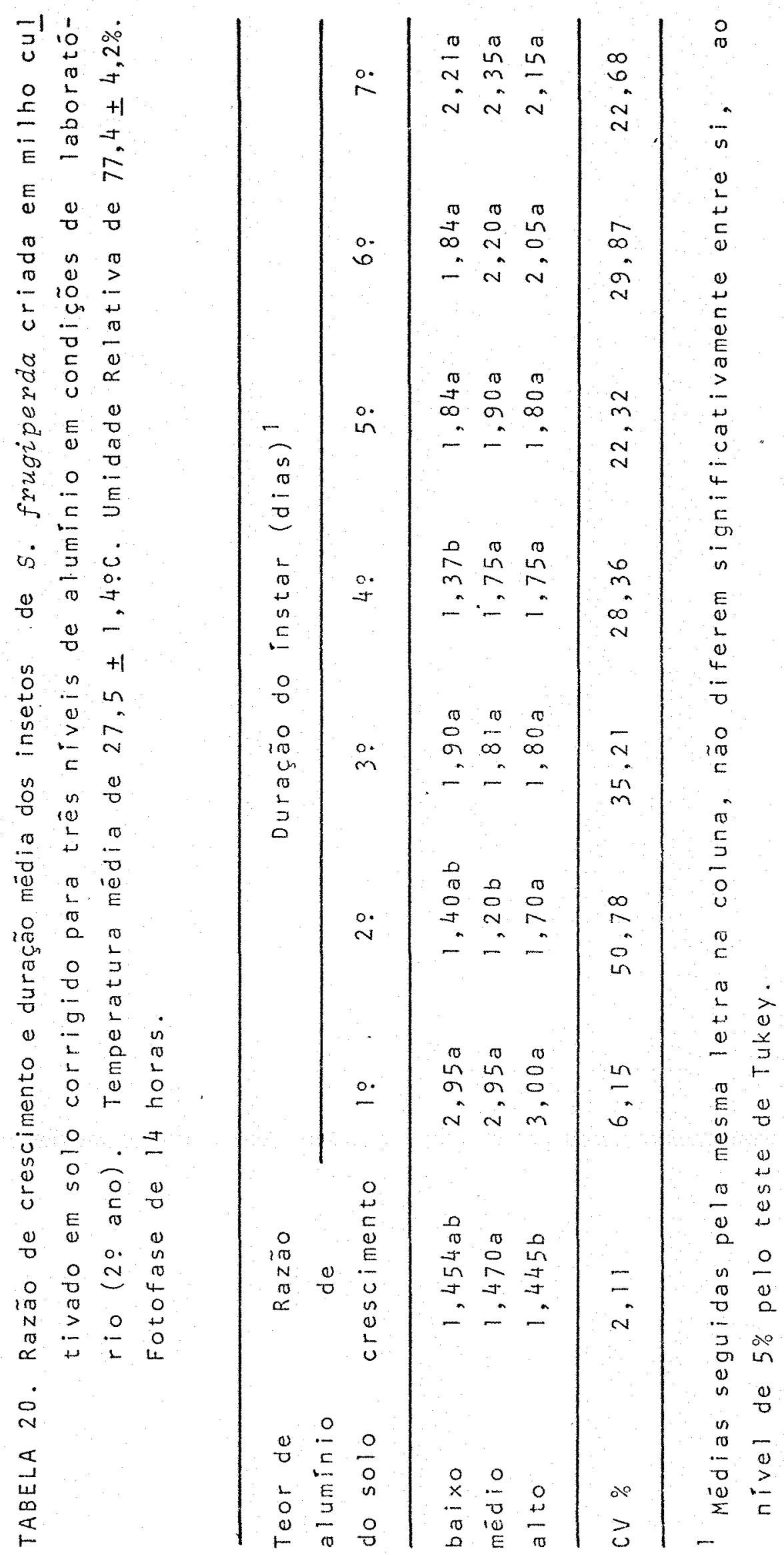




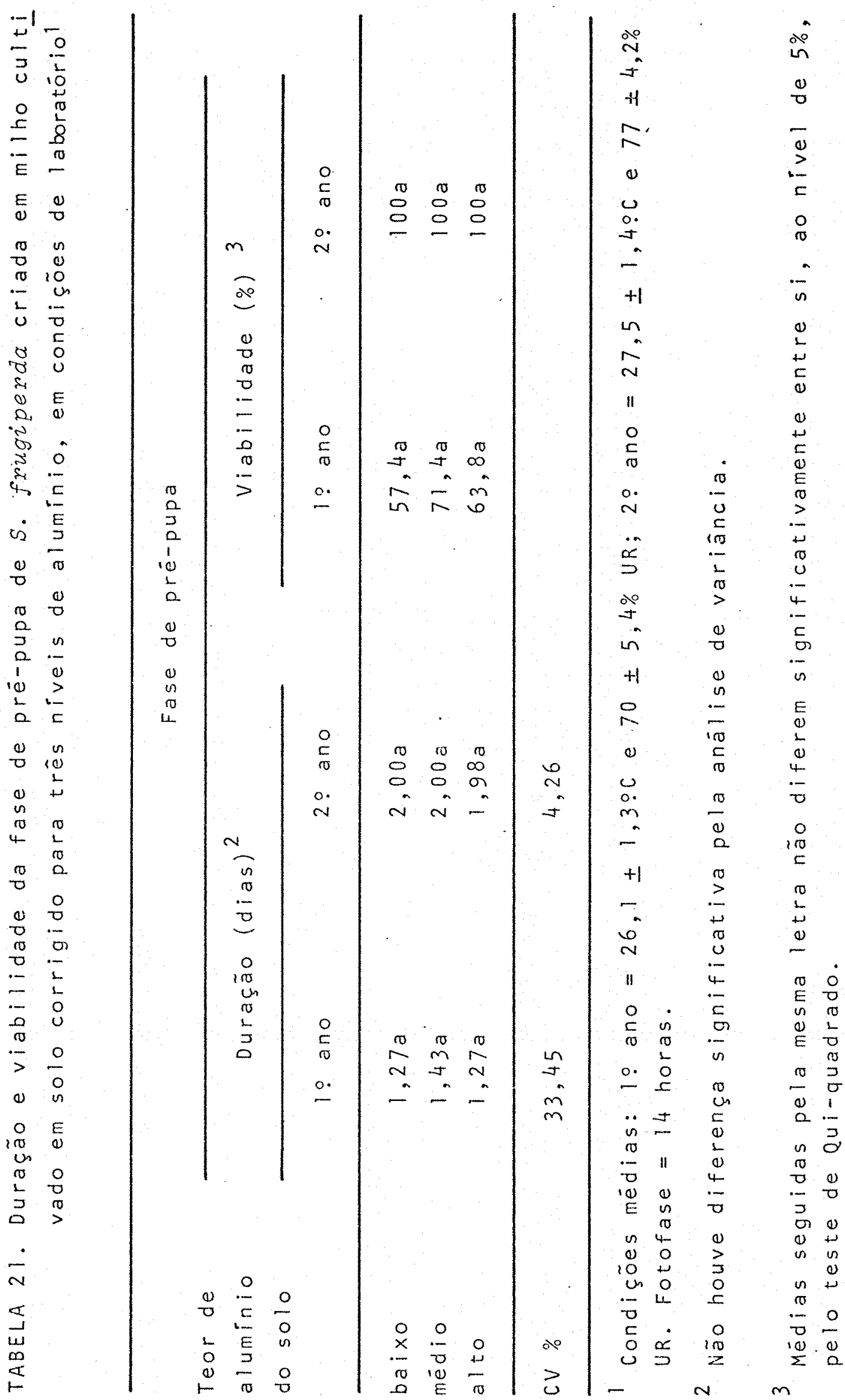




\subsubsection{Fase de pupa}

No primeiro ano, a duração, da fase pupal

não sofreu nenhuma influência do aluminio do solo, varian do de 8,87 a 9,06 dias para fêmeas e de 9,78 a 10,29 dias para machos. No segundo ano, observou-se que houve efeito do teor de alumínio do solo sobre essa fase e tanto para machos como para fêmeas a duração foi menor no solo con teor médio, embora no caso das fêmeas essa diferença só tenha sido significativa entre os teores de aluminio médio e alto (Tabela 22).

- peso das pupas também não foi afetado pelo teor de aluminio do solo no primeiro ano, e no seguinte só houve efeito do solo para as pupas de machos que foram mais leves no solo com teor de aluminio médio em ré lação aos demais (Tabela 23). Em termos gerais poder-se. ia dizer que o aluminio não afetou a fase pupal de $S$ fra giperá.

A viabilidade média dessa fase foi igual ou superior a $90 \%$ em todos os níveis estudados. A razão sexual foi 0,$64 ; 0,60$; e 0,66 no primeiro ano e 0,$54 ; 0,52$ e 0,46 no segundo ano, nos solos com teor de alumínio bai xo, mëdio e alto respectivamente (Tabela 24), mostrando que ambos os sexos foram igualmente afetados pelos teores de alumínio. 


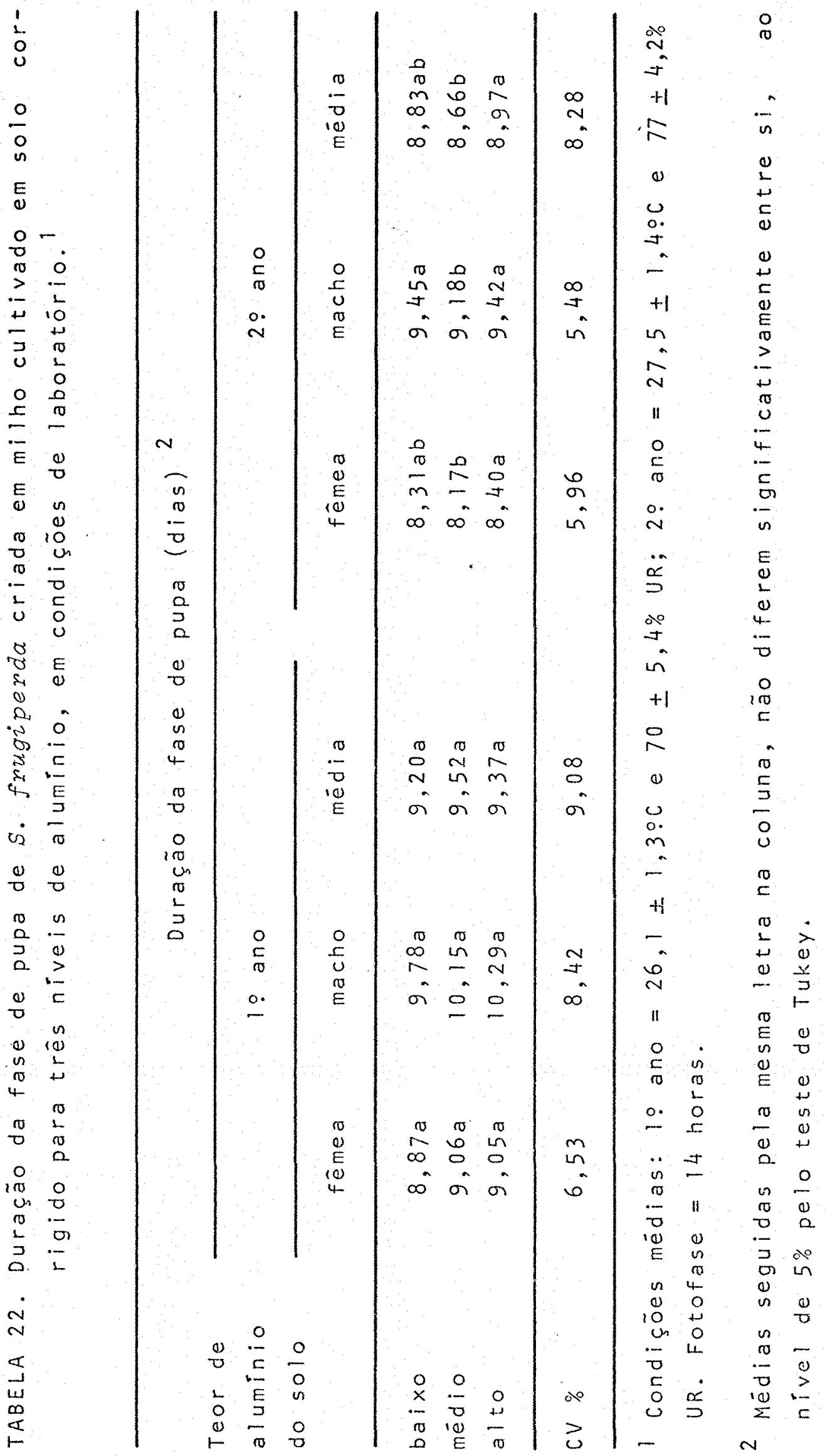


80.

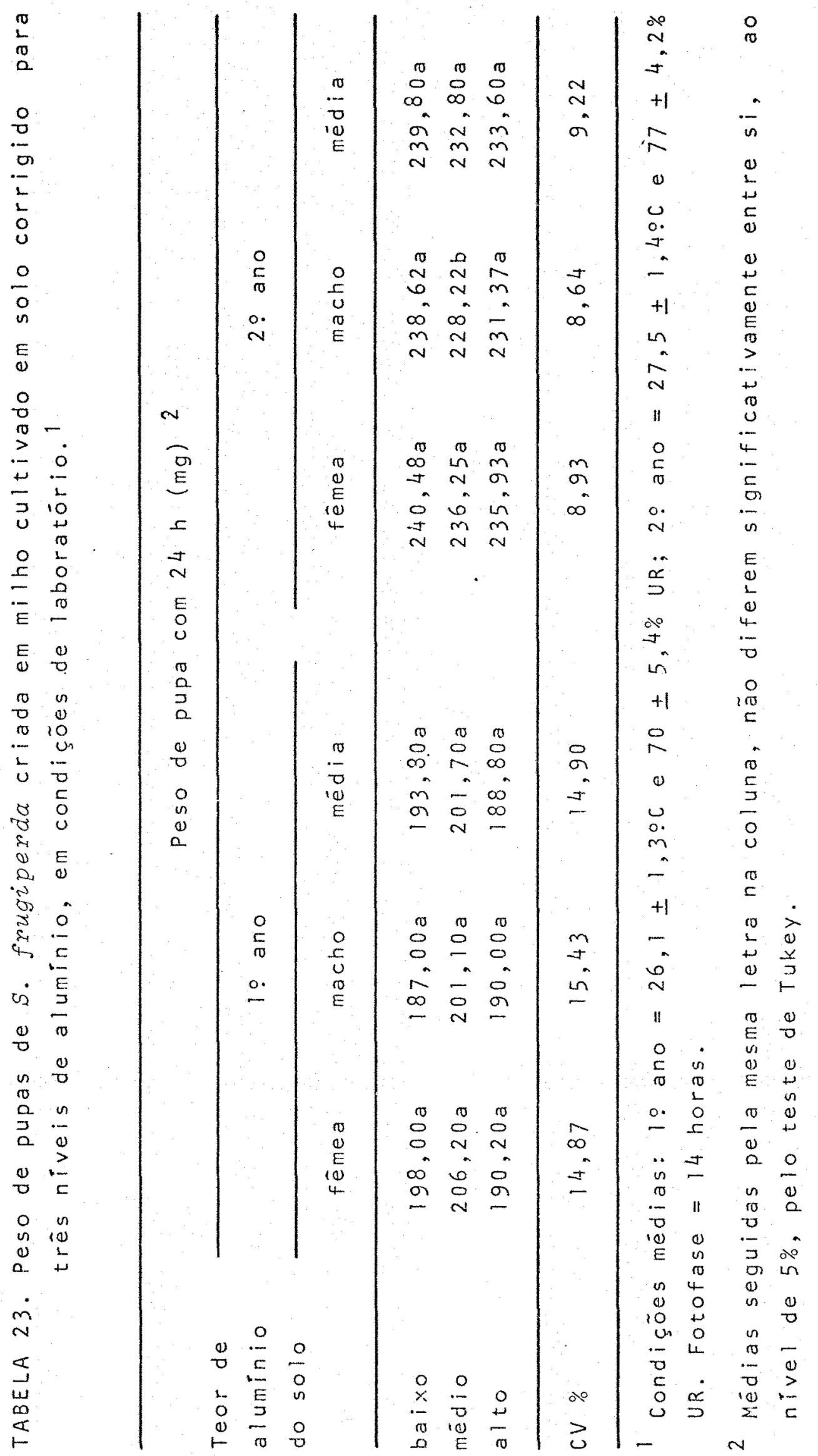




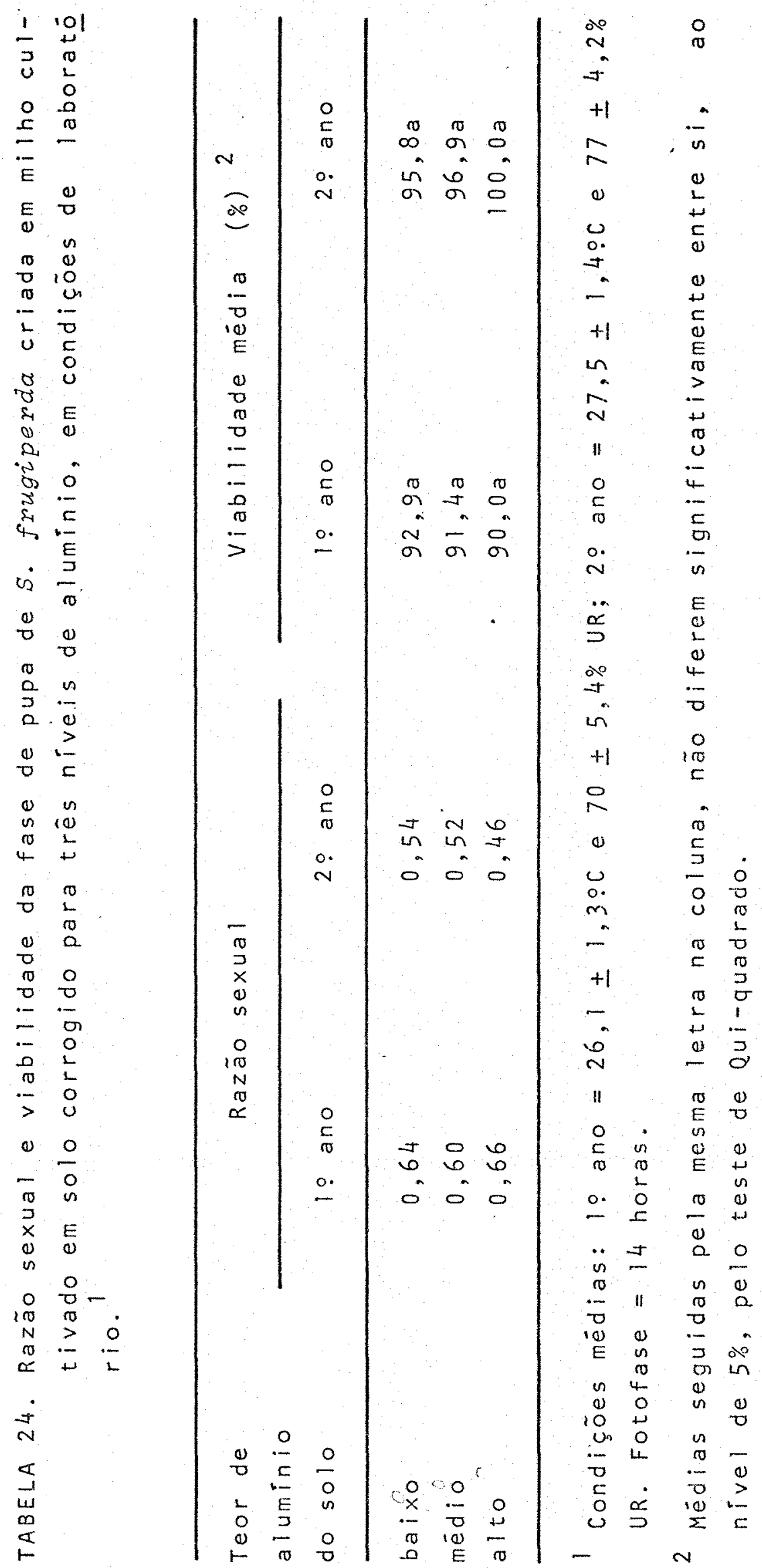




\subsubsection{Fase de adulto}

Não houve influência do teor de alumínio do solo na longevidade de adultos não alimentados no primeiro ano de estudo (Tabela 25). No segundo anó, quando fol observada a longevidade de adultos alimentados e não alimentados, constatou-se que embora o teor de alumínio do solo não tivesse influência sobre os primeiros, os adul tos não alimentados viveram mais tempo no solo com baixo teor de alumínio em relação aos demais. o efeito do teor de aluminio do solo foi diferente para os dois sexos (Tabela 26).

Somente os adultos não alimentados seguiram o modelo de distribuição de Weibull (Figura 1) e segundo este modelo, a longevidade média da população foi 4,$11 ; 3,66$ e 3,62 dias nos solos com teor de alumínio ba xo, médio e alto, respectivamente. A curva de sobrevivencia diária dos adultos alimentados mostrou que a tendência foi semelhante em todos os tratamentos (Figura 2).

A porcentagem de adultos portadores de al gum tipo de anormalidade não foi afetada pelo teor de alu mínio do solo (Tabela 27).

A reprodução só foi estudada no segundo $\underline{a}$ no e observou-se que não houve nenhum efeito do alumínio nos períodos de pré-oviposição, oviposição e pós-oviposição (Tabela 28). o nümero de dias de postura por fémea variou de 5 a 6 dias e o nümerototal de ovos por fêmea foi de 1678 em média, não havendo influência do teor de aluminio do solo sobre esses parâmetros (Tabela 29). 
83.

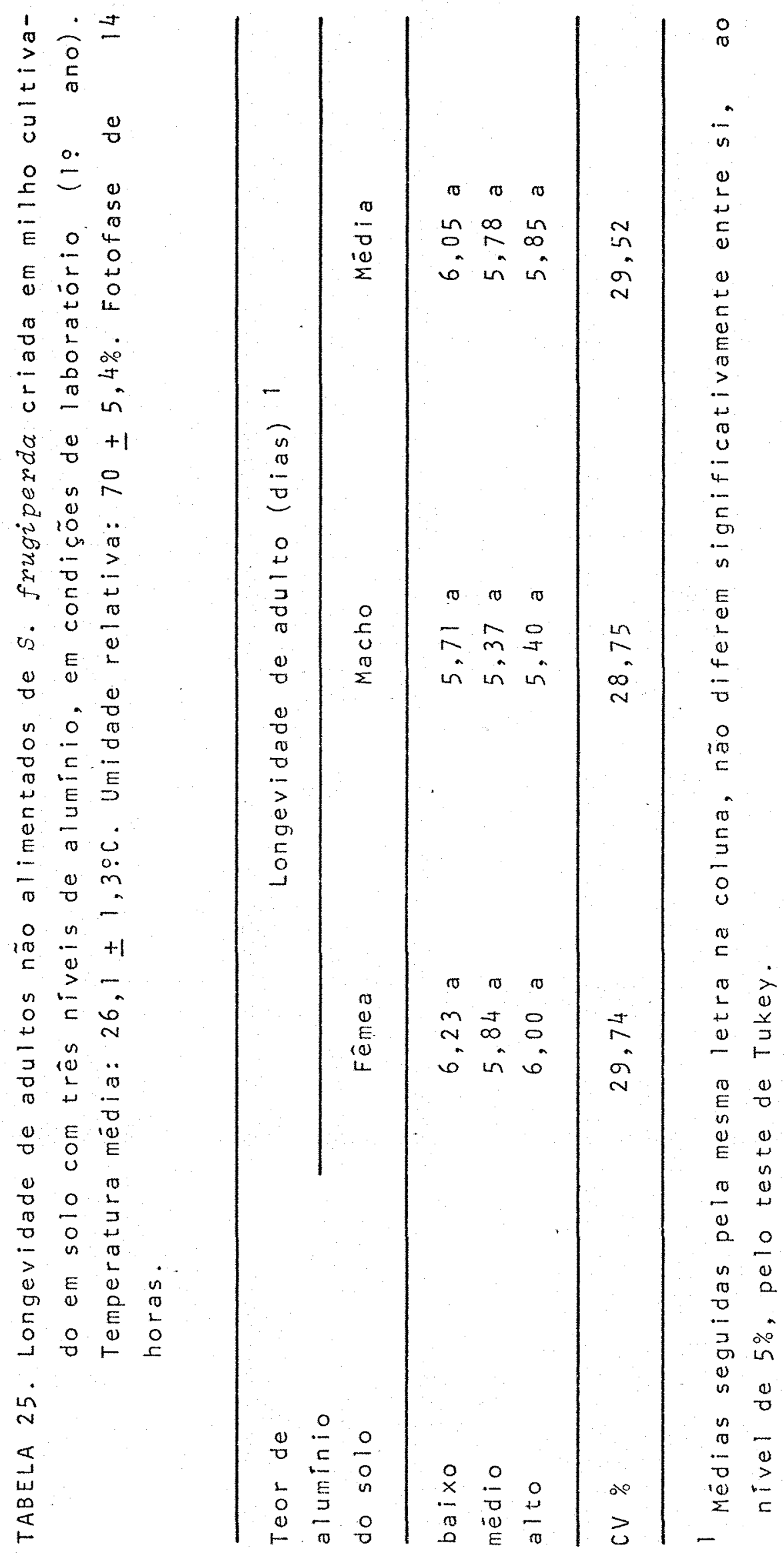


84.

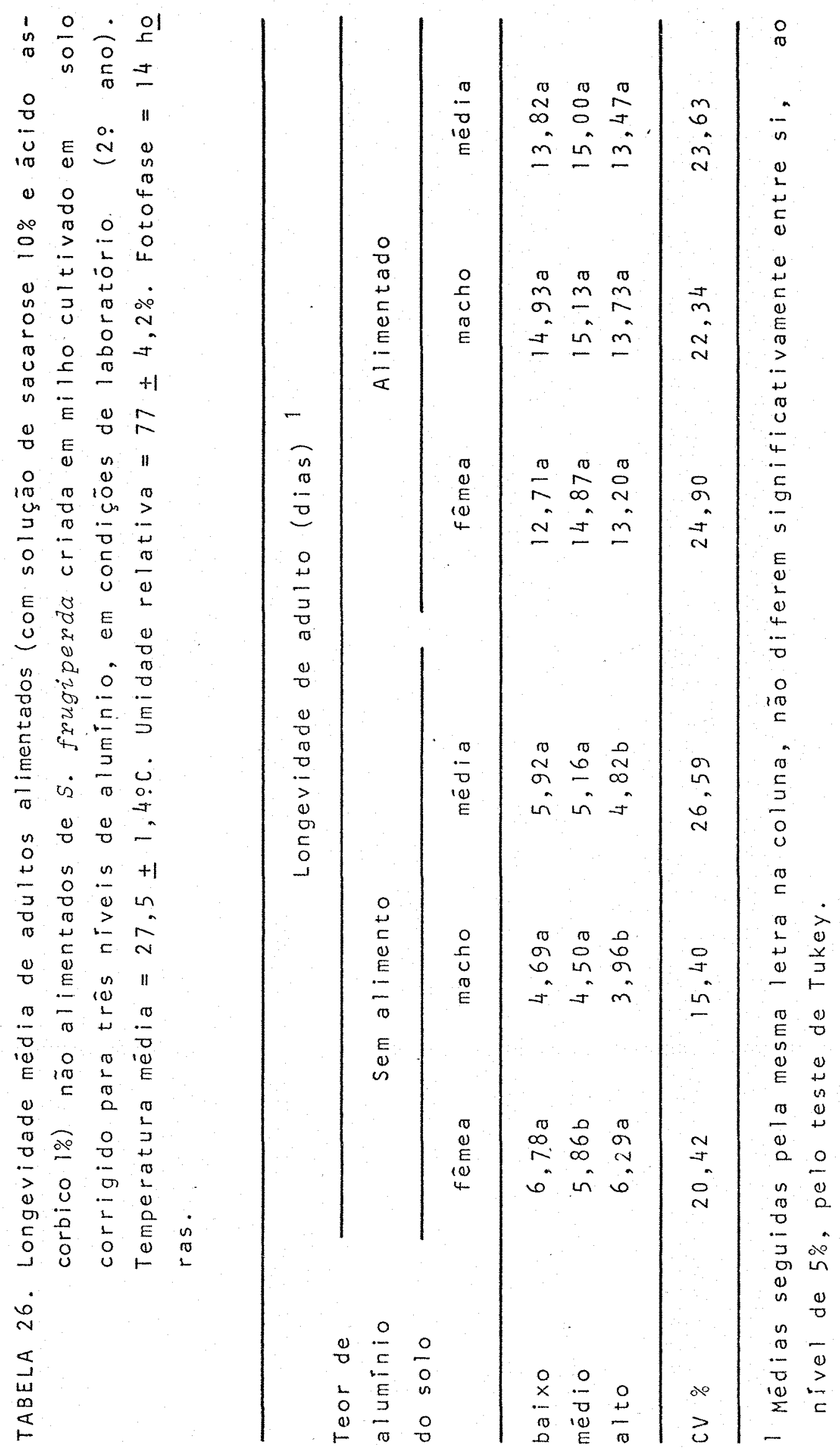


85.

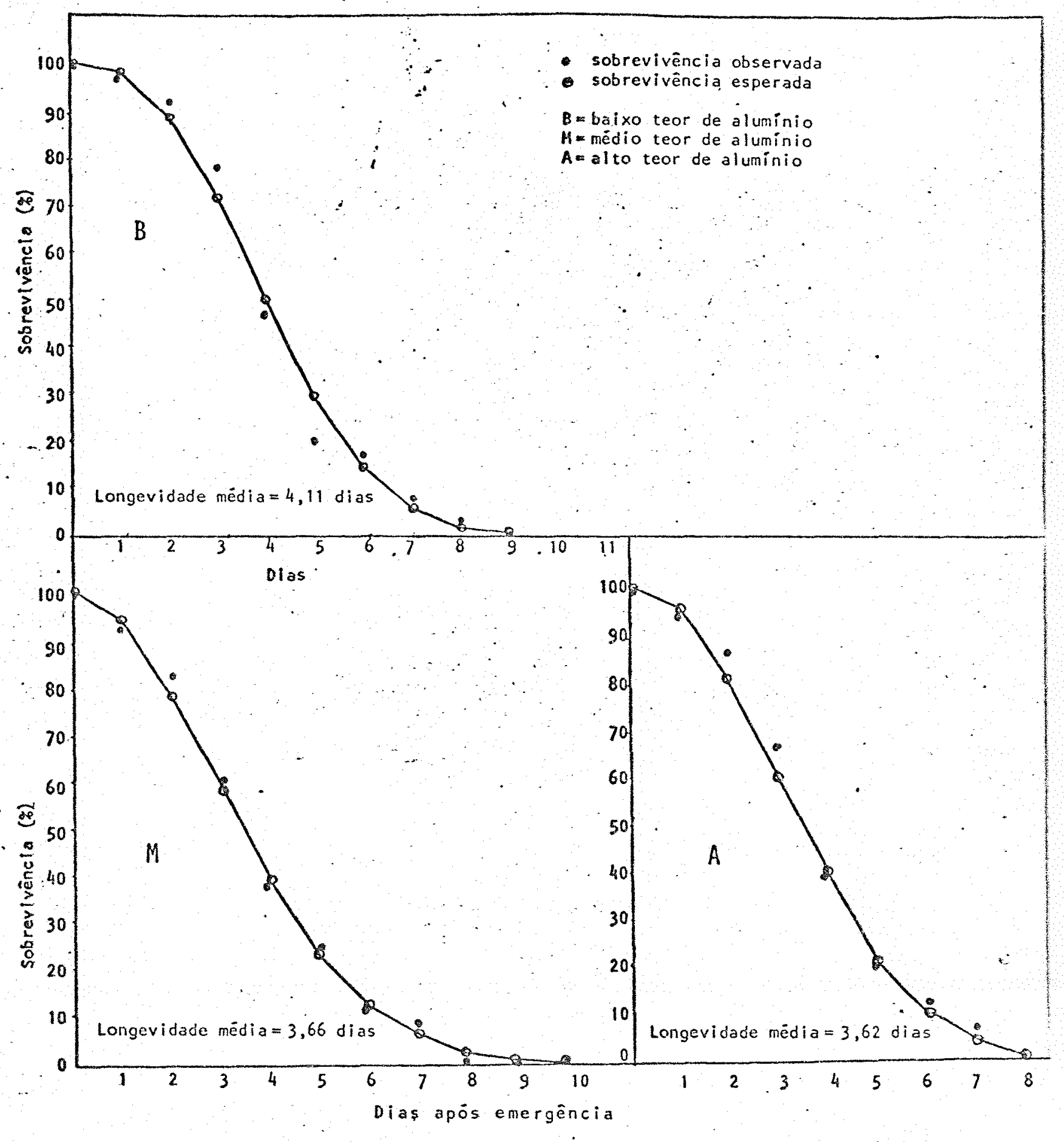

FIGURA 1. Curva de sobrevivência e de longevidade média de adultos de $S$. frugiperda não alimentados, segundo o modelo de distribuição de Weibull. 
86.

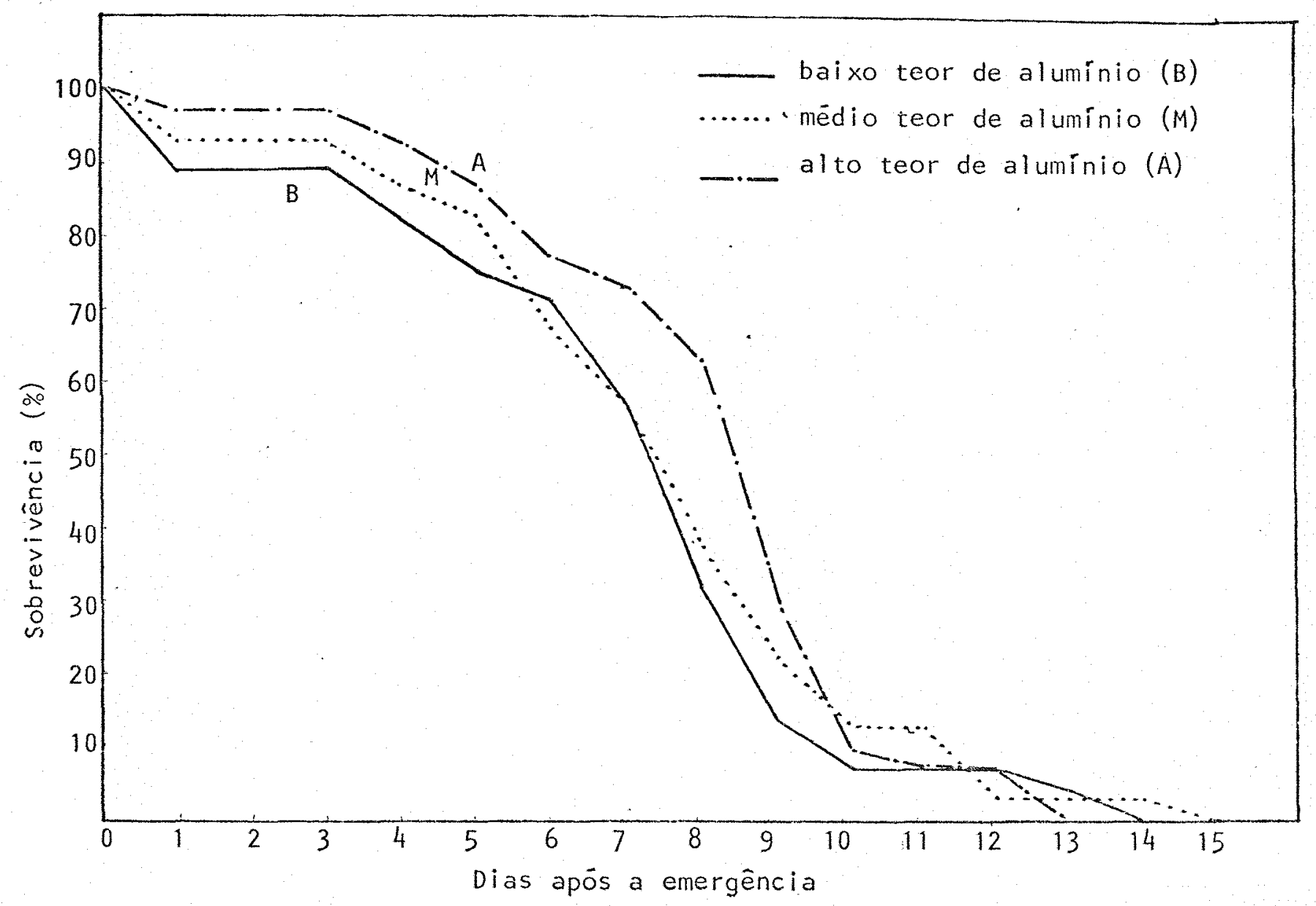

FIgURA 2. Curva de sobrevivencia de adultos de $S$. frugiperda al imentados com solução de sacarose $10 \%$ e ácido ascórbico 


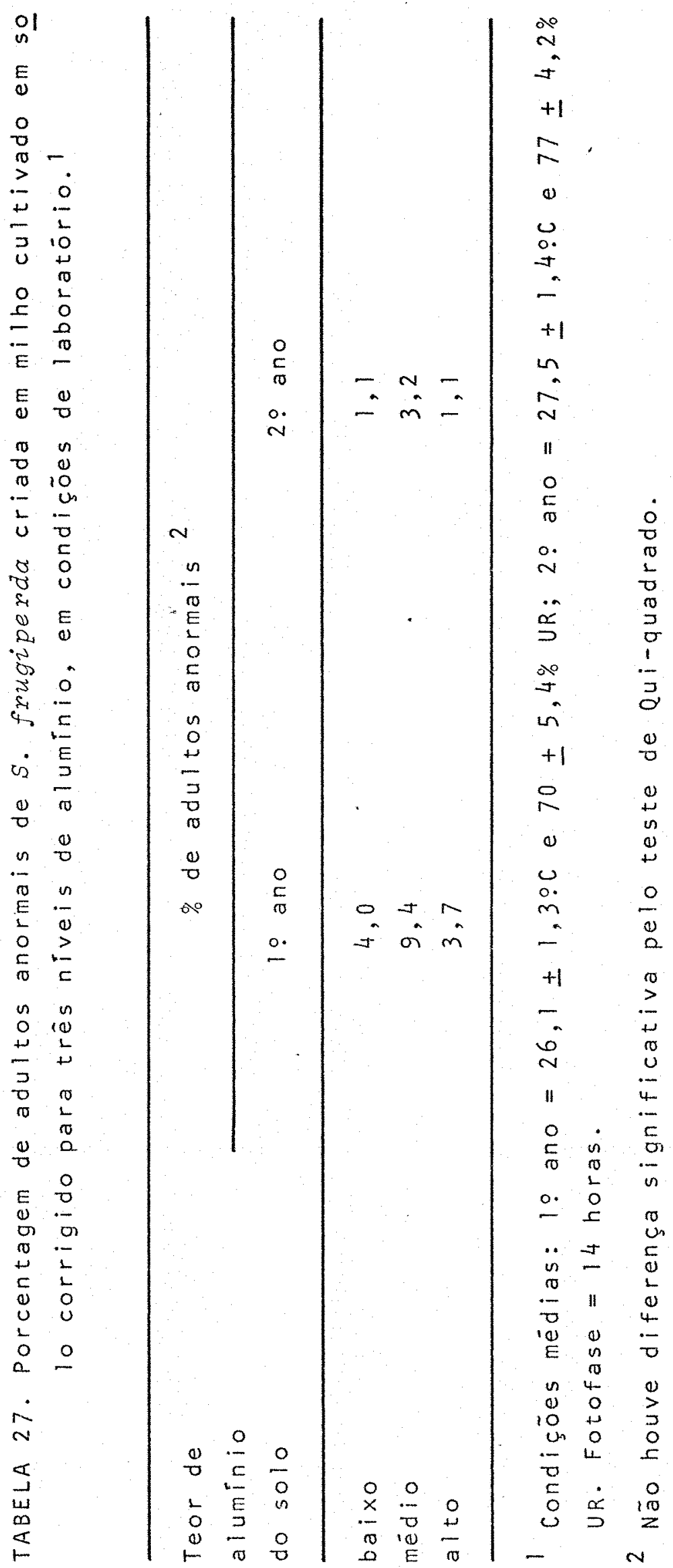




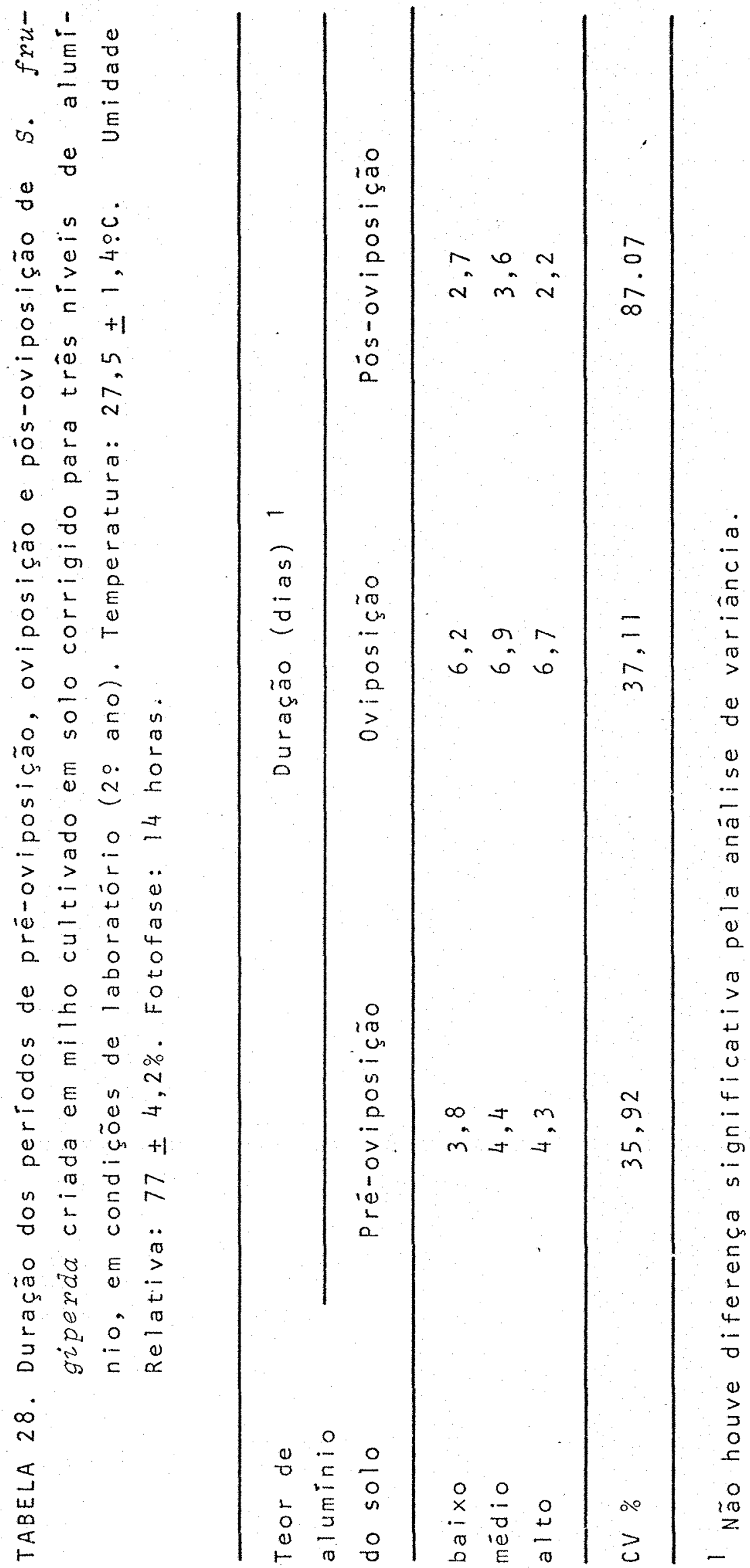




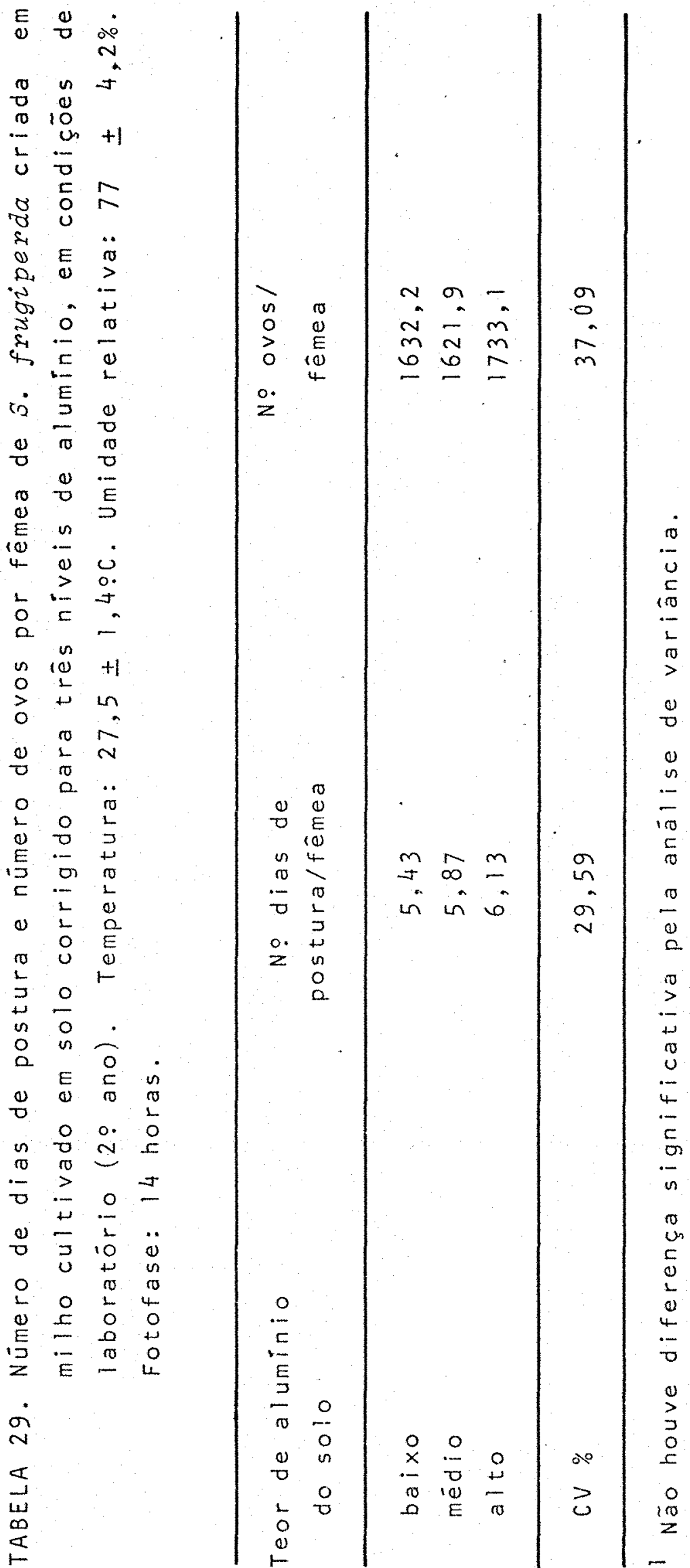


o comportamento das fêmeas em relação à oviposição diäria foi semelhante nos três níveis de alumí nio. Assim, para os três casos, entre oquinto e sētimo dias após a emergência, a postura e a viabilidade começaram a decrescer de forma marcante (Figura 3 ).

\subsubsection{Ciclo ovo-adulto}

o ciclo ovo-adulto, no primeiro ano, durou em mëdia 26,94 a 27,56 dias para fêmeas e 28,12 a 28,87 dias para machos, não sofrendo nenhum efeito do teor de aluminio do solo. No segundo ano a duração do ciclo das fêmeas $(27,35$ a 27,62 dias) não foil afetado, mas para os machos o ciclo ovo-adulto foi mais curto $(27,93 \mathrm{dis})$ no solo com teor de aluminio mëdio em relação ao alto $(28,62$ dias) embora não tenha diferido significativamente do ba xo teor de alumínio $(28,33$ dias $)$. Em termos médios, os teores baixo e médio de alumínio reduziram a duração do periodo ovo-adulto (Tabela 30$)$.

\subsubsection{Tabela de vida de fertilidade}

Pela tabela de vida de fertilidade observa-se que a taxa líquida de reprodução (Ro), a capacidade de aumentar em nūmero $(r m)$ e a razão finita de aumento ( $\lambda$ ) decresceram do menor para o maior nivel de alumínio, sendo o intervalo de variação maior no solo com mais aluminio, onde inclusive o tempo de duração média de uma geraf̧ão (T) foi maior (Tabela 31 ). 


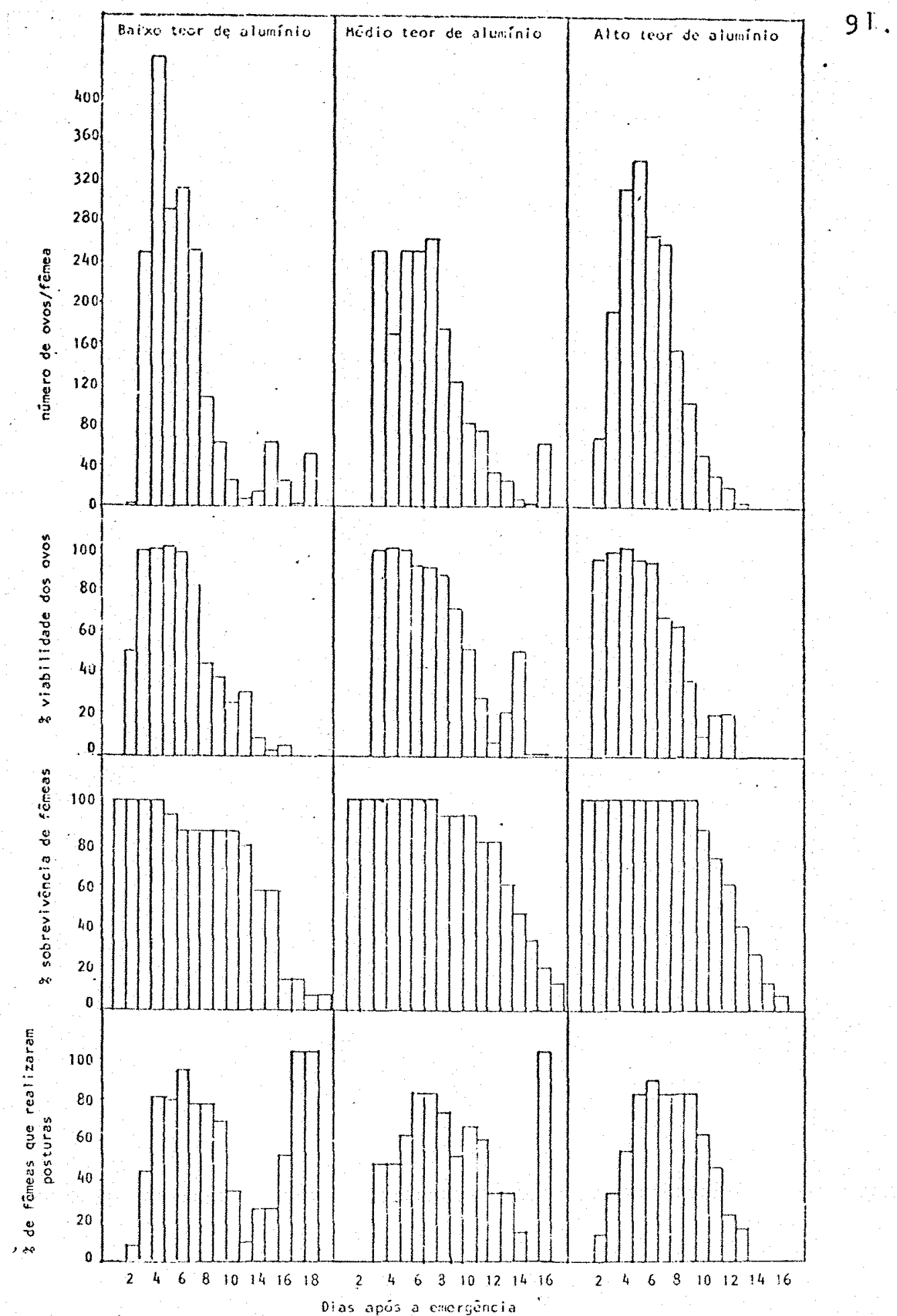

FIGURA 3. Número e viabilidade de ovos por fêmea, sobrevivência e porcentagem de fêmeas que realizaram posturas de uma população inicial de quinze fêmeas por tratamento. 


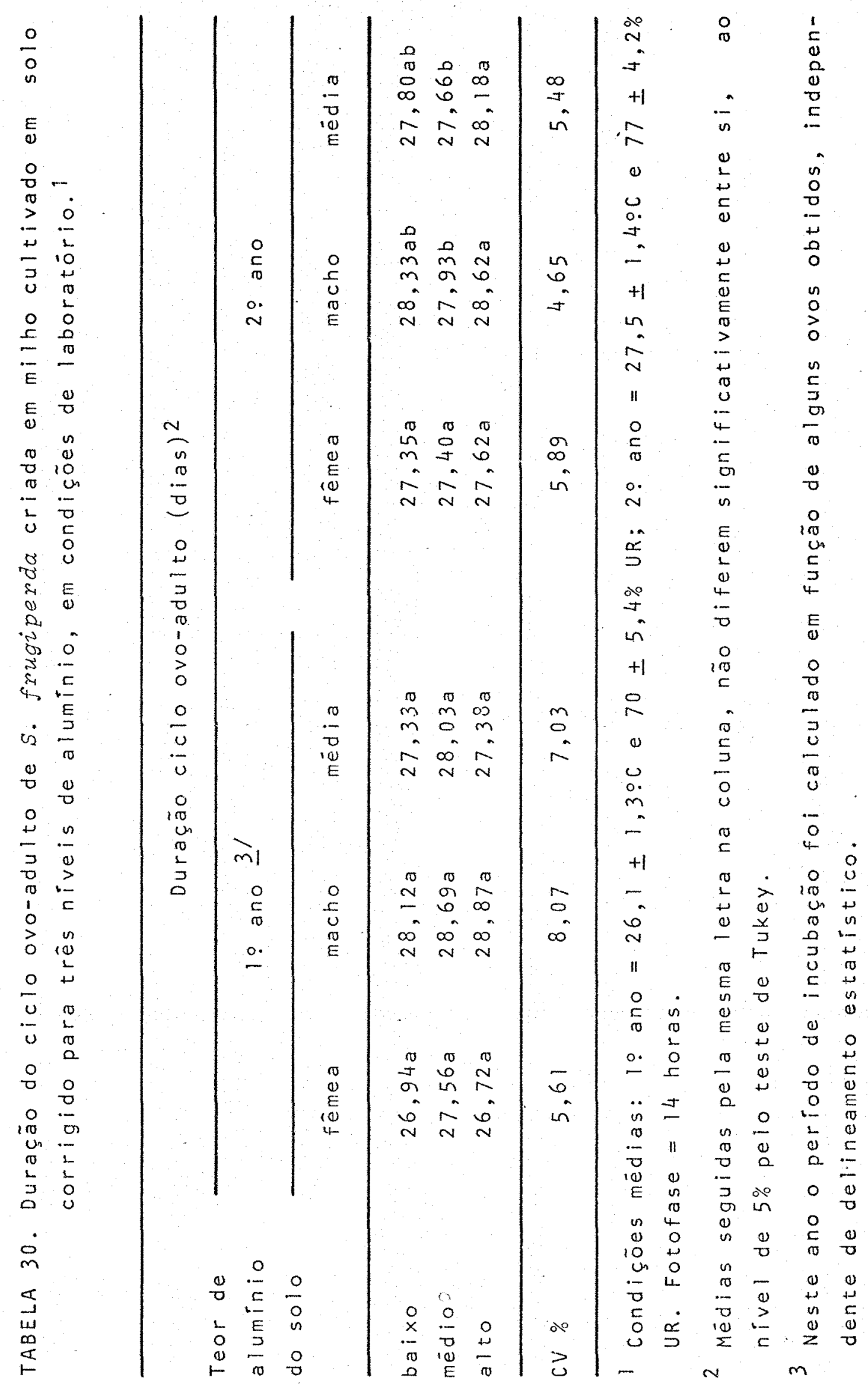




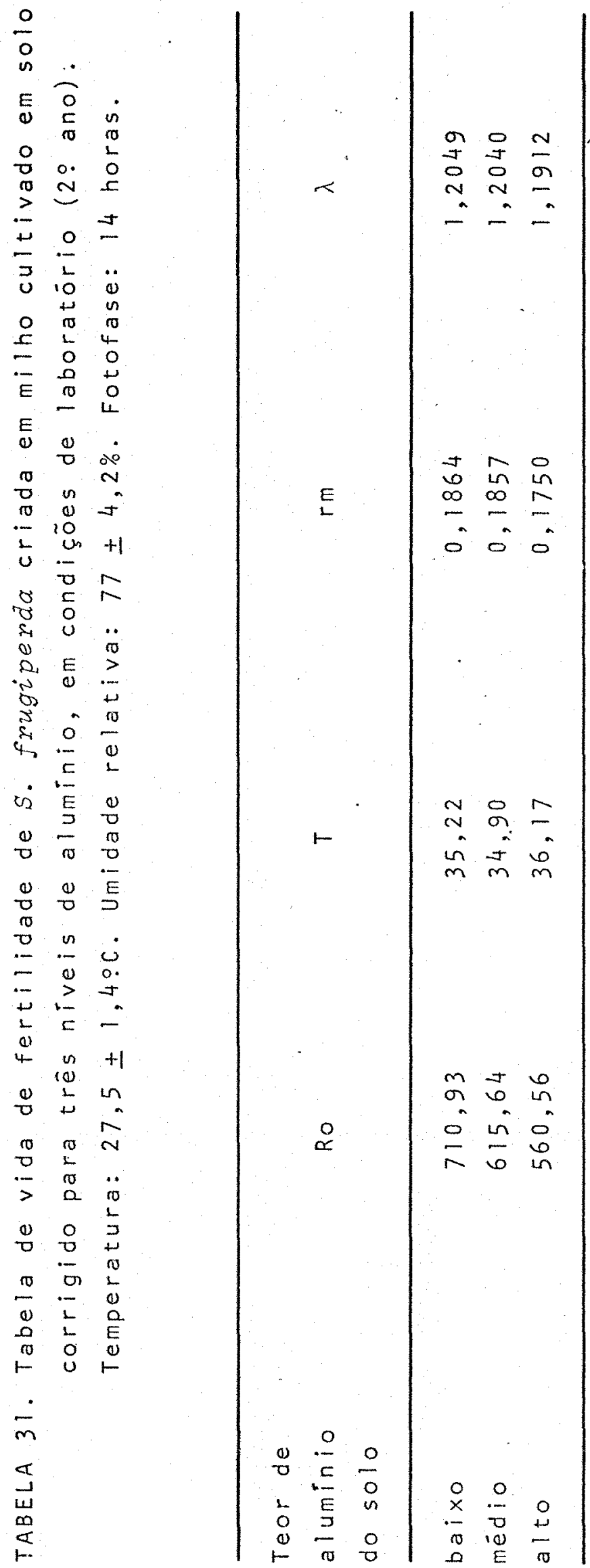


Esses resultados evidenciam que as fol has de milho produzidas no solo com alto teor de aluminio são menos adequadas ao inseto que aquelas produzidas nos solos com médio e baixo teor de aluminio.

\subsubsection{Considerações gerais sobre o efeito do teor de aluminio do solo no desenvolvimento do inseto}

De maneira geral o teor de alumínio do so lo exerceu influência sobre a biologia de $S$. frugiperda, principalmente no segundo ano de estudo. Embora não se tenha obtido um gradiente que permita afirmar que quanto menor o teor de alumínio do solo melhor o desenvolvimento do inseto, pode-se notar que no geral as folhas provenien tes do solo com menor teor de aluminio favoreceram o inseto. Esse efeito pode ser melhor visualizado pela tabela de vida, que mostrou que as folhas de milho procedentes do solo com alto teor de alumínio foram menos adequadas que aquelas de solos com médio e baixo teor que não apresenta ram grandes diferenças entre si, embora no solo com baixo teor de aluminio, as folhas se mostrassem mais adequadas.

Como esse estudo foi conduzido apenas por uma geração, sugerem-se estudos por gerações sucessivas de S. frugiperda, no sentido de se avaliar o efeito dos teores de aluminio na descendéncia deste inseto. 


\subsubsection{NUTRIÇÃO QUANTITATIVA}

\subsubsection{Al imento ingerido}

Quando o alimento ingerido foi medido em função da àrea das folhas, não se observou a influência do teor de alumínio do solo em nenhum dos anos de estudo. Po rēm, quando a quantidade de alimento ingerido foi avaliado em termos de mg de matéria seca, observou-se que no primeiro ano o consumo foi afetado pelo alumínio do solo, sendo menor no baixo teor de aluminio em relação ao médio, não havendo, entretanto, diferença significativa quan to ao solo com alto teor de aluminio (Tabela 32 ). No segundo ano, novamente o consumo em função da matéria seca foi significativamente menor no solo com baixo teor de aluminio em relação aos demais, os quais não diferiram en tre si (Tabela 33).

\subsubsection{Al imento assimilado}

o alimento assimilado foi influenciado pe 10 aluminio do solo. Nos dois anos de estudo, o alimento utilizado para metabolismo e conversão em biomassa foi significativamente menor quando as folhas foram produzi das no solo com baixo teor de aluminio. Entre os solos com baixo e médio teor de alumínio não houve diferença significativa no primeiro ano, mas no segundo ano, a quantidade de alimento assimilado foi maior quando as folhas vie- 


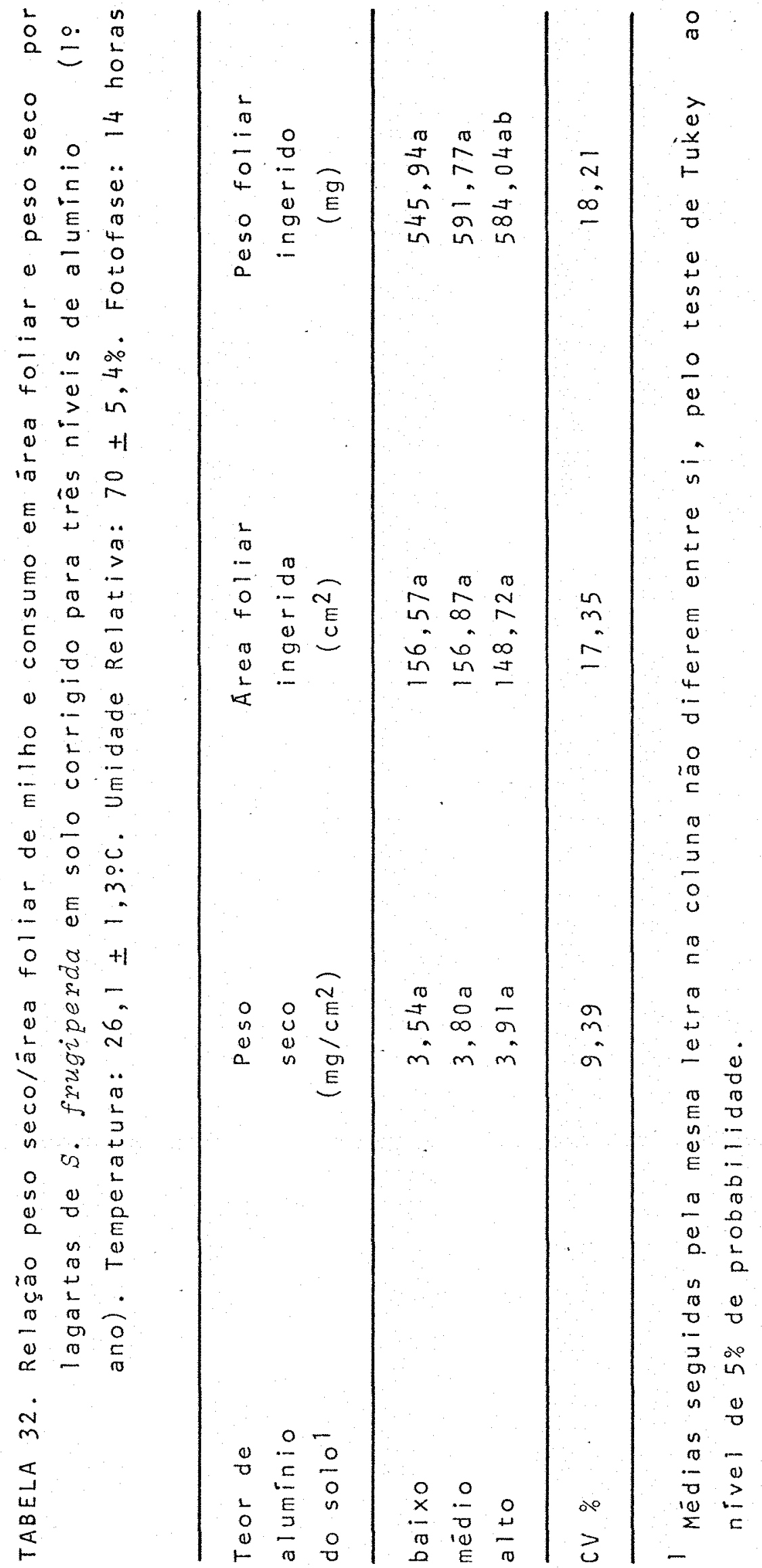




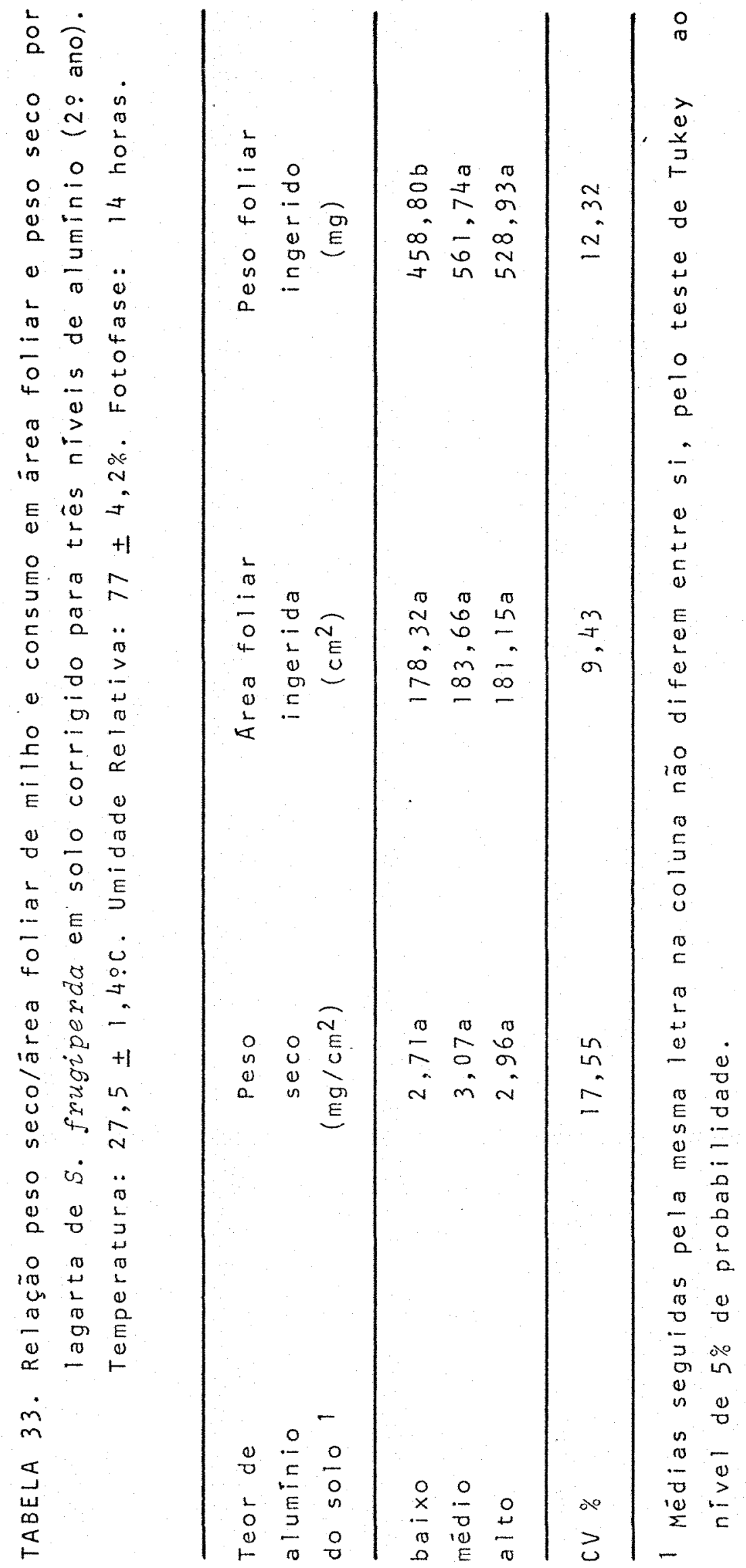


ram do solo com teor de alumínio médio, em relação às pro venientes de solo com teor de aluminio alto (Tabela 34).

\subsubsection{Alimento metabolizado (M)}

o alimento metabolizado, que segundo SCRI BER \& SLANSKY JR. (1981), representa a parte do alimento assimilado que foi utilizado na forma de energia para o metabolismo do inseto, foi afetado pelo teor de aluminio do solo, notadamente no segundo ano. A quantidade de alimento metabolizado foi sempre menor quando as folhas foram produzidas nos solos com baixo teor de aluminio (Tabe 1a 35).

\subsubsection{Ganho de biomassa (B)}

A biomassa ganha durante toda a fase larval foi semelhante em todos os niveis de alumínio do so10, nos dois anos de estudo, variando de 80,73 a $85,61 \mathrm{mg}$ de matèria seca (Tabela 36 ).

Esse fato sugere que as diferenças na quan tidade de alimento assimilado se devem ao gasto de ener gia no metabolismo e não à conversão em biomassa.

4.3.2.5. Tndices nutricionais

4.3.2.5.1. Taxa de consumo relativo (RCR)

Esse indice representa a quantidade do alimen to ingerido por unidade de peso corpóreo do inseto por dia. 
99.

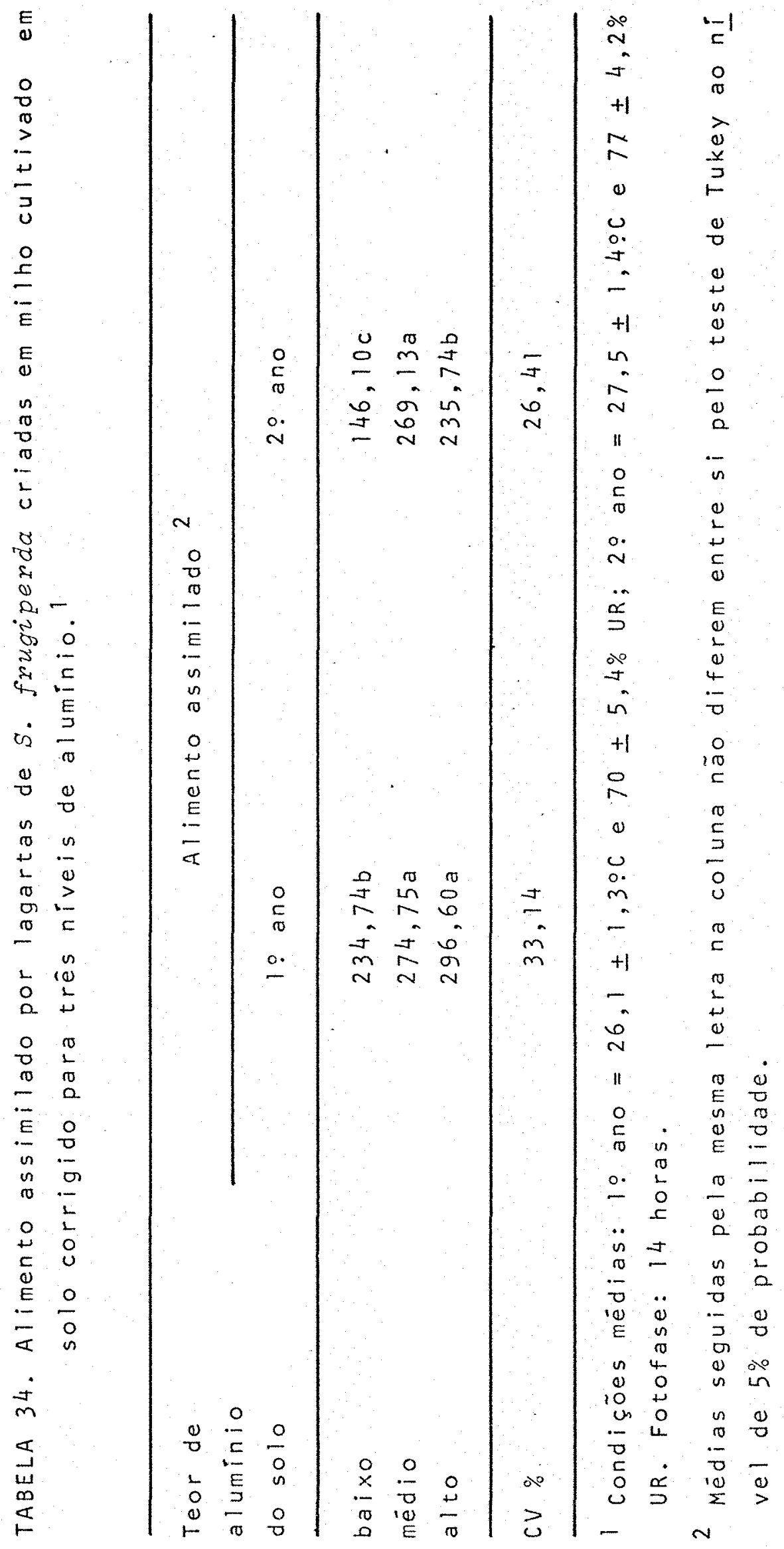


100.

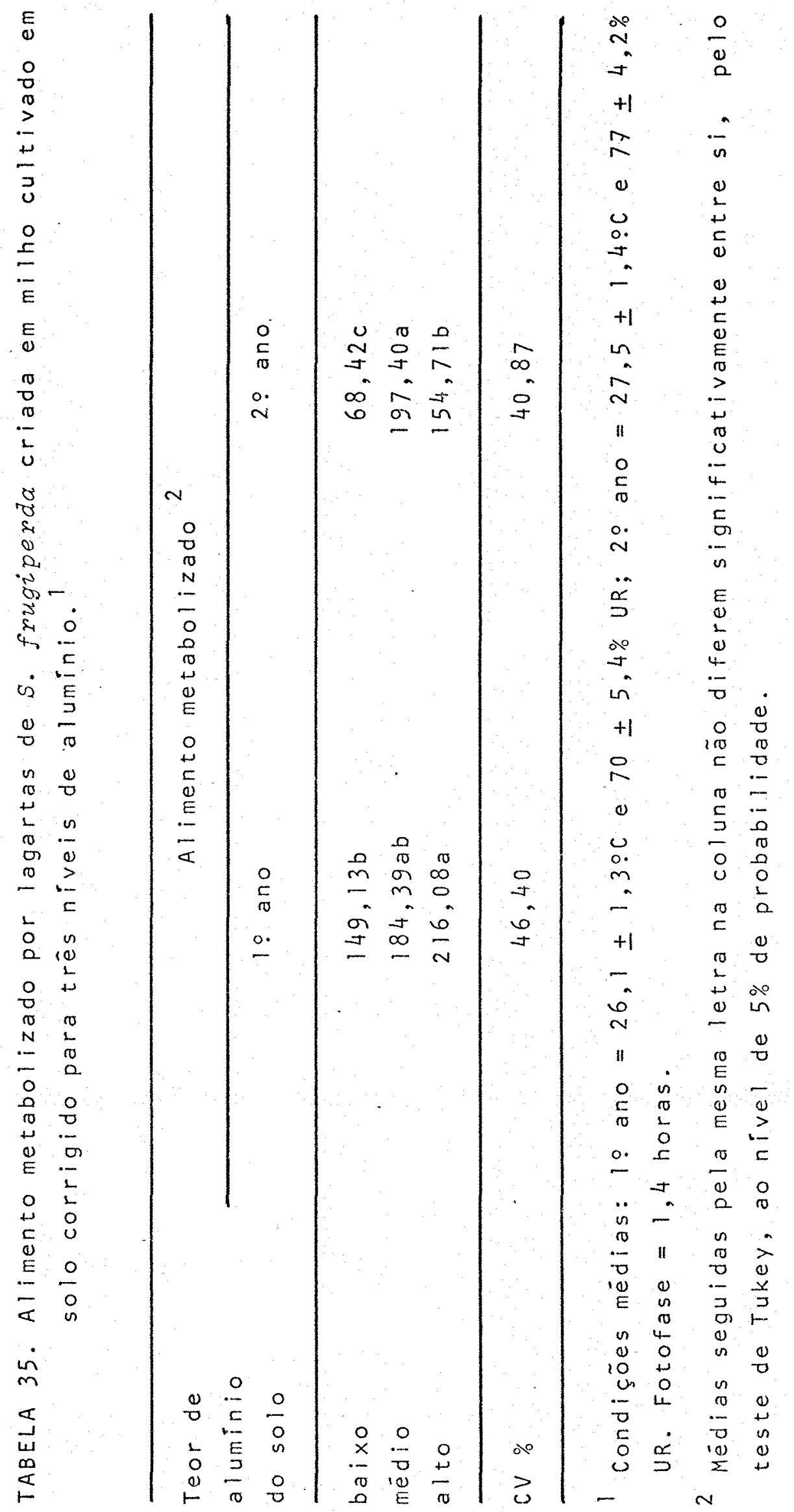


101.

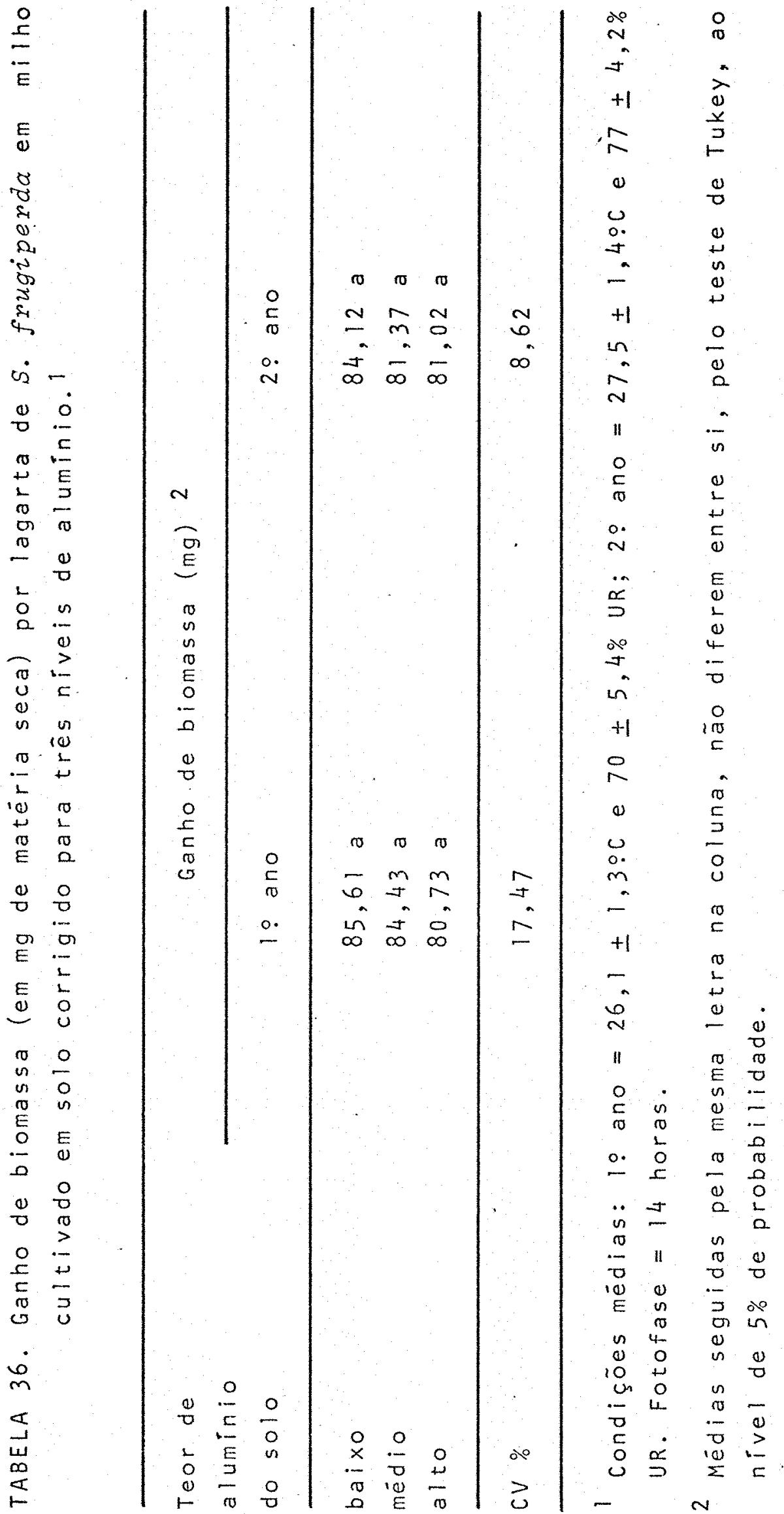


No primeiro ano, o valor de RCR foi signi ficativamente menor quanto mais baixo o teor de alumínio do solo (Tabela 37 ). No segundo ano, essa, taxa (RCR) tambëm foi menor no solo com baixo teor de alumínio (Tabela 38).

4.3.2.5.2. Taxa metabölica relativa (RMR)

A taxa metabölica relativa representa a quantidade de alimento gasto em metabolismo por unidadede biomassa do inseto por dia.

Essa taxa, no primeiro ano, foi maior quan do o teor de alumínio do solo era alto em relação aos outros, não havendo diferença significativa entre os solos com teores de aluminio médio e baixo (Tabela 37). No ano seguinte, o maior valor do RMR ocorreu no solo com médio teor e o menor no solo com baixo teor de aluminio (Tabela 38). Em termos gerais, foi maior nos solos com médio e al to teor de alumínio.

4.3.2.5.3. Taxa de crescimento relativo $(R G R)$

o ganho de biomassa pelo inseto em relação a seu peso (RGR) foi afetado pelo teor de alumínio do solo, sendo que, no primeiro ano, foi menor no solo com teor médio e no seguinte, o menor valor de RGR ocorreu no solo de alto teor de alumínio, não havendo diferença significativa entre os demais niveis de alumínio do solo (Ta belas 37 e 38 ). 
103.

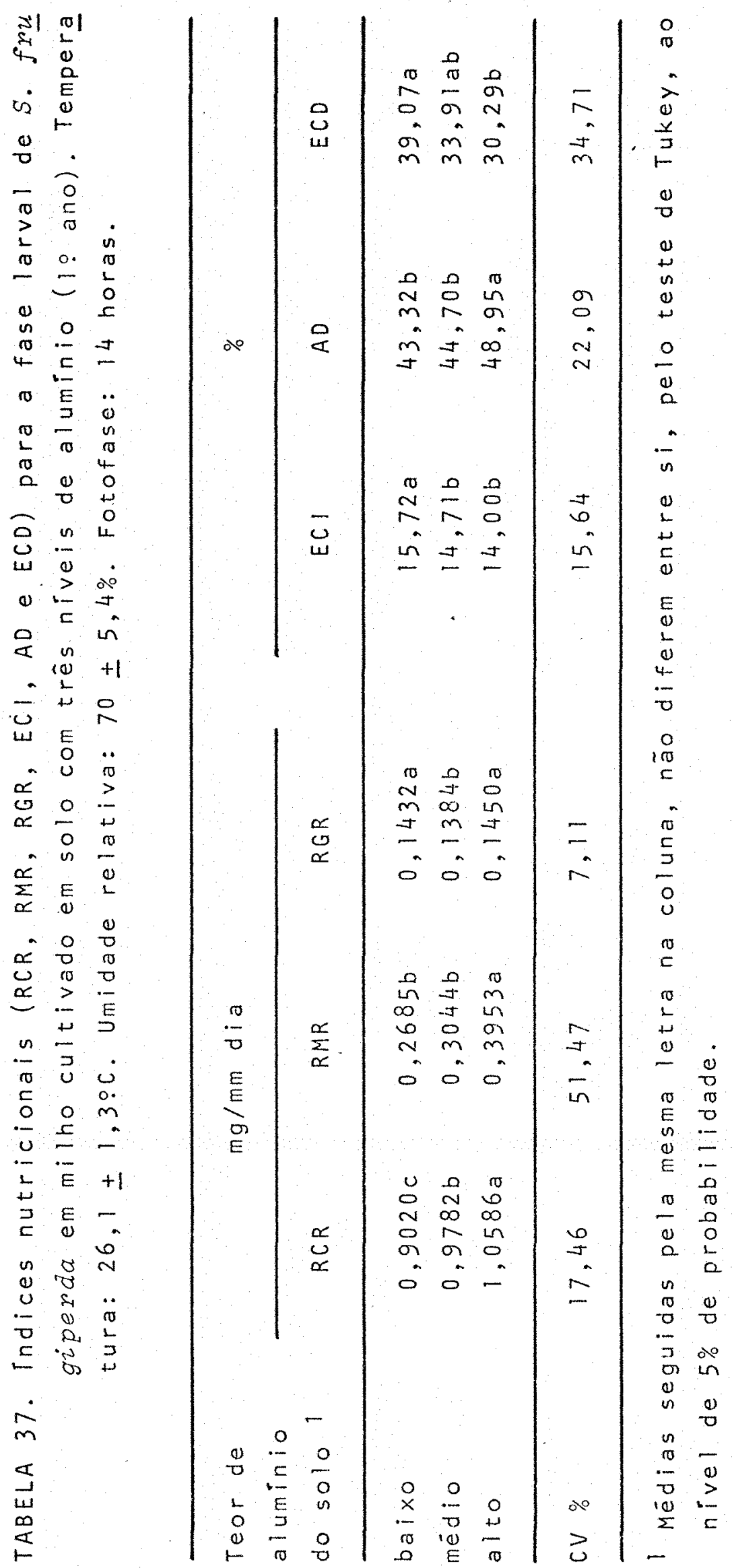


104.

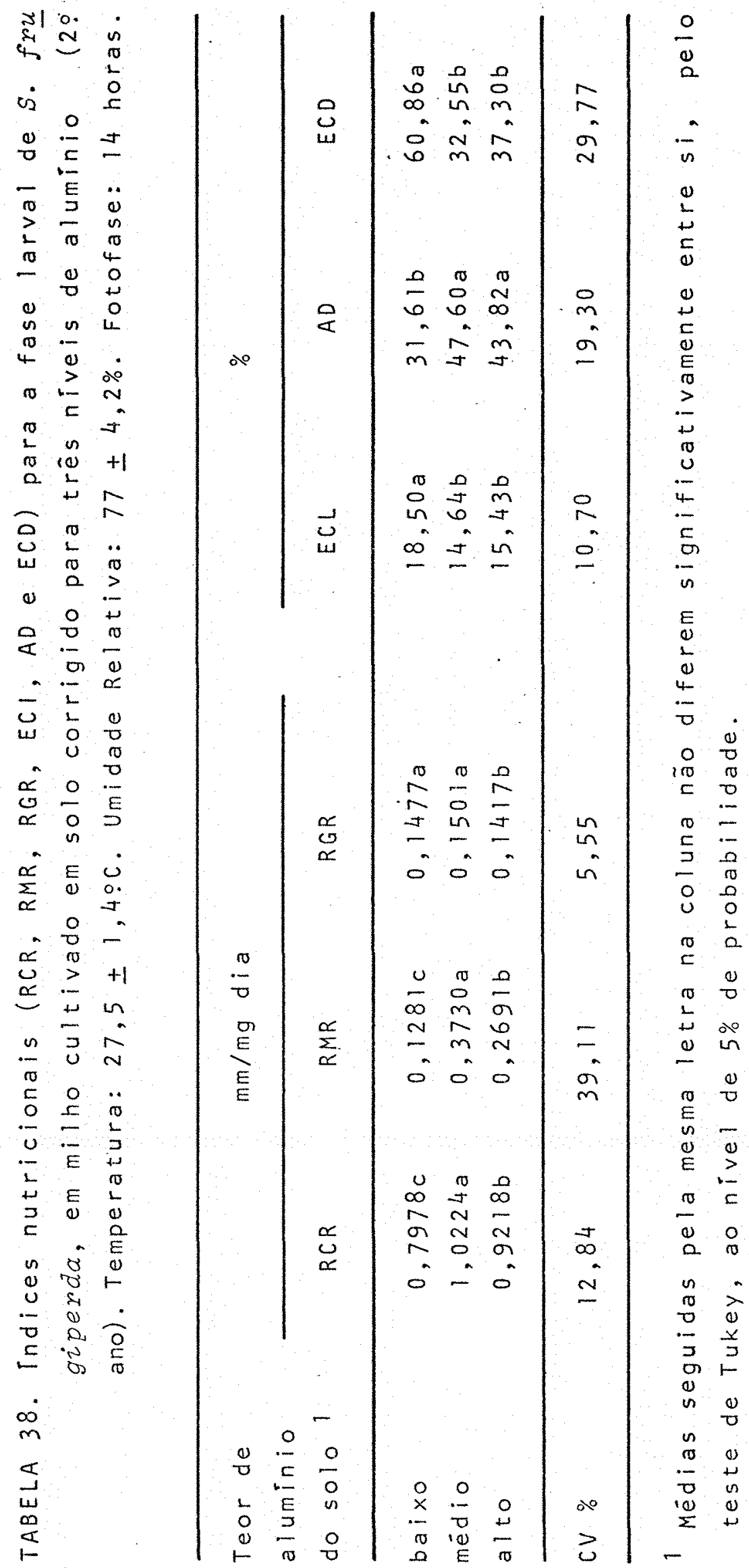


4.3.2.5.4. Eficiência de conversão do al $\underline{i}$ mento ingerido (ECI)

A ECI (porcentagem do alimento ingeridope 10 inseto, que é transformada en biomassal foi sempre maior no solo com baixo teor de alumínio em relação aos teores de alumínio médio e alto que apresentaram uma ECI semelhante (Tabelas 37 e 38 ).

4.3.2.5.5. Digestibilidade aproximada (AD)

A porcentagem do alimento ingerido efetivamente assimilado pelo inseto (AD) foi sempre menor no solo com baixo teor de alumínio (Tabelas 37 e 38 ).

4.3.2.5.6. Eficiência de conversão do al mento digerido (ECD)

No primeiro ano, só houve diferença signi ficativa na ECD (porcentagem do alimento diferido convertida em biomassa do inseto) entre os solos combaixo e al to teor de aluminio, sendo o valor de ECD maior no prime ro caso (Tabela 37 ). No segundo ano, novamente o valor de ECD foi maior no solo com baixo teor de alumínio, não havendo diferença significativa entre os solos com médio e alto teor de aluminio (Tabela 38 ).

$4 \cdot 3 \cdot 2 \cdot 5 \cdot 7$. Custo metabólico

A porcentagem do alimento metabolizado em energia (custo metabólico) para a manutenção da vida, foi sempre mais baixa no solo com baixo teor de alumínio, não havendo diferença significativa entre os outros dois ni- 
veis de aluminio do solo (Tabela 39), indicando ser o so10 com baixo teor de alumínio mais adequado ao inseto.

\author{
4.3.2.6. Considerações gerais sobre o \\ efeito do teor de aluminio do \\ solo na nutrição quantitativa do \\ inseto
}

A performance de crescimento das lagartas foi semelhante nas três situações estudadas, entretanto,o consumo e a eficiência de utilização do alimento foi diferente conforme o teor de aluminio do solo onde as foThas de milho foram produzidas.

As folhas de milho produzidas no solo com baixo teor de aluminio, podem ser consideradas como o all mento mais adequado, pois foram menos consumidas e melhor digeridas, apresentando ainda o menor custo metabólico. Pa ra as folhas produzidas nos solos com teor de aluminio mé dio e alto, a performance das lagartas foi semelhante e inferior àquele encontrado no solo com baixo teor de aluminio.

Uma análise geral dos resultados mostra que, seguindo o conceito de ecología nutricional proposto por SLANSKY \& SCRIBER (1985), houve uma resposta compensa tória, onde a lagarta mudou seu comportamento em relação a tomada de alimento procurando compensar as dificuldades na digestão e aproveitamento de alimento, variando a ingestão de folha sem alterar o desenvolvimento global, às custas, entretanto, de um maior gasto de energia no metabolismo. 
107.

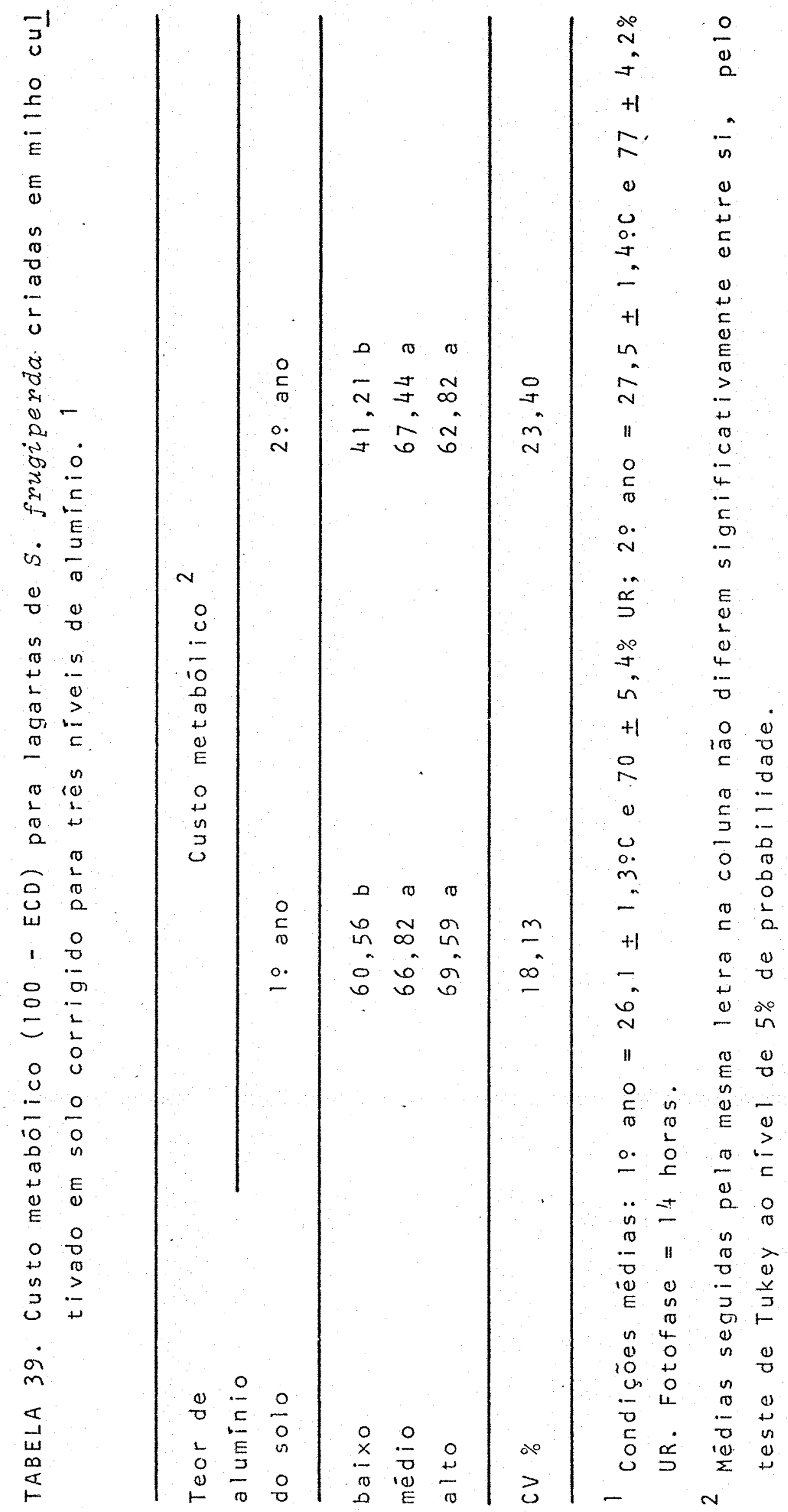




\subsection{Consideracĩ̃es Finais}

os resultados obtidos mostram que o teor de alumínio do solo onde o milho foi produzido, afeta tan to a biologia, como a nutrição de $S$. frugiperda.

As lagartas de $S$. frugiperda, de acordo com o que havia sido observado por CROCOMO \& PARRA (1985), apresentaram capacidade de compensar as dificuldades na utilização de alimento e manter até certo ponto, a perfor mance de desenvolvimento. No presente trabalho, embora o peso final das lagartas e pupas tenha sido semelhante, in dependentemente do teor de aluminio do solo onde as foIhas foram produzidas, a duração da fase larval foi menor, quando estas foram provenientes do solo com baixo teor de alumínio. Embora o ciclo ovo-adulto não tenha apre sentado grandes variações em função do teor de alumíniodo solo, uma fase larval mais curta e um menor tempo de ali mentação, possibilita um menor tempo de exposição do inseto aos inimigos naturais e outros fatores adversos.

Embora o desenvolvimento e sobrevivencia do inseto não tenham sido afetados de maneira marcante, a tabela de vida de fertilidade sugere que as gerações subsequentes podem ser afetadas. Assim, em estudos futuros seria interessante que fossem realizadas pesquisas por mais de uma geração.

Mesmo que o consumo de alimento, em termos de ärea foliar tenha sido semelhante em todos os níveis de aluminio do solo, as plantas no solo com alto teor 
de alumínio certamente foram mais injuriadas, uma vez que além do porte menor, tinham folhas nitidamente mais estreitas que as plantasno solo com baixo teor de alumínio, assim a relação entre a àrea foliar ingerida pelo inseto e a área total da planta foi maior no solo com alto teor de alumínio. Entretanto, nesse nivel de alumínio do solo, o inseto não afetou a produção final, sugerindo que neste caso a fertilidade do solo foi o fator dominante.

Nos outros dois niveis de alumínio do so10 o inseto afetou negativamente a produção no segundo ano, mas no ano mais seco, isso só ocorreu no solo com teor de alumínio baixo, não sendo o efeito do inseto detectado nos solos com teor de alumínto mëdio e alto.

Do ponto de vista agronômico considera -se que o solo bom baixoteor de alumi nio (e alto teor de cálcio + magnésio), é mais adequa do para a produção do mi tho. No entanto, não se deve desprezar - fato de que o inseto também é favorecido e que portanto devem ser feitos estudos mais prolongados do efeito do teor de alumínio do solo na sua dinâmica populacional. De qualquer maneira, embora a perda de produção das plantas infestadas por $S$. frugiperda em relação às não infestadas produzidas no solo com baixo teor de aluminio seja igual ou maior que a perda de produção relativa das plantas pro venientes do solo com teor de alumínio alto, em termos ab solutos a produção de grãos sempre fol maior no solo com baixo teor de alumínio. Esses resultados sugerem que o controle de S. frugiperda em milho sö seria economica mente compensador no solo com baixo teor de alumínio, apoi- 
ando as considerações de CHIANG (1978) de que o manejo de pragas deve ser feito dentro do manejo da cultura como um todo. Em função dos resultados obtidos compensa controlar $S$. frugiperda, apenas quando o solo de cerrado tiver - alumínio suficientemente corrigido, desde que nestas condições a praga causou reduções de $42,25 \%$ e $9,05 \%$ no pri meiro (ano mais seco) e segundo anos respectivamente, enquanto que nos solos com altos teores de aluminio a influência da praga não foi constatada. 


\section{CONCLUSÕES}

os resultados obtidos no presente trabaTho, permitem concluir:

a) o teor de aluminio e cälcio t magnésio do solo onde o milho foi produzido afeta a biologia e a nutrição quantitativa de $S$. frugiperda.

b) As folhas de milho produzidas no solo combaixo teor de aluminio e alto teor de cálcio + magnésio, são as mais adequadas para o inseto.

c) o quarto instar larval é o mais sensivel às variações no teor de elementos minerais (A), Ca e $\mathrm{Mg})$ do solo, podendo ser utilizado como padrão neste tipo de estudo.

d) Os parâmetros nutricionais são mais ade quados para analisar a influência do teor de alumínio e cálcio + magnésio do solo sobre S. frugiperda em relação aos parâmetros biológicos.

e) A tabela de vida de fertilidade é, den tre os parâmetros biológicos estudados, o mais adequado para este tipo de estudo. 
112.

f) Deve-se realizar o controle de $S$. frugiperda em solos de cerrado apenas quando o teor de aluminio não for alto. 


\section{REFERENNCIAS BIBLIOGRAFICAS}

AL-ZUBAIDI, F.S. \& CAPINEIRA, J.L. Application of different nitrogen levels to the host $\dot{p}$ lant and cannibalistic behavior of Beet Armyworm, Spodoptera exigua (Hubner) (Lepidoptera: Noctuidae). Environ. Entomol., College Park, $12(6): 1687-9,1983$.

ARCHER;T.L.; ONKEN, A.B.; MATHESON, R.L. \& BYNUM JR., E.D. Nitrogen fertilizer influence on Greenbug (Homoptera: Aphididae) dy namics and damage to sorghum. J. Econ. Entomol.. College Park, $\underline{75}(4): 695-98,1982$.

AUERBACH, M.J. ESTRONG, D.R. Nutritional ecology of HeZiconiaherbivores: experiments with plant fertilization and alternate hosts. Ecol. Monogr. Djarham, 51: 63-83, 1983 .

BAKER, J.S. E TAUBER, 0.E. Fecundity of the pea aphid on garden under various combinations of light, moisture and nutrients. J.Econ. Entomol.. College Park, 47: 113-117, 1954 .

BERTELS, A. \& ROCHA, M.A.B. Observaçōes preliminares sobre pragas do milho. Agros. Pelotas, $3(3): 160-33,1950$. 
BHAT, N.S. E BHATTACHARYA, A.K. Consumption and utilization of soybean by Spodoptera litura (Fabricius) at different temperatures. Indian J. Ent.. New Delhi, 40 (1): 16-25, 1978.

BOWLING, C.C. Rearing of two lepidopterous pests of rice on a common artificial diet. Ann. Entomol. Soc. Amer. College Park, 60 $(6): 1215-6,1967$.

BREWER, J.W.; CAPINERA, J.L.; DESHON Jr., R.E. \& WASMSLEY, M. L. Influence of foliar nitrogen levels on survival, deve lopment and reproduction of Western spruce Budworm, Choms toneura occidentalis (Lepidoptera: Tortricidae). Can.Entomol.. ottawa, 117:23-32, 1985 .

BURTON, R.L. E PERKINS, W.D. WSB, a new laboratory diet for the corn earworm and the fall armyworm. J.Econ. Entomol.. Baltimore, $65(2): 385-6,1972$.

BUTT, B.A. E CANTU, E. Sex determination of lepidopterous pupae. ARS, U.S.D.A., Washington, ne. 33-75, 1962. $7 p$.

CARVALHO, R.B.; TRISTÃO, M.M.; GIACON, E.; CALAFIORI, M.H.; TEIXEIRA, N.T. E BUENO, B.F. Estudo de diferentes dosagens de potássio em milho (Zea mays L.) influindo sobre spodoptera frugiperda (j.E. Smith, 1797). Ecossistema.Pinhal, 9: $95-100,1984$.

CARVALHO, R.P.L. Danos, flutuação de população, controle e comportamento de Spodoptera frugiperda (J.E. Smith, 1797) susceptibilidade de diferentes genótipos de milho em condiçóes de campo. Piracicaba, 1970. 170p. (DoutoradoEscola Superior de Agricultura "Luiz de Queiroz"/USP).

CICERO, S.M. Efeitos da fertilidade do solo sobre a produção e a qualidade das sementes de milho (zea mays L.). Piracicaba, 1979. 85p. (Doutorado - Escola Superior de Agricultura "Luiz de Queiroz"/USP). 
CHIANG, H.C. Pest management in corn. Ann. Rev. Entomol. Palo Alto, 23: 101-23, 1978 .

CLAVIJO, S. Effects of nitrogen fertilization and different levels of infestation by Spodoptera frugiperda (Lepidoptera: Noctuidae) on the yields of maize. Rev. Fac. Agron.. Maracay, 13(1-4): 43-48, 1984.

COMISSÃO DE FERTILIDADE DE SOLOS DO ESTADO DE MINAS GERAIS. Recomendações para o uso de corretivos e fertilizantes em Minas Gerais, 3ạ aproximação. Belo Horizonte, EPAMIG, 1978.

CROCOMO, W.B. E PARRA, J.R.P. Biologia e nutrição de Eacles imperialis magnifica Walker, 1856 (Lepidoptera: Attacidae) em cafeeiro. Rev. Bras. Entomol. São Paulo, 23(2): 51-76, 1979.

CROCOMO, W.B. E PARRA, J.R.P. Consumo e utilização de milho, trigo e sorgo por Spodoptera frugiperda J.E.Smith, 1797) (Lepidoptera, Noctuidae). Rev. Bras. Entomol.. São Paulo, $\underline{29}(2): 225-60,1985$.

CRUz, I. Impact of Fall Armyworm, spodoptera frugiperaa (Smith and Abbot, 1797), on Grain Yield in Field Corn. West Lafayette, 1980.162p. (Master of Science Thesis - Furdue University).

CRUz, 1. Resistência de mi lho a lagarta do cartucho (Spodoptera frugiperia). Rel. Téc. Anu. CNPMS 1980-1984. Sete La goas, $3: 73-4,1986$.

CRUZ, I. E TURPIN, F.T. Efeito da Spodoptera frugiperda em diferentes estädios de crescimento da cultura do milho. Pesq. Agropec. Bras.. Brasilia, 17(3): 355-59, 1982 .

CRUZ, I.; SANTOS, J.P. E OLIVEIRA, A.C. Competição de inseticidas visando o controle químico de spodoptera frugiper da (J.E. Smith, 1797) em milho. An. Soc. Entomol. Brasil., Jaboticabal, 12(2): $235-42,1983$. 
116.

CRUZ, 1. E SANTOS, J.P. Diferentes bicos do tipo leque no controle da lagarta - do - cartucho em milho. Pesq. Agropec. Brasil. Brasilia, 19 (1): $1-7$, 1984.

DEW, J.A. Fall armyworm Laphygma frugiperda (S. E A.). J. Econ. Ent.. Baltimore, 6 (4): $361-6,1913$.

DYAR, H.G. The number of molts of lepidopterous larvae. Psyche. Massachussets, $5: 420-2,1890$.

EDWARDS, P.J. E WRATTEN, S.D. Ecology of Insect Plant Interations, London, Edward Arnold Publishers, 1980. $71 \mathrm{p}$.

EMBRAPA, Centro Nacional de Pesquisa de Milho e Sorgo. Recomendaçōes Técnicas para o cultivo do milho. Circular Técni ca. Sete Lagoas, $1.4,1982$. 49p.

ETCHEVERRY, M. Laphygma frugiperda (Abbot $\& S m i t h$ ) in Chile (Lepidoptera: Noctuidae). Rev. Chil. Ent.. Santiago, 5: $183-192,1957$.

EVANS, A.C. Physiological relationships between insects and their host plants. Ann. Appl. Biology. Cambridge, 25(3): $558-72,1938$.

FERRAZ, M.C.V.D. Determinação das exigências térmicas de Spodoptera frugiperda (J.E. Smith, 1797) (Lepidoptera: Noc tuidae) em cultura de milho. Piracicaba, 1982.8 81 p. (Mes trado - Escola Superior de Agricultura "Luiz de Queiroz"/ USP).

FoX, L.R. E MAGAULEY, B.J. Insect grazing on Eucalyptus in response to variation in Real tannis and nitrogen. oecolo gia. Berlin, 29: 145-62, 1977. 
GARCIA, L.R. \& HABIB, M.E.M. ocorrência do fungo entomógeno Aspergizzus parasiticus Speare em adultos de Spodoptera frugiperda (Abbot e Smith, 1797) (Lepidoptera: Noctuidae), mantidos em laboratörio. An. Soc. Entomol. Brasil.. Itabu na, $\underline{7}(1): 15-16,1978$.

GARNER, J.W. E LYNCH, R.E. Fall Armyworm Leaf Consumption and development on florunner peanuts. J.Econ. Entomol. Col lege Park, 74(2): 191-3, 1981 .

HARREWIJN, P. Reproduction of the aphid Myzus persicae related to the mineral nutrition of potato plants. Ent. exp. Eappl., Amsterdan, 13: 307-19, 1970.

ISHII, S. Nutritional studies of the rice stem borer Chilo suppressazlis (walker). In: The major insects pests of the rice plant. Baltimore, John Hopkins Press, 1967. p. $229-39$.

ISRAEL, P. Varietal resistance to rice stem borer in India. In: The major insects pests of the rice plant. Baltimore. John Hopkins Press, 1967. p.391-403.

JANSSON, R.K. E SMILOWITZ, Z. Influence of nitrogen on population parameters of potato insects: abundance, development, and damage of the Colocado Potato Beetle, Leptinotarsa decemlineata (Coleoptera: Chrysomelidae). Environ. Entomol.. College Park, 14(4): $500-6,1985$.

JANSSON, R.K. \& SMILOWITZ, Z. Influence of nitrogen on population parameters of potato insects: abundance, population growth, and within - plant distribution of the Green Peach Aphid, Myzus persicae (Homoptera: Aphididae). Environ. Entomol.. College Park, 15(1): 49-55, 1986. 
KASTEN JR, P.; PRECETTI, A.A.C.M. \& PARRA, J.R.P. Dados biológicos comparativos de Spodoptera frugiperda (J.E. Smith, 1797) em duas dietas artificiais e substrato natural. Rev. Agric.. Piracicaba, 53(1-2): 68-78, 1978.

KOGAN, M. The role of chemical factors in insect/plant relationship. In: INTERNAT IONAL CONGRESS OF ENTOMOLOGY, 15, Washington, 1976. Proceddings, Washington, 1976. p.21127.

KOGAN, M. E PARRA, J.R.P. Techniques and aplications of measurements of consumption and utilization of food by phytophagous insetcs. In: BHASKARAN, G.; FRIDMAN, S. E RODRIGUEZ, J.G. eds. Current topics in insect endrocrinology and nutrition. New York, Plenum Publishing Corporation, 1981 . p. 377-52.

LABRADOR, S.J.R. Estudio de biologia y combate del gusano cogollero del maiz Laphygma frugiperda SEA. Maracaibo, Secc. Ent. Univ. Zulia, Venezuela, 1967. 83 p.

LARA, F.M. Princípios de Resistência de plantas a Insetos. Piracicaba, Livroceres, 1979. p.105-43.

LEIDERMAN, L. E SAUER, H.F.G. A lagarta dos milharais Laphygma frugiperda (Abbot e Smith, 1797). Biológico, São Paulo, 19(6): 105-13, 1953.

LEUCK, D.B. Induced fall armyworm resistance in pearl millet. J. Econ. Entomol. College Park, 65(6): 1608-11, 1972.

LEUCK, D.B. E HAMMONS, R.P. Nutrients and growth media: influence on expression of resistance to the Fall Armyworm in the peanut. J.Econ. Entomol. College Park, 67 (4): 564, $1974 \mathrm{a}$. 
LEUCK, D.B. \& HAMMONS, R. 0. Nutrient foliar sprays. Effect on insect resistance by the peanut. J.Econ. Entomol. Col lege Park, 67(4): 565, 1974b.

LEUCK, D.B.; WISEMAN, B.R. \& MCMILLIAN, W. W. Nutritional plant sprays: Effect on fall armyworm feeding preferences. J. Econ. Entomol. College Park, 67(1): 58-60, 1974.

LUBUS, C.A.F.; MENDES, E.; CALAFIORI, M.H. \& TEIXEIRA, N.T. Influência do nível de molibdênio e enxofre na população de tripes em amendoim (Arachis hypogaea, L.). Ecossistema. Pinhal, 9: $75-83,1984$.

LUCCHINI, F. Biologia da spodoptera frugiperda (smith e Abbot, 1797) (Lepidoptera, Noctuidae). Niveis de prejuizos e avaliação toxicológica de inseticidas para seu combate em milho. Curitiba, 1977. 114p. (Mestrado - Universidade Federal do Paranä).

LUGINBILL, P. The fall armyworm. USDA. Tech. Bull., Washington, n. $34,1928.92 p$.

LYNCH, R.E. Effects of 'Coastal' Bermudagrass fertilization levels and age of regrowth on Fall Armyworm (Lepidoptera: Noctuidae): Larval biology and adult fecundity. J. Econ. Entomol.. College Park, 77(4): 948-53, 1984.

MARTINS, J.F.S.; PINHEIRO, B.S. E LOWE, J.A. Nitrogênio e infestação da broca-do-colmo em arroz irrigado. Pesq. Agropec. Bras.. Brastilia, 13(3): 23-5, 1978.

MATTSON JR, W.J. Spruce budworm (Choristoneura fumiferana) performance in relation to foliar chemistry of host plants. Proceedings forest desfoliator - host interactions: a comparison between gypsy moth and spruce budworms. U.S. Dept. Agric. for Serv. Tech. Rep. NE-85, Saint Paul, 1983. 
MAXWELL, F.G. Host plant resistance to insects - nutritional and pest management relationships. In: RODRIGUEZ, J.G. Insect and mite nutrition. Netherlands, North Holland Publ. Comp., 1972. p.599-609.

MENSCHOY, A.B. Pragas do milho, métodos de defesa. Bol. Téc. Inst. Agron. Sul. Pelotas, 16: 1-8, 1956.

METCALF, C.L.; FLINT, W.P. E METCALF, R.L. Destructive and useful insects - their habits and control. 4.ed. New York McGraw-Hi11, 1962. 1087p.

MCNEILL, S. \& SOUTHWOOD, T.R.E. The role of nitrogen in the development of insect/plant relationships. In: HARBONE, J.B., ed. Biochemical aspects of plant and animal coevolu tion. New York, Academic Press, 1978. p.77-98.

NAKANO, 0. E ZUCCHI, R.A. Novos métodos de controle a Spocoptera frugiperda (J.E. Smith, 1797) em cultura de milho. 0 Solo, Piracicaba, $62(2): 23-6,197.0$.

PARRA, J.R.P. Biologia dos insetos. Piracicaba, ESALQ, 1979. $383 \mathrm{p}$. (mimeo).

PARRA, J.R.P. Métodos para medir consumo e utilização de ali mentos por insetos. In: RAMIRO, Z.A.; GRACIA, J. \& LARA, F.M. eds. CONGRESSO BRASILEIRO DE ENTOMOLOGIA, 6, Cam pinas, 1980. Anais. Campinas, Fund. Cargil1, 1980. p.77102 .

PARRA, J.R.P. E CARVALHO, S.M. de. Biologia e nutrição quantitativa de Spodoptera frugiperada (J.E. Smith, 1797) em meios artificiais compostos de diferentes variedades de feijão. An. Soc. Entomol. Brasil.. Porto Alegre, 12 (2): 305-319, 1984 . 
PATEL, P.N. \& HABIB, M.G.M. ocorrência natural de AspergilZus parasiticus em populações de Spodoptera frugiperda (A bot \& Smith, 1797) (Lepidoptera: Noctuidae) e sua transmis são por insetos parasitos. Rev. Agric. Piracicaba, (4): $223-32,1982$.

PEDRASI, T.C. E PARRA, J.R.P. Técnicas de criação e determinação das exigências térmicas de Telenomus remus Nixon (Hymenoptera, Scelionidae). In: CONGRESSO BRASILEIRO DE ENTOMOLOGIA, 10, Rio de Janeiro, 1986. Resumos. Rio de Janeiro, 1986. p. 207.

PEREYRA, E.M.M. de A. Aspecto da biologia de Archytas incertus (Mac Quart, 1851) (Diptera - Tachinidae) e suas interrelações com spodoptera frugiperda (J.E. Smith, 1797) (Le pidoptera - Noctuidae). Piracicaba, 1986.144p. (Doutorado - Escola Superior de Agricultura "Luiz de Queiroz"/ USP).

PERKINS, W.D.; JONES, R.L.; SPARKS, A.N.; WISEMAN, D.R.; SSNOW, J.W. E MCMILLIAN, W.W. Artificial diet for mass rearing of corn earworm (Heliothis zea). ARS-USDA,Prod. Res. Report n. 154, 1973. $7 p$.

PFEIFFER, D.G. E BURTS, E.C. Effect of tree fertilization on numbers and development of Pear Psylla (Homoptera: Psilli dae) and on fruit damage. Environ. Entomol. College Park, $12(3): 895-901,1983$.

PRATT, J.J.; HOUSE, H.L. E MANSINGH, A. Insect control strategies based on nutritional principles: a prospectus. In: RODRIGUEZ, J.G. ed. Insect and Mite Nutrition, Netherlands, North-Holland Publ. Comp., 1972. p.651-68. 
RAIJ, B. Van; SILVA, N.M. da; BATAGLIA, O.C.; QUAGGIO, J.A.; HIROCE, R.; CANTARELLA, H.; BELLINAZZI Jr.; R. DECHEN,A.R. E TRAN1, P.E. Recomendaçōes de adubação e calagem para o Es tado de São Paulo. Boletim Téćnico, Campinas, n. 100, 1985. 107p.

REIS, L.L.; OLIVEIRA, L.J. E CRUZ, I. Biologia e potencial de Doru iuteipes (Scudder, 1794) no controle de Spodoptera fruci perda. In: CONGRESSO NACIONAL DE MILHO E SORGO, 14, Maceió, 1984. Resumos. Maceió, 1984. p.113.

SCHOONHOVEN, L.M. Some aspects of host selection and feeding in phytophagous insects. In: RODRIGUEZ, J.G., ed. Insect and mite nutrition. Netherlands, North-Holland Publs. Comp., 1972. p.557-66.

SCRIBER, J.M. Sequential diets, metabolic costs, and growth of Spodoptera eridania (Lepidoptera, Noctuidae) feeding upon Dill, Lima Bean and Cabbage. Oecologia, Berlin, 51: $175-180,1981$.

SCRIBER, J.M. E SLANSKY JR., F: The nutritional ecology of immature insects. Ann. Rev. Entomol., Stanford, 26: $183-$ 211,1981 .

SCRIBER, J.M. The behavior and nutritional physiology of southern armyworm larvae as a function of plant species consumed in earlier instar. Ent. Exp. E Appl. Amsterdam, 31: $359-69,1982$.

SELL, D.K. E BODZNICK, D.A. Effects of dietary $\mathrm{ZnSO}_{4}$ on the growth and feeding of the Tobacco Budworm, Heliothis virescens. Ann. Entomol. Soc. Amer.. College Park, 64 (4): $850-5,1971$.

SGRILLO, R.B. A distribuif̧ão de Weibull como modelo de sobre vivência de insetos. Ecossistema. Pinhal, I: 9-13, 1982.

SHARMA, M.L. Rēponse des insectes phytophages aux traitments d'azote, potasse et phosphore appliqués aux plants. Ann. Soc. Entomol., 15(2): $88-95,1970$. 
SHAW, G.G. E LITTLE, C.H.A. Effect of high urea fertilization of balsam fir trees on spruce budworm development. In: RODRIGUEZ, J.G., ed. Insect and mite nutrition. North-Hol land Publ. Comp., Netherlands, 1972. p.589-97.

SILVEIRA NETO, S.; NAKANO, O.; BARBIN, D. \& VILLA NOVA, N.A. Manual de ecologia dos insetos. São Paulo, Ceres, 1976. $419 p$.

SLANSKY JR., F. Insect nutrition: An adaptationist's pers pective. Fla. Entomol. Gainesville, 65(1): 45-71, 1982.

SLANSKY JR., F. E SCRIBER, J.M. Food consumption and utilization. In: KERKUT, G.A. E GILBERT, L.I. eds Comprehen sive insect physiology biochemistry and pharmacology. New York, Pergamon Press, 1985. p.87-163.

SMITH, J.E. Phalaena frugiperda. In: ABBOT, J. E SMITH, J. E. The natural history of the rarer lepidopterous insects of Georgia. London, 1797. p.191-2.

SMITH, R.C. Observations on the fall armyworm (Laphugma frugiperda $S \& A)$ and some control experiments. J. Econ. Entomol. College Park, 14: 300-5, 1921.

SOD HOO, C.F. E FRAENKEL, G. The consumption, digestion and utilization of food plants by a polyphagous insect Prodenia eridania (cramer). J.Ins. Physiol. London, $12: 711$ $730,1966$.

SPARKS, A.N. A review of the biology of the fall armyworm. Fla. Entomol. Gainesville, 62(2): $82-7,1979$.

TANDON, H.L.S. The crop nutrition-pest incidence complex in India. PANS. London, 19(3): $372-80,1973$. 
TAYLOR, L.F.; APPLE, J.W. E BERGER, K.C. Response of certain insects to plants grown on varying fertility levels. J. Econ. Entomol. College Park, 45(5): 843-8, 1952 .

TINGEY, W.M. E SINGH, S.R. Environmental factors influencing the magnitude and expression of resistance. In: MAXWELL, F.G. E JENNINGS, P.R. Bredding plants resistant to insects. New York, Wiley-Interscience, 1980-p.87-113.

TOOD, E.L. E POOLE, R.W. Keys and illustrations for the armyworm moths of the noctuid genus Spodoptera Guenee from the Western Hemisphere. Ann. Entomol. Soc. Am.. College Park, 73: $722-38,1980$.

VALICENTE, F.H. Coleta e identificação dos parasitas das principais pragas de milho. In: CONGRESSO BRASILEIRO DE ENTOMOLOGIA, 10, Rio de Janeiro, 1986. Resumos. Rio de Janeiro, 1986a. p.237.

VALICENTE, F.H. Ocorréncia de nematóides mermitídeos em lagartas de Spodoptera frugiperda (J.E. Smith, 1797) (Lepidoptera: Noctuidae) em Sete Lagoas, MG. An. Soc. Entomol. Brasil. Porto Alegre, 15(2): 393-5, 1986 b.

VALICENTE, F.H.; PEIXOTO, M.J.V.V.D.; PAIVA, E. E KITAJIMA, E.W. Identificação e purificação de um virus de granulose em Spodoptera frugiperda (Lepidoptera, Noctuidae). In: CONGRESSO NACIONAL DE MILHO E SORGO, 15, Belo Horizonte, 1986. Resumos. Belo Horizonte, 1986. p.47-48.

VELEZ, C.M. \& SIFUENTES, J.A. El gusano cogollero de maiz; su combate con insecticidas granulados en el valle Apatzingan, Midi. Agric. Tec. Mex.. Chapingo, $2(7): \quad 315-7$, 1967 .

VETTORI, L. Métodos de anälise do solo. Rio de Janeiro, Equi pe de Pedologia e Fertilidade do Solo, Boletim Técnico $n$. 7., 1969. $34 \mathrm{p}$. 
VICKERY, R.A. Studies on the fall armyworm in the gulf coast district of Texas. Tech. Bull. Texas, n. 138, 1929.63p.

WALDBAUER, G.P. The consumption and utilization of food on insects. Advances in insect physiology. London, 5 : 22988,1968 .

WAQUIL, J.M.; VIANA, P.A.; LORDELLO, A.1.; CRUZ, I. E OLIVEIRA, A.C. Controle da lagarta-do-cartucho do milho com inseticidas químicos e biológicos. Pesq. Agropec. Bras. Brasilia, 17(2): $163-6,1982$.

WHITE, T.C.R. The importance of a relative shortage of food in animal ecology. Oecologia. Berlin, 33: 71-86, 1978.

WHITTAKER, R.H. E FEENEY, P.P. Alle.lochemics: chemical interactions between species. Science. Lancaster, 171:75770,1971 .

WISEMAN, B.R.; LEUCK, D.B. E MCMILLIAN, W.W. Effect of crop fertilizer on feeding of larvae of fall armyworm on exeised leaf sections of corn foliage. J. Ga. Entomol. Soc., $8(2): 136-41,1973 a$.

WISEMAN, B.R.; LEUCK, D.B. E MCMILLIAN, W.W. Increasing susceptibility and resistance of and intermediate resistant Antiqua corn to fall armyworm and corn earwor larval by fertilizer treatments. Fla. Entomol. Gainesville, 56: $1-7,1973 b$.

WISEMAN, B.R.; PAINTER, R.A. E WASSON, C.E. Detecting corn seedlinr srences in the greenhouse by visualclass fication of camage by the fall armyworm. J. Econ. Entomol. College Park, 59(5): 1211-14, 1966. 